\title{
Patricia Arashiro
}

\section{Estudo do perfil de expressão gênica na distrofia muscular fácio-escápulo-umeral (FSH)}

São Paulo

2009 


\section{Patricia Arashiro}

\section{Estudo do perfil de expressão gênica na distrofia muscular fácio-escápulo-umeral (FSH)}

Tese apresentada ao Instituto de Biociências da Universidade de São Paulo, para a obtenção de Título de Doutor em Ciências, na Área de Biologia/Genética.

Orientador(a): Dra. Mayana Zatz

São Paulo 


\section{ABREVIATURAS}

ATP - Adenosina trifosfato

ChIP - Imunoprecipitação da cromatina

DM - Distrofia muscular miotônica

EDMD - Distrofia muscular de Emery-Dreifuss

EDTA - Ácido etilenodiamino tetra-acético

FISH - Hibridização in situ por fluorescência

FSH ou FSHD - Distrofia muscular fácio-escápulo-umeral

GPI - glicosilfosfatidilinositol

IFN - interferon

IVT - transcrição in vitro

MAMI - "MetA Mir:target Inference"

miRNA ou miR - microRNA

PCR - Reação em cadeia de polimerase

PEV - variegação do efeito de posição

PFGE - Eletroforese em gel de campo pulsado

rpm - rotações por minuto

RT-PCR - Real-time PCR

SAPE - "Streptavidin Phycoerythrin"

SDS - dodecil sulfato de sódio

S/MAR - Região associada à matriz nuclear

SNP - "Single-Nucleotide Polymorphism"

SSLP - "Simple Sequence-Length Polymorphism" 


\section{CAPÍTULO I}

\section{I-INTRODUÇÃO}

\section{I.1. Características Clínicas}

A distrofia muscular fácio-escápulo-umeral (FSH) possui um padrão de herança autossômica dominante e é a terceira forma de distrofia muscular hereditária mais comum após as distrofias de Duchenne e miotônica (Emery, 1991). Como o próprio nome diz, ela é geralmente caracterizada inicialmente por uma fraqueza e atrofia da musculatura da face, da cintura escapular e do antebraço.

FSH foi inicialmente descrita por dois médicos franceses, Louis Landouzy e Joseph Dejerine, em 1885 (Landouzy \& Dejerine, 1885) após monitorar uma família por 11 anos (Rogers, 2004a). Uma grande variabilidade inter e intrafamilial está sempre presente nas descrições clínicas de FSH. Entretanto, apesar de haver uma grande variabilidade na progressão e no grau de fraqueza muscular, o modo como a doença se inicia e a sequiência dos músculos afetados é muito característica. Após avaliar 107 pacientes, Padberg (1982) descreveu que como primeiro sintoma da doença, 82\% dos pacientes notaram uma fraqueza na musculatura da cintura escapular, $10 \%$ dos pacientes notaram uma fraqueza na musculatura da face e $8 \%$ perceberam uma fraqueza na musculatura dos tornozelos. No exame clínico, no entanto, 94\% dos pacientes tinham fraqueza na musculatura facial, 93\% tinham fraqueza na cintura escapular, 67\% tinham fraqueza na musculatura dos tornozelos e 50\% tinham fraqueza na cintura pélvica.

Após o surgimento do diagnóstico molecular (ver I.2.4.), observou-se uma maior variabilidade do quadro-clínico. 


\section{I.1.1. Fraqueza da musculatura facial}

Os músculos da face mais freqüentemente afetados são o "orbicularis oculi" e o “orbicularis oris", com a presença de grande assimetria, característica marcante de FSH. A fraqueza da musculatura facial pode ser observada pela incapacidade do paciente em fechar os olhos com força e também pelo sorriso assimétrico, dificuldade em fazer um bico com os lábios, assoprar ou assobiar (Padberg, 1982). Esta dificuldade para sorrir constitui o principal entrave social que os pacientes com FSH enfrentam. A fraqueza na musculatura dos lábios pode levar a dificuldades de articulação em estágios mais avançados da doença (Pandya, 2008).

Wohlgemuth e cols. (2006) mostraram que 10 dos 87 pacientes adultos apresentam dificuldades de deglutição.

\section{I.1.2. Fraqueza da musculatura da cintura escapular}

Uma outra característica marcante dos pacientes é a posição mais elevada da escápula (escápula alada) devida à fraqueza dos músculos que fixam a escápula somada à relativa integridade do deltóide. Isso acaba refletindo na dificuldade que os pacientes apresentam para elevar os braços. Atrofia dos peitorais também é um dos primeiros sintomas da doença (Tyler, 1950).

\section{I.1.3. Fraqueza da musculatura abdominal}

A fraqueza da musculatura abdominal é uma outra característica que pode estar presente logo no início da doença. Esta fraqueza pode ser observada pela lordose presente em muitos pacientes (Padberg, 1982). Alguns estudos têm mostrado que a maioria dos pacientes com FSH apresenta sinal de Beevor (Shahrizaila e cols., 2005; Awerbuch e cols., 1990), no qual o umbigo é projetado para cima com a flexão do pescoço. 


\section{I.1.4. Fraqueza da musculatura dos membros inferiores}

Os músculos dos membros inferiores, como os extensores do pé e os da cintura pélvica também podem ser afetados pela doença (Padberg, 1982). Olsen e cols. (2006) viram que os músculos dos membros inferiores mais afetados nos pacientes com FSH são os do compartimento posterior, tibial anterior e o gastrocnêmio. $\mathrm{O}$ envolvimento dos membros inferiores é comum, sendo que cerca de $20 \%$ dos pacientes passam a utilizar cadeira de rodas (Lunt e cols., 1995a). A maioria dos pacientes apresenta, primeiramente, envolvimento dos membros superiores. Entretanto, em alguns casos, a fraqueza pode se iniciar pelos membros inferiores, e esporadicamente pode não ocorrer envolvimento facial. Dessa forma, não é raro o diagnóstico ser o de distrofia escápulo-peroneal ou atrofia escápulo-peroneal.

\section{I.1.5. Assimetria}

A assimetria do envolvimento muscular é uma característica presente nos pacientes com FSH. Várias hipóteses têm surgido para tentar explicar a causa desta assimetria, como a influência do paciente ser destro ou canhoto (Brouwer e cols., 1992), o excesso de atividade física (Johnson \& Braddon, 1971), ou se a assimetria faz mesmo parte de um processo intrínseco da doença (Thomas e cols., 2007) ou do mecanismo molecular (Padberg, 2004). Apesar da assimetria ser comum em FSH, a incidência de contraturas no tornozelo (10\%) e escoliose (30\%) não é alta entre os pacientes (Padberg, 2004).

\section{I.1.6. Envolvimento Cardíaco e Pulmonar}

Existem alguns estudos associando casos de pacientes de FSH gravemente afetados com a insuficiência respiratória (Howard e cols., 1993; Nakagawa e cols., 1997; Yasukohchi e cols., 1988). Um estudo realizado na população holandesa mostrou que aproximadamente $1 \%$ dos pacientes de FSH na Holanda utilizam algum suporte ventilatório (Wohlgemuth e cols., 2004). Nesse mesmo estudo eles identificaram que 
pacientes gravemente afetados em cadeira de rodas com escoliose e hiperlordose estão mais propensos a depender desses suportes (Wohlgemuth e cols., 2004). "Pectus excavatum" também é considerado um outro fator de risco para a insuficiência respiratória, que geralmente se inicia tarde durante o curso da doença (Wohlgemuth e cols., 2004). Em outro estudo, no qual foram comparados 24 pacientes com 24 controles normais, observou-se um envolvimento cardíaco entre os pacientes com FSH (Galetta e cols., 2005). Recentemente foi descrito o caso de um paciente com FSH que desenvolveu cardiomiopatia hipertrófica, comprovada por biópsia, antes do início da fraqueza dos músculos esqueléticos (Tsuji e cols., 2009).

\section{I.1.7. Progressão}

Aproximadamente 30\% de todos os casos familiais de FSH não progridem além da fraqueza da cintura escapular (Padberg, 1982). Nos casos restantes, $80 \%$ progridem até a fraqueza dos músculos extensores do pé e os outros $20 \%$ até a fraqueza da cintura pélvica. Nos membros superiores, a fraqueza progride atingindo o bíceps e o tríceps. Às vezes, os músculos extensores do pulso também são envolvidos, trazendo algumas limitações nas atividades manuais.

Os pacientes com FSH apresentam uma expectativa de vida normal, embora $20 \%$ ficam gravemente debilitados devido à fraqueza. Em geral, a progressão da doença é lenta, o que permite que os pacientes se adaptem e compensem a fraqueza para continuarem com as suas atividades.

\section{I.1.8. Outras características clínicas}

Dentre as outras características associadas a FSH estão: deficiência auditiva, retinopatia, dor, depressão, fadiga e em casos mais graves retardo mental (Brouwer e cols., 1995, 1991; Felice e cols., 2001, 2000; Funakoshi e cols., 1998; Miura e cols., 1998; van der Kooi e cols., 2000).

A deficiência auditiva em FSH inicia-se com a falta de percepção a sons agudos e pode progredir envolvendo todas as frequiências (Brouwer e cols., 1991). Retinopatia 
também tem sido associada a FSH (Padberg e cols., 1995). A perda da visão ocorre em apenas uma pequena parcela dos pacientes, mas a perda da audição a sons agudos tem sido descrita em 25\% a 65\% dos pacientes (Padberg, 2004; Padberg e cols., 1995).

Em um estudo com 109 pacientes com FSH realizado na Holanda, 74\% referem dor por mais de 4 dias por mês, e 58\% mais de 4 dias por semana (Koetsier, 1997). Nesse estudo (Koetsier, 1997), 91\% atribuíram a dor ao esforço físico e 74\% à postura incorreta devida à fraqueza muscular. A temperatura ambiente (48\%) e a umidade do ar (27\%) também tinham influências nas queixas relacionadas a dor. Em um outro estudo, foi mostrado que $82 \%$ dos pacientes com FSH, contra $64 \%$ dos pacientes com distrofia miotônica, apresentam dor (Jensen e cols., 2008). As regiões com mais queixas são a lombar inferior (66\% em miotônica, $74 \%$ em FSH) e as pernas (60\% em miotônica, $72 \%$ em FSH) (Jensen e cols., 2008).

Bushby e cols. (1998) mostraram relatos de pacientes com FSH que descreveram uma sensação de frustração, simultaneamente à depressão e irritabilidade, aliviadas com a administração de antidepressivos. Em um outro estudo foram avaliados 79 pacientes com distrofia miotônica e 65 com FSH, no qual 10-12\% dos pacientes apresentavam igualmente algum distúrbio psiquiátrico. Os distúrbios mais comuns eram depressão e fobias, e não estavam associados à fadiga ou à força muscular (Kalkman e cols., 2007). Anteriormente, este mesmo grupo mostrou que dos 139 pacientes com FSH, 61\% apresentavam uma fadiga grave, com uma atividade física reduzida e baixa motivação (Kalkman e cols., 2005).

Casos graves de FSH podem raramente envolver também retardo mental e epilepsia (Matsuzaka e cols., 1986; Funakoshi e cols., 1998; Miura e cols., 1998). Saito e cols. (2007) descreveram o caso de uma paciente de FSH gravemente afetada com 20 anos de idade, que apresenta um retardo mental profundo, epilepsia e uma certa deficiência auditiva. Como os pacientes que apresentam epilepsia e retardo mental são gravemente afetados, é possível que eles constituam um grupo distinto dentro de FSH ou então que representem o extremo de um espectro clínico. No último caso, pequenas mudanças no funcionamento do sistema nervoso central deveriam ser detectadas nos pacientes com a forma clássica (Di Lazzaro e cols., 2004). Para investigar esta hipótese, foi examinada a excitabilidade do córtex motor em 20 pacientes com FSH clinicamente 
heterogêneos, comparando-os com 20 indivíduos saudáveis e seis pacientes com outras distrofias musculares. Os resultados mostraram diminuição da inibição cortical, uma alteração comum em casos de epilepsia, nos pacientes com FSH quando comparados aos controles e aos pacientes com outras distrofias, enquanto que estes não diferiram dos controles saudáveis (Di Lazzaro e cols., 2004).

\section{I.1.9. Formas infantis e de início precoce}

Embora a maioria dos pacientes com FSH apresenta os sinais clínicos aos 20-30 anos de idade, há casos de formas infantis ou de início precoce descritos (Brooke, 1977; Carroll \& Brooke, 1979; Klinge e cols., 2006; Kriwalsky e cols., 2008). Em geral a forma infantil é definida como a presença de sinais ou sintomas de fraqueza facial antes dos cinco anos de idade e sinais ou sintomas de fraqueza da cintura escapular antes dos 10 anos de idade (Brouwer e cols., 1994). Estima-se que a incidência desses casos seja por volta de $4 \%$ da população total de FSH (adultos e crianças), sendo que $58 \%$ da população de FSH têm menos de 18 anos (Brouwer e cols., 1994). A maioria desses pacientes é de caso esporádico, que devida à apresentação clínica, não é incomum que eles sejam diagnosticados com a síndrome Möbius (Klinge e cols., 2006). Um estudo do Japão tem associado retardo mental e epilepsia a pacientes com início precoce que são gravemente afetados (Funakoshi e cols., 1998).

\section{I.1.10. Variabilidade Clínica e os Portadores Assintomáticos}

Indivíduos com FSH podem apresentar uma grande variabilidade no quadro clínico, em que os sintomas mais graves aparecem logo na infância ou aparecem de forma mais branda, podendo até mesmo nem aparecer na fase adulta, o que caracteriza os portadores assintomáticos. Esta variabilidade clínica pode ser tanto inter como intrafamilial. Além disso, diversos estudos indicam que as mulheres geralmente apresentam um quadro-clínico mais brando do que os homens (Padberg, 1982; Lunt e cols., 1989; Padberg e cols., 1995; Zatz e cols., 1998). Em um outro estudo, levando-se em consideração a idade de início dos primeiros sinais clínicos e a idade de averiguação, 
foi possível observar a antecipação na maioria das famílias com portadores de FSH (Zatz e cols., 1995).

\section{I.1.11. Características histológicas do músculo}

As biópsias de músculo dos pacientes de FSH não demonstram nenhuma característica morfológica específica da doença e também são bastante variáveis, dependendo do estágio da doença e do local da biópsia (Kissel, 1999; Rogers e col., 2004b). Estas biópsias apresentam características distróficas, como aumento da variação do tipo de fibra e calibre (Rogers e col., 2004b), necrose, fibrose e centralização nuclear. As fibras "moth-eaten" e as angulares são freqüentemente vistas, indicando regeneração (Arahata e col., 1995; Padberg, 1998, 1997; Rogers e col., 2004b). Células mononucleares inflamatórias com aumento de necrose têm sido detectadas em até $40 \%$ dos pacientes de FSH. O mecanismo causador destes infiltrados e a sua significância são ainda desconhecidos (Arahata e col., 1995; Felice e col, 2000; Kissel, 1999; Padberg, 1982).

\section{I.2. Fatores Genéticos e Moleculares}

\section{I.2.1. Penetrância}

Em um estudo conduzido no Reino Unido, estimou-se a penetrância de FSH como: $<5 \%$ de $0-4$ anos, $21 \%$ de $5-9$ anos, $58 \%$ de $10-14$ anos, $86 \%$ de $15-19$ anos e $95 \%$ para acima de 20 anos (Lunt e cols., 1989).

Um estudo envolvendo 53 famílias brasileiras com FSH mostrou uma diferença significativa entre homens e mulheres. A penetrância em homens de 30 anos foi estimada em $95 \%$, enquanto que em mulheres da mesma idade a penetrância foi estimada em apenas 69\%, resultando em uma penetrância total de $83 \%$ aos 30 anos (Zatz e cols., 1998). 
Posteriormente, em um estudo conduzido com 85 pacientes japoneses, a análise molecular mostrou que 35 (41\%) eram casos esporádicos, enquanto que 26/50 (52\%) dos pais que apresentavam o alelo contraído (ver I.2.4.) não apresentavam nenhum sinal clínico (Goto e cols., 2004). Este estudo sugeriu então que a penetrância em FSH é menor do que a estimada anteriormente, sendo em torno de 59\% na idade adulta (Goto e cols., 2004).

\section{I.2.2. Mapeamento do loco de FSH}

Em 1990, através do estudo de ligação em 10 famílias holandesas utilizando marcadores de microssatélites foi mapeado o principal loco de FSH (FSHD1) no cromossomo 4 (Wijmenga e cols., 1990). Outros estudos foram realizados para refinar a região mapeada e foi encontrada uma ligação com o marcador pH30 (Upadhyaya e cols, 1990, 1991; Wijmenga e cols, 1991). Este marcador corresponde ao loco D4S139 que foi mapeado na região 4q35-4qtel por estudo de ligação (Milner e cols., 1989) e por hibridização in situ por fluorescência (FISH) (Wijmenga e cols., 1991). Estudos posteriores confirmaram a ligação de FSH a 4q35-4qtel (Upadhyaya e cols., 1990, 1991; Gilbert e cols., 1992; Mathews e cols., 1992; Weiffenbach e cols., 1992; Sarfarazi e cols., 1992). No entanto, há evidências para heterogeneidade genética em pelo menos $5 \%$ das famílias de FSH (Wijmenga e cols, 1991; Gilbert e cols., 1992, 1993; Bakker e cols., 1995). Até o momento nenhum outro loco para FSH foi identificado, embora haja

evidências para ligação no cromossomo 15 em duas famílias de FSH não-ligadas a 4q (Randolph-Anderson e cols., 2002).

Para tentar identificar os genes candidatos de FSH, foi construído em seguida o mapa físico da região distal a D4S139 (Wijmenga e cols., 1993a; Wright e cols., 1993). Utilizando enzimas de restrição e bibliotecas de YAC 25C2E foi possível construir um mapa físico detalhado da região de FSH. A partir deste mapa a região foi melhor caracterizada com o objetivo de tentar descobrir a causa genética de FSH. 


\section{I.2.3. Repetição D4Z4 em tandem}

Os dois marcadores mais distais de 4q35 - D4F10S1 (sonda p13E-11) e D4Z4 (unidade de repetição com $3.3 \mathrm{~kb}$ ) - foram isolados do cosmídeo 13E (Wijmenga e cols., 1992a). A sonda p13E-11, que se localiza 5kb proximal de D4Z4, detecta 2 locos polimórficos. Através da análise dos haplótipos, um dos locos foi atribuído ao cromossomo 4q35, correspondendo a D4Z4 (Wijmenga e cols, 1992a, 1994). O outro loco polimórfico foi posteriormente mapeado no cromossomo 10q26 (Bakker e cols., 1995; Deidda e cols., 1996). Em indivíduos normais, p13E-11 detecta fragmentos de EcoRI que podem variar de $38 \mathrm{~kb}$ até $300 \mathrm{~kb}$ (> 10 repetições) (Wijmenga e cols., 1992a). No entanto, em pacientes com FSH, p13E-11 detecta fragmentos de EcoRI que são menores de 38kb (< 10 repetições) (Wijmenga e cols., 1992a) (Figura 1). Wijmenga e cols (1992b) mostraram o caso de uma família holandesa, no qual o fragmento de EcoRI $<38 \mathrm{~kb}$ do probando foi herdado junto com a doença pelo seu filho, confirmando a associação entre o fragmento de EcoRI < 38kb detectado por p13E-11 e FSH. Nas famílias de FSH, observa-se que o mesmo fragmento pequeno de EcoRI segrega junto com a doença entre os afetados (Wijmenga e cols., 1992a; Passsos-Bueno e cols., 1993; Upadhyaya e cols., 1993; Weiffenbach e cols., 1993; Goto e cols., 1995; Bakker e cols., 1996).

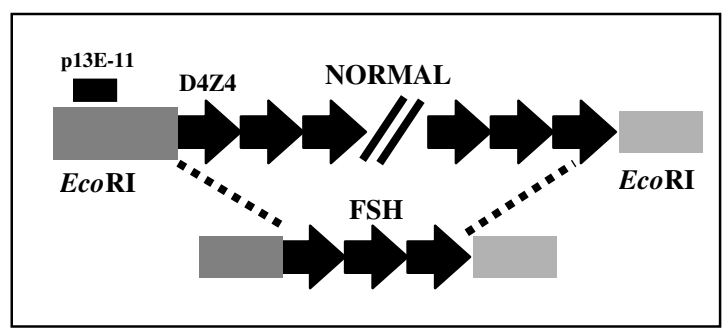

Figura 1. A análise dos fragmentos de EcoRI mostrou que FSH está associada a deleção do número de repetições de 3.3kb D4Z4 (van Deutekom, 1996a).

\section{I.2.4. Diagnóstico Molecular de FSH}

Com a associação de FSH à deleção do número de D4Z4, logo foi desenvolvido o diagnóstico molecular para FSH. Este método é baseado no "Southern blotting" do DNA 
genômico digerido com EcoRI seguido da hibridização com a sonda p13E-11 marcada com radioativo $\left[\alpha{ }^{32} \mathrm{P}\right]$ dCTP (Wijmenga e cols., 1992a).

Um dos fatores complicadores do diagnóstico é a grande homologia de 4q35 com o loco 10q26, fazendo com que a sonda p13E-11 tenha uma hibridização cruzada com a região das repetições do cromossomo 10. No total, a sonda p13E-11 reconhece quatro fragmentos polimórficos de EcoRI: dois derivados de 4q35 e dois derivados de 10q26, além do fragmento de 9,4kb do cromossomo Y. Estima-se que em $10 \%$ da população os fragmentos de 10q26 sejam menores que $38 \mathrm{~kb}$, mas sem consequiências patogênicas (Bakker e cols., 1995).

A identificação de um sítio de restrição para a enzima $B \ln \mathrm{I}$, presente apenas nas repetições D4Z4 do cromossomo 10, possibilitou a diferenciação entre repetições derivadas de 4q35 e 10q26 (Deidda e cols., 1996), melhorando consideravelmente o diagnóstico molecular de FSH (Upadhyaya e cols., 1997). Após a digestão dupla, apenas os fragmentos derivados de 4q35 são visíveis, enquanto os de 10q26 são clivados. Os fragmentos de EcoRI, que se mantêm após a digestão dupla e são menores que 38kb são considerados fragmentos de FSH (Figura 2).

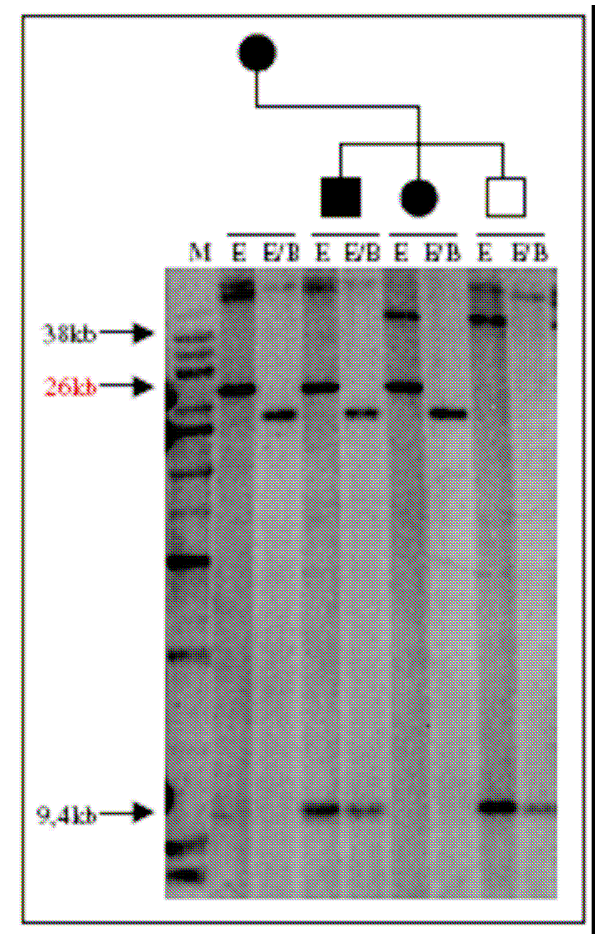

Figura 2. Amostras de DNA submetidas à dupla digestão com EcoRI (E) e EcoRI/BlnI (E/B) após hibridização com a sonda p13E-11. Os 3 pacientes afetados 
apresentam o fragmento de EcoRI contraído com $26 \mathrm{~kb}$ do cromossomo 4. Neste gel observa-se também que a sonda p13E-11 hibridiza com o fragmento de 9,4kb do cromossomo Y.

Um outro método desenvolvido para determinar o número de repetições de D4Z4 nos pacientes com o quadro-clínico de FSH é através do PCR de longo alcance, uma técnica mais rápida, que requer uma quantidade bem menor de DNA, mais barata e precisa do que o tradicional "Southern blotting" (Goto e cols., 2006). Utilizando primers específicos para o cromossomo 4q, esta técnica permite amplificar sequiências de até 5 repetições de D4Z4 $(18,4 \mathrm{~kb})$, sendo viável apenas para os casos familiais quando se sabe o número de repetições do alelo com a contração segregando na família.

Apesar das vantagens do PCR de longo alcance, a alta taxa de casos esporádicos (10\% - 30\%) (Zatz e cols., 1995) limita o uso desta técnica para diagnóstico de FSH. Além disso, Lemmers e cols. (2006) mostraram que esta técnica tem uma menor aplicação na população caucasiana, já que 54\% (222/407) dos pacientes com FSH apresentam o alelo contraído com 5-10 repetições, enquanto que os outros 46\% (185/407) apresentam o alelo ligado a FSH com menos de 5 repetições. Desta forma, pelo menos metade dos pacientes caucasianos com FSH não podem ser diagnosticados utilizando PCR (Lemmers e cols., 2006). Ao contrário, nos pacientes de FSH do Japão observa-se que é mais comum encontrar alelos com 1-5 repetições de D4Z4, sendo o PCR uma boa alternativa para genotipagem (Lemmers e cols., 2006).

Como as repetições de D4Z4 nos cromossomos 10q26 e 4q35 apresentam 98\% de identidade (Deidda e cols, 1995; van Geel e cols., 2002) é comum observar translocações entre estes dois locos (Matsumura e cols., 2002; Lemmers e cols., 1998). O estudo de DNA de controles por eletroforese em gel de campo pulsado (PFGE) mostrou repetições derivadas de 4q35 no cromossomo 10 e vice-versa em aproximadamente $20 \%$ da amostra (van Deutekom e cols., 1996b, van Overveld e cols., 2000). Estudos em outras populações mostraram que a proporção de translocações 4;10 versus 10;4 pode variar em diferentes grupos étnicos (Matsumura e cols., 2002). Embora seja freqüente, as contrações das repetições no cromossomo 10 não são patogênicas, mesmo se as repetições forem derivadas do cromossomo 4 (Lemmers e cols., 2001; Zhang e cols, 
2001). Buzhov e cols. (2005) e Lemmers e cols (2001) mostraram que com o uso adicional da enzima de restrição XapI é possível determinar a constituição dos alelos.

Cerca de 3\% dos pacientes de FSH apresentam deleção na região da sonda p13E11 (Lemmers e cols., 2003). Neste caso é mais difícil diagnosticar FSH, já que não é possível observar o alelo contraído utilizando a sonda p13E-11 e por PCR de longo alcance, uma vez que um dos primers anela na região desta sonda. Uma forma de se resolver este problema é através da hibridização com a sonda de $1 \mathrm{~kb}$ que anela no D4Z4 dos cromossomos 4 e 10 (Ehrlich e cols., 2007). Um outro método para identificar as deleções em p13E-11 é através da digestão com HindIII ao invés de EcoRI. Os fragmentos da digestão com HindIII são 6kb maiores que os da digestão com EcoRI e permitem o uso da sonda 4qA (ver I.2.8.2.) que reconhece uma seqüência distal à repetição D4Z4, além da sonda p13E-11 (Lemmers e cols., 2002).

Recentemente foi divulgado um kit para a realização do diagnóstico molecular de FSH (Walrafen e col., 2008). Através da técnica de "molecular combing", na qual a molécula de DNA é esticada sobre uma superfície, seguida de FISH, utilizando sondas específicas para 4q, D4Z4, qA, qB e 10q, é possível visualizar diretamente a posição das sondas nas moléculas de DNA, identificando os alelos 4qA-D4Z4 (ver I.2.8.2.) e distingui-los dos alelos 4qB-D4Z4 e 10q-D4Z4, bem como contar o número de repetições de D4Z4 diretamente (Walrafen e col., 2008). Este método permite a identificação de translocações, deleção na região proximal (p13E-11) e mosaicismo (ver I.2.5.), além de ser uma técnica mais rápida, exata e de não depender de material radioativo (Walrafen e col., 2008). No entanto, este kit ainda não está disponível comercialmente.

\section{I.2.5. Mosaicismo em FSH}

O termo mosaico pode ser definido como a condição no qual o indivíduo apresenta duas ou mais linhagens celulares geneticamente distintas e derivadas de um mesmo zigoto, que diferem em virtude da presença de uma mutação ou não-disjunção (Gelehrter e cols., 1998). Os eventos que induzem o mosaicismo podem influenciar no fenótipo tanto de forma negativa como positiva. O mosaicismo tem sido descrito em 
diversas doenças, como hemofilia, distrofia muscular de Duchenne, ataxia de Friedreich e FSH (Gottlieb e cols., 2001).

Weiffenbach e cols (1993) analisaram duas famílias com mosaicismo na linhagem germinativa. O exame clínico dos pais e dos filhos das duas famílias confirmou FSH nos filhos, mas os pais não apresentavam fraqueza nos músculos da face ou da cintura escapular. Nas duas famílias, o exame molecular utilizando DNA extraído do sangue periférico confirmou a presença da deleção em 4q35 nos filhos, mas não nos pais. Este resultado sugeriu que somente algumas ou talvez todas as células germinativas do pai ou da mãe apresentavam a mutação, e nenhuma célula somática (pelo menos não os leucócitos) era afetada. No mesmo ano, um outro estudo com observações semelhantes foi publicado (Griggs e cols, 1993). Posteriormente, em um estudo realizado no nosso centro, foi mostrado que a proporção de mosaicismo no sangue e no músculo é semelhante, sugerindo que a contração de D4Z4 ocorre nos primeiros estágios do desenvolvimento embrionário (Tonini e cols., 2006).

Cerca de $20 \%$ dos casos esporádicos de FSH são atribuídos ao mosaicismo (van der Maarel e col., 2000). A análise molecular é mais facilmente visualizada por eletroforese em gel de campo pulsado (PFGE), no qual o mosaicismo é observado como sendo uma quinta banda após a hibridização com a sonda p13E-11. A proporção de células com o alelo contraído varia de $15 \%$ a $95 \%$, com base na intensidade relativa do sinal (van der Maarel e col., 2000). Em geral, nas mulheres mosaicos, a proporção das células com a mutação era maior do que nos homens e, além disso, os homens mosaicos eram normalmente mais afetados do que as mulheres, sugerindo que as mulheres devem ter uma maior tolerância clínica do que os homens (van der Maarel e cols., 2000). Esta observação corrobora com estudos anteriores, já mencionados, que relatam que os homens normalmente são mais gravemente afetados do que as mulheres (Padberg, 1982; Lunt e cols., 1989; Padberg e cols., 1995; Zatz e cols., 1998).

\section{I.2.6. Correlação genótipo-fenótipo}

Como o tamanho do fragmento de EcoRI pode variar entre os pacientes de diferentes famílias, muitos estudos têm sido realizados comparando o efeito do tamanho 
do alelo contraído na gravidade do quadro-clínico. Comparações entre o número de repetições e a clínica do paciente mostraram que a idade de início e a gravidade do fenótipo nos probandos estão aproximadamente inversamente relacionados com o número residual de repetições (Arahata e col, 1998; Attarian e col, 1998; Hsu e col, 1997; Köhler e col, 1999; Lunt e col., 1995b; Ricci e col., 1999; Tawil e col., 1996; Zatz e col., 1995). Pacientes gravemente afetados (normalmente crianças) com o envolvimento dos membros inferiores normalmente possuem fragmentos de $10-17 \mathrm{~kb}$, enquanto que pacientes que começam a manifestar os sintomas durante a adolescência costumam ter fragmentos de 18-30kb (Fitzsimons, 1999; Funakoshi e col, 1998; Lunt \& Harper, 1991; Lunt e col, 1995a, 1995b, 2000; Tonini e col, 2004). Desta forma, indivíduos com um quadro-clínico mais brando têm, em média, fragmentos maiores, enquanto que os gravemente afetados têm fragmentos menores (Fitzsimons, 1999; Lunt, 2000; Tonini e col, 2004). Pacientes com início precoce são, normalmente, casos graves esporádicos com fragmentos pequenos (Brouwer e col., 1995; Funakoshi e col, 1998; Jardine e col., 1994; Lunt e col., 1995a, 2004; Padberg, 2004). No entanto, fragmentos pequenos também podem ser encontrados em pacientes esporádicos com quadro-clínico brando ou mesmo portadores assintomáticos (Tonini e col, 2004; Wu e col, 2004). Por outro lado, pacientes com fragmentos maiores que 30kb também podem ter um quadro-clínico grave (Butz e col, 2003; Wu e col., 2004), o que mostra que o número de repetições não é o único fator modulando o fenótipo.

\section{I.2.7. Aconselhamento Genético (AG)}

Para o aconselhamento genético, é necessário que o consulente já tenha comprovado previamente o diagnóstico molecular para FSH (ver I.2.4.). Assuntos como o risco de recorrência de $50 \%$, a falta de um tratamento efetivo e de um prognóstico confiável para os que herdaram a mutação devem ser discutidos durante o AG (Eggers e cols, 1993).

Apesar de ser, em geral lenta, a FSH é uma doença progressiva. Desta forma, se o indivíduo não apresenta fraqueza nos membros inferiores aos 20 anos de idade, é pouco provável que ele necessite de cadeira de rodas aos 40-50 anos (Lunt e Harper, 1991). 
Pelo fato de, em média, as mulheres serem menos afetadas que os homens (Zatz e cols., 1998), a gravidade do quadro clínico de uma geração para outra tende a ser mais acentuada em filhos de mães afetadas do que nas filhas de pais afetados. No caso de mosaicismo, o fenótipo dos filhos normalmente é mais grave que o da geração anterior (van der Maarel e cols, 2000).

Durante a consulta, é discutida também a importância da fisioterapia e de trazer outros membros da família que têm risco de ter herdado a mutação (Eggers e cols, 1993).

\section{I.2.8. Outros estudos associados a FSH}

\section{I.2.8.1. $\quad 0$ gene $D U X 4$}

Com a associação de FSH com a contração de D4Z4, estas repetições passaram a ser o primeiro alvo para a procura do gene candidato de FSH. D4Z4 possui características de ilhas CpG, como um alto conteúdo de GC (71\%) com uma razão de CpG/GpC de 0,8 (Wijmenga e cols, 1993b;.Wright e cols., 1993). Dentro de cada repetição, um suposto gene com dois domínios "homeobox" foi descoberto, o qual foi chamado de DUX4 (“double homeobox 4") (Gabriëls e cols, 1999). DUX4 tem uma fase de leitura aberta (ORF) com 424 aminoácidos e é precedido por uma sequiência que apresenta uma forte atividade promotora em estudos de expressão.

Como D4Z4 era considerado de natureza heterocromática, surgiu a hipótese de que a deleção das repetições de D4Z4 resultaria na desestabilização da heterocromatina de D4Z4 e, por fim, na expressão do gene DUX4 (Hewitt e cols, 1994; Gabriëls e cols, 1999). O aumento da expressão de $D U X 4$ poderia induzir a morte celular por apoptose, induzir a ativação da caspase 3/7 e alterar a distribuição de emerina no envelope nuclear (Kowaljow e cols., 2007). Além disso, a expressão de DUX4 ativaria PITX1 ("paired-like homeodomain transcription factor 1"). Interessantemente, o aumento da expressão da proteína PITX1 também foi observada nas biópsias de músculo de pacientes com FSH (Kowaljow e cols., 2007; Dixit e cols, 2007). PITX é conhecido por afetar a simetria direita-esquerda (Dixit e cols, 2007). 
A funcionalidade do gene DUX4 é questionada há muito tempo, devida à falta de introns, de sinais de poliadenilação e a ausência da transcrição in vivo (Hewitt e cols, 1994; Gabriëls e cols, 1999; Winokur e cols, 2003; Osborne e cols, 2007; Alexiadis e cols, 2007). Recentemente, homólogos de D4Z4 foram identificados em várias espécies de mamíferos e foi demonstrado que a ORF de DUX4 está conservada evolutivamente. Isto colaca em dúvida a sua não-funcionalidade, sugerindo um papel codificante para DUX4, provavelmente durante o desenvolvimento (Clapp e cols, 2007).

\section{I.2.8.2. Polimorfismos em $4 \mathrm{q} 35$}

van Geel e cols (2002) identificaram duas variantes para a região subtelomérica do cromossomo 4q: "4qA" e "4qB". Posteriormente, foi mostrado que apesar destas duas variantes serem igualmente comuns na população, FSH está exclusivamente associada com a deleção de D4Z4 no alelo 4qA (Lemmers e cols, 2002). As deleções de D4Z4 no alelo 4qB não causam FSH (Lemmers e cols, 2004). A diferença entre estes dois alelos está na presença de uma região de $\beta$-satélite de $6,2 \mathrm{~kb}$ na região distal a D4Z4 nos alelos 4qA (van Geel e cols, 2002). Além destas duas variantes, um terceiro alelo, mais raro, foi identificado em alguns pacientes de FSH (Thomas e cols, 2007). Estudando mais dois polimorfismos no loco de FSH - "simple sequence-length polymorphism" localizado na região proximal a D4Z4 e um "single-nucleotide polymorphism" (SNP) localizado dentro de D4Z4 - o cromossomo 4q35 pôde ser subdividido em 9 haplótipos diferentes (Lemmers e cols, 2007). Apenas as deleções em um destes haplótipos, denominado "4qA161", está associado a FSH, enquanto que as deleções em outros haplótipos de 4q, como "4qA166" e "4qB163" não são patogênicas (Lemmers e cols, 2007). Não se sabe ainda o que determina a diferença na patogenicidade entre os diferentes haplótipos, mas acredita-se que alguns polimorfismos específicos em 4q35 devam ser essenciais para o desenvolvimento de FSH. 


\section{I.2.8.3. Metilação em FSH}

A metilação do DNA é uma modificação endógena no DNA comum entre os eucariotos (Costello \& Plass, 2001; Singal \& Ginder, 1999) e envolve a adição do grupo metila no carbono 5 do anel da citosina do nucleotídeo CpG (Bird, 1992; Singal \& Ginder, 1999). Embora outras sequiências também podem estar metiladas, quase toda metilação das citosinas nos eucariotos ocorre nas ilhas CpG (Attwood e cols, 2002; Costello \& Plass, 2001; Richardson, 2003). A presença dos grupos metila no DNA está normalmente associada com um aumento da condensação da cromatina e o silenciamento de genes. Quando a região promotora está metilada, fatores de transcrição que reconhecem os dinucleotídeos CpG não podem se ligar mais (Campanero e cols, 2000).

Como já foi dito anteriormente (ver I.2.8.1), D4Z4 apresenta características de ilhas CpG. O primeiro estudo sobre metilação em D4Z4 não mostrou uma diferença no nível de metilação entre as amostras de biópsia de músculo e as linhagens celulares dos controles e pacientes de FSH. No entanto, o nível de metilação das repetições de D4Z4 dos cromossomos 4 e 10 foram analisados simultaneamente (Tsien e cols, 2001). Posteriormente, ao diferenciar os cromossomos 4 e 10, foi observada uma significativa hipometilação no alelo contraído dos pacientes de FSH em relação aos controles (van Overveld e cols, 2003). Embora este estudo tenha sido realizado no DNA extraído do sangue periférico, um nível similar de hipometilação foi encontrado nas amostras de DNA isoladas de músculo de FSH. Interessantemente, a hipometilação também foi observada no alelo com a deleção de D4Z4 dos portadores assintomáticos e em ambos alelos do cromossomo 4 dos pacientes que têm o fenótipo de FSH, mas não apresentam a contração (van Overveld e cols, 2003). Em seguida, verificou-se que o nível de metilação varia substancialmente entre os indivíduos. Normalmente, pacientes com 10-20kb são gravemente afetados e apresentam um nível baixo de metilação, enquanto que os pacientes com 20-31 kb apresentam uma maior variabilidade tanto clínica quanto do nível de hipometilação (van Overveld e cols, 2005).

Em alguns tipos de câncer, observa-se a hipermetilação das repetições de D4Z4,

nas quais parte da região proximal parece ser mais resistente a metilação do DNA (Tsumagari e cols, 2008). Este resultado sugere a presença de um elemento na junção de 
D4Z4 e a região proximal rica em AT (Tsumagari e cols, 2008), que poderia ser essencial para separar fisicamente as regiões genômicas ativa e inativa (Zhou \& Berger, 2004).

\section{I.2.8.4. Modificações das histonas em FSH}

As histonas podem sofrer várias modificações pós-traducionais, como acetilação, metilação, fosforilação e ubiquitinação (Bhaumik e cols, 2007). As modificações nas histonas podem afetar diretamente a estrutura da cromatina, impedindo a ligação de fatores de transcrição, ou alterar as interações das caudas das histonas com o DNA (Peterson \& Laniel, 2004). Por outro lado, as modificações nas histonas podem ajudar na associação de proteínas com a cromatina. Como consequiência, outros eventos que alteram o estado da cromatina podem ocorrer (Strahl \& Allis, 2000). Algumas modificações específicas nas histonas podem estar associadas com a ativação da transcrição ou com a repressão da transcrição. Metilação nos resíduos da lisina 4, 36 e 79 da histona $\mathrm{H} 3$ tem sido relacionada com a ativação da transcrição. Acetilação dos resíduos da arginina das histonas H3 e H4 também é característica da ativação do gene (Eberharter \& Becker, 2002). No entanto, metilação nos resíduos da lisina 9 e 27 da histona $\mathrm{H} 3$ e no resíduo da lisina 20 da histona $\mathrm{H} 4$ têm sido associados com heterocromatina e repressão do gene (Fischle e col, 2003; Lachner e col, 2003).

Através da imunoprecipitação da cromatina (ChIP) e FISH, foi analisada a natureza das repetições de D4Z4. Comparando o nível de acetilação da histona H4 e de metilação nas lisinas 4 e 9 da histona $\mathrm{H3}$, concluiu-se que as repetições de D4Z4 apresentam mais uma estrutura de eucromatina não-expressa do que de heterocromatina constitutiva (Jiang e col, 2003; Yang e col, 2004).

\section{I.2.8.5. Outros genes em $4 \mathrm{q} 35$}

Poucos genes têm sido considerados como bons candidatos para FSH baseados na sua localização e função. O primeiro gene considerado candidato para FSH foi o ANT1, que codifica para um translocador do nucleotídeo adenina. Este gene está localizado a $3,5 \mathrm{Mb}$ de D4Z4 e o seu produto está envolvido no transporte de ATP na membrana 
mitocondrial (Doerner e cols, 1997; Li e cols, 1989; Stepien e cols, 1992). Como ANT1 é altamente expresso no músculo esquelético e está envolvido em algumas doenças neuromusculares, este gene foi considerado um bom candidato. No entanto há controvérsias a respeito da sua expressão aumentada nos músculos dos pacientes (Laoudj-Chenivesse e cols, 2005). Além disso, camundongos transgênicos que superexpressam ANT1 no músculo não desenvolvem distrofia muscular (Gabellini e col, 2006).

Um outro gene candidato foi o PDLIM3, que codifica para uma proteína LIM associada a actinina especificamente de músculo. No entanto, análises de "Western blotting" e imunohistoquímica não mostraram uma expressão alterada de PDLIM3 (Bouju e cols, 1999; Xia e cols, 1997). Camundongos "knockout" para PDLIM3 não demonstram sinais de distrofia muscular, o que diminui as chances de PDLIM3 estar envolvido em FSH (Pashmforoush e cols, 2001).

O gene mais próximo de D4Z4 é FRG2. FRG2 se localiza a 37kb de D4Z4 e codifica para uma proteína nuclear de função ainda desconhecida (Rijkers e col, 2004). Embora a sua expressão esteja especificamente aumentada nas células de músculo em diferenciação dos pacientes de FSH, a sua ausência em alguns pacientes que tem a região proximal de D4Z4 deletada, torna este gene pouco atrativo (Lemmers e col, 2003). Além disso, camundongos que superexpressam $F R G 2$ também não apresentam distrofia muscular (Gabellini e col, 2006).

O outro gene candidato, que está localizado a $120 \mathrm{~kb}$ de D4Z4, é o FRG1. Este gene está altamente conservado nos vertebrados e invertebrados e codifica para uma proteína nuclear. Há evidências de que FRG1 é uma proteína do spliceossomo, mas a sua função exata ainda não é conhecida (Grewal e col, 1998; van Deutekom e col, 1996c; van Koningsbruggen e col, 2004). Os resultados dos estudos de expressão de FRG1 no músculo de pacientes com FSH são bastante controversos. Utilizando diferentes técnicas, como RT-PCR semi-quantitativo, RT-PCR quantitativo e "microarray", há evidências de que a expressão de FRG1 não está alterada, de que está 25 vezes aumentada ou até mesmo 5 vezes diminuída (Gabellini e col, 2002; Jiang e col, 2003; Winokur e col, 2003; van Deutekom e col 1996c). No entanto, camundongos transgênicos que superexpressam FRG1 no músculo esquelético desenvolvem distrofia muscular, com a gravidade do 
quadro-clínico proporcional ao nível de expressão (Gabellini e col, 2006). Além disso, foram observados no músculo esquelético destes camundongos, nas células $\mathrm{C} 2 \mathrm{C} 12$ que expressam $F R G 1$ e nos mioblastos de FSH, alterações no "splicing" de alguns mRNAs específicos de músculo (Gabellini e col, 2006).

\section{I.2.8.6. Alteração da expressão gênica in cis em FSH}

Tem sido atribuído também um papel indireto da contração de D4Z4 na patogênese de FSH. A alteração da estrutura da cromatina em D4Z4, devida, por exemplo, à hipometilação, poderia causar a perda do controle transcricional dos genes in cis. A identificação de um complexo repressor, composto por YY1, HMGB2 e nucleolina, que se liga a D4Z4 corrobora com o modelo da desregulação dos genes in cis. Nos controles normais, a presença do complexo repressor em mais de 10 repetições de D4Z4 poderia reprimir a expressão dos genes em 4q35, enquanto que nos pacientes de FSH, a deleção das repetições causaria a redução do complexo repressor ligado, resultando então no aumento da expressão dos genes in cis (Gabellini e cols, 2002).

Em um outro estudo foi identificado uma região associada à matriz nuclear (S/MAR) na região proximal de D4Z4 (Petrov e cols, 2006). As sequiências de S/MAR são importantes na organização do DNA em "loops" (Razin e cols, 2007). Em células de controles normais, S/MAR está localizado entre os genes candidatos $F R G 1$ e $F R G 2$ e as repetições de D4Z4, separando-os em dois "loops" distintos (Petrov e cols, 2006). Nos mioblastos de pacientes de FSH, há uma dissociação de S/MAR da matriz nuclear, deixando os genes in cis e as repetições de D4Z4 num mesmo "loop" (Petrov e cols, 2006). Como foi mostrado que a região 5' de D4Z4 apresenta um forte "enhancer", os genes $F R G 1$ e $F R G 2$ podem ter a expressão aumentada nos pacientes de FSH (Petrov e cols, 2008).

Embora foi mostrado que $F R G 1, F R G 2$ e ANT1 têm a expressão aumentada no músculo dos pacientes de FSH (Gabellini e col, 2002), vários outros estudos não puderam confirmar este resultado (Jiang e cols, 2003; Winokur e col, 2003; Osborne e col, 2007; Celegato e col, 2006). 


\section{I.2.8.7. Alteração da expressão gênica in trans em FSH}

Vários estudos têm mostrado que FSH pode ter um importante efeito in trans. $\mathrm{O}$ primeiro estudo a comparar o perfil de expressão gênica do músculo de pacientes com FSH mostrou um defeito na diferenciação miogênica (Winokur e col, 2003). Desde então, estudos de expressão gênica e de proteína têm sido realizados utilizando biópsias de músculo dos pacientes, indicando associações bem interessantes, como aumento do estresse oxidativo e uma possível ligação com a retinopatia (Osborne e col, 2007; Celegato e col, 2006).

Como já foi discutido anteriormente, um complexo repressor se liga a D4Z4 (Gabellini e col, 2002). A redução deste complexo no alelo com a contração pode não ter somente um efeito na regulação dos genes em 4q35, mas também ter um efeito mais global, resultando na interação do alelo contraído com diferentes proteínas (de Greef e col, 2008).

\section{I.2.8.8. A organização nuclear em FSH}

Os cromossomos ficam localizados em territórios dentro do núcleo. A localização de um gene dentro deste território determina a disponibilidade de proteínas regulatórias e o acesso do DNA ao aparato transcricional (Lanctoc e col, 2007).

O subtelômero $4 \mathrm{q}$ está preferencialmente localizado na periferia do núcleo, tanto em controles quanto nos pacientes com FSH. Outras regiões subteloméricas, incluindo 10qtel, estão localizadas mais para o interior do núcleo (Masny e col, 2004; Tam e col, 2004). Esta localização de 4qtel na periferia parece estar relacionada com alguma propriedade intrínseca do 4qtel, já que o cromossomo $\mathrm{X}$ localiza-se mais para a periferia nas células com a translocação $\mathrm{X} ; 4$, contendo $4 \mathrm{Mb}$ distal de 4 qtel. A região proximal de D4Z4 parece ser a responsável por esta localização perinuclear (Masny e col, 2004; Tam e col, 2004). A integridade da lamina parece ter um papel importante na localização de 4qtel, já que nos fibroblastos sem lamina A/C, a localização periférica de 4qtel não é observada (Masny e col, 2004; Tam e col, 2004). 
Embora não há diferença na localização de 4qtel nos controles e nos afetados, a interação entre 4qtel e o envelope nuclear pode estar prejudicada em FSH, devida a alteração na estrutura da cromatina em D4Z4 e a redução das proteínas do complexo repressor que podem interagir com a lamina nuclear. Interessantemente, outras doenças neuromusculares, como as distrofias musculares de Emery-Dreifuss (EDMD) ligada ao X e a forma autossômica dominante são causadas por mutações na emerina e na lamina $\mathrm{A} / \mathrm{C}$ (Worman \& Bonne, 2007). Além disso, seis proteínas de transmembrana do envelope nuclear foram identificadas e acredita-se que elas possam ter uma função importante na diferenciação de mioblastos e/ ou na manutenção do músculo (Chen e col, 2006). Por fim, estudos têm mostrado que FSH e EDMD estão relacionados (Bakay e col, 2006) e que o aumento da expressão de $D U X 4$ pode redistribuir a emerina no envelope nuclear (Kowaljow e col, 2007). Concluindo, uma das hipóteses é de que FSH pode surgir da alteração nas interações no envelope nuclear.

\section{I.3. Tratamentos}

A grande desvantagem da FSH em relação às outras formas de distrofia é o fato de que ainda não se identificou o gene responsável, o que dificulta o desenvolvimento de abordagens terapêuticas. Entretanto, algumas terapias já foram testadas.

A predinisona $1.5 \mathrm{mg} / \mathrm{kg} / \mathrm{dia}$ foi testada em 8 pacientes por causa dos infiltrados inflamatórios nas biópsias de músculo. No entanto, após 3 meses nenhuma diferença significativa na massa muscular e na força foi notada (Tawil e col, 1997).

Em seguida, o albuterol foi testado por causa dos seus efeitos conhecidos na musculatura e na medicina esportiva. Nos primeiros 3 meses foi observado um aumento da massa e da força muscular, mas nenhum aumento significativo ao final de um ano (Kissel e col, 2001). Um estudo semelhante com albuterol foi realizado na Holanda. Os resultados mostraram uma melhora significativa da força do músculo isométrico, mas não houve efeito positivo na dor e na fadiga (van der Kooi e col, 2004).

Uma outra tentativa foi realizada com suplementação de monohidrato de creatina, baseando-se na hipótese de que a quantidade de fosfocreatina estaria diminuída em alguns músculos distróficos e a creatina poderia proteger as células musculares. A 
suplementação com creatina, por 8 semanas, em pacientes com diversas formas de distrofias musculares, incluindo 12 pacientes com FSH, demonstrou uma leve melhora na força dos mesmos (Walter e cols., 2000). Entretanto, devido à curta duração e ao número reduzido de indivíduos, não foi possível concluir a respeito da utilidade da suplementação com creatina em FSH (Rose \& Tawil, 2004).

Em um outro estudo, diltiazem 30mg foi utilizado em 20 pacientes. A massa e a força muscular não mudaram significativamente após 6 meses (Elsheikh e col, 2006).

Como a deleção das repetições de D4Z4 está ligada à hipometilação, foi estudado também o efeito da suplementação com ácido fólico $(5 \mathrm{mg} /$ dia) e metionina $(1 \mathrm{gm})$ na metilação de D4Z4 após 12 meses. Nenhuma diferença significativa no nível de metilação em D4Z4 foi observada nos pacientes ou controles (van der Kooi, 2006).

\section{I.4. Objetivos}

Dada a grande variabilidade no quadro-clínico dos pacientes com FSH, tanto inter- como intrafamiliarmente e a nossa observação de que os portadores assintomáticos estão concentrados em determinadas famílias, este projeto tem como objetivo principal tentar entender os mecanismos que possam estar envolvidos na "proteção" contra a doença nestes indivíduos. Para isto, serão comparados o perfil de expressão gênica a partir das biópsias de músculo de pacientes afetados, portadores assintomáticos e controles normais de 5 famílias através da técnica de microarray. Como conseqüência, esperamos obter novos conhecimentos a respeito do mecanismo molecular de FSH. 


\section{CAPÍTULO II}

\section{II-METODOLOGIAS COMPLEMENTARES}

\section{II.1. Extração de DNA líquido a partir de sangue periférico}

A extração de DNA genômico dos pacientes e seus familiares foi realizada a partir de $10 \mathrm{~mL}$ de sangue periférico coletados em tubos contendo EDTA 5\%. A metodologia utilizada foi a descrita por Miller e cols. (1988) com algumas modificações, conforme se segue:

1. Transferir o sangue para um tubo de polipropileno, completar para $50 \mathrm{~mL}$ com uma solução de lise e homogeneizar, invertendo o tubo várias vezes;

2. Manter o tubo no gelo por 30 minutos para a obtenção da lise das hemácias;

3. Centrifugar por 15 minutos a 1.800 rotações por minuto (rpm);

4. Desprezar o sobrenadante e ressuspender o precipitado em $10 \mathrm{~mL}$ de solução de lise;

5. Centrifugar por 5 minutos a $1.800 \mathrm{rpm}$;

6. Desprezar o sobrenadante e ressuspender o precipitado em $3 \mathrm{~mL}$ de solução de lise de membrana nuclear;

7. Adicionar $50 \mu \mathrm{L}$ de pronase $\mathrm{E}$ ou $70 \mu \mathrm{L}$ de proteinase $\mathrm{K}$ na concentração de $10 \mathrm{mg} / \mathrm{mL}$ e $300 \mu \mathrm{L}$ de SDS $10 \%$

8. Homogeneizar levemente e incubar os tubos a $37^{\circ} \mathrm{C}$ por um período de 24 horas;

9. Após a incubação, adicionar $1 \mathrm{~mL}$ de $\mathrm{NaCl} 6 \mathrm{M}$ e misturar;

10. Centrifugar por 20 minutos a $2.500 \mathrm{rpm}$;

11. Transferir o sobrenadante para um tubo limpo e centrifugar novamente por 15 minutos a $2.500 \mathrm{rpm}$;

12. Transferir o sobrenadante para um tubo de vidro. Precipitar o DNA adicionando-se duas vezes o volume de etanol absoluto e invertendo algumas vezes com cuidado;

13. Coletar o DNA com o auxílio de um capilar de vidro com a extremidade soldada; 
14. Lavar o DNA em etanol $70 \%$ e colocá-lo em um tubo de microcentrífuga devidamente identificado;

15. Dissolver o DNA no tubo acrescentando-se $400 \mu \mathrm{L}$ de solução de $\mathrm{TE}^{-4}$ e desprezar o capilar de vidro;

16. Incubar a $65^{\circ} \mathrm{C}$ por 30 minutos para eliminar a contaminação por DNAse e armazenar as amostras a $4^{\circ} \mathrm{C}$.

\section{II.2. Análises utilizadas no diagnóstico de FSH}

- Digestão do DNA para eletroforese linear:

Este é o método mais utilizado no diagnóstico de FSH. Permite determinar o tamanho de alelos entre $50 \mathrm{~kb}$ e $9 \mathrm{~kb}$. São utilizados $5 \mu \mathrm{g}$ de DNA genômico em um volume total de $30 \mu \mathrm{L}$ de digestão. Cada amostra é digerida separadamente com a enzima de restrição $E c o$ RI e $E c o$ RI $/ B \ln \mathrm{I}$, sendo utilizados 15 unidades de enzima, $3 \mu \mathrm{L}$ de tampão 10 vezes concentrado, $10 \mathrm{mM}$ de espermidina e água destilada para completar o volume de $30 \mu \mathrm{L}$. O tempo de digestão é de no mínimo cinco horas na estufa a $37^{\circ} \mathrm{C}$.

Os fragmentos são separados por eletroforese em gel de agarose 0,5\% com tampão TAE $1 \mathrm{X}$ a 25 volts durante 72 horas, corado com brometo de etídeo. Após a transferência a membrana é hibridizada com a sonda p13E-11.

- Digestão do DNA para eletroforese em campo pulsado (PFGE):

O PFGE é usado para a distinção entre os fragmentos provenientes do cromossomo 4 e do 10 maiores que $50 \mathrm{~kb}$.

Para DNA líquido a digestão é realizada com $5 \mu \mathrm{g}$ de DNA, para volume final de $30 \mu \mathrm{L}$, adicionando-se $3 \mu \mathrm{L}$ de tampão $10 \mathrm{x}$ concentrado, $10 \mathrm{mM}$ espermidina e 15 unidades das enzimas EcoRI e Hind III ou EcoRI e BlnI. As condições são as mesmas para a digestão apenas com HindIII.

O gel de agarose tem concentração de $0,9 \%$ com tampão TBE $0,5 x$. A corrida é realizada durante 22 horas, a $20^{\circ} \mathrm{C}, 6 \mathrm{~V} / \mathrm{cm}$ e com pulsos que variam de 1 a 16 segundos. 
O gel é corado com brometo de etídeo e após a transferência, as membranas com as digestões de EcoRI/HindIII e EcoRI/BlnI podem ser hibridizadas com as sondas p13E-11 e 9B6A. Já as membranas com amostras digeridas somente com HindIII são hibridizadas primeiro com a sonda 4qA e após a remoção desta, com a sonda 4qB.

\section{II.3. "Southern blotting"}

Após a eletroforese é realizado o "Southern Blot", que consiste na transferência do DNA digerido, do gel para uma membrana de nylon por capilaridade. Para isto, o gel é lavado duas vezes com uma solução de desnaturação $(0,4 \mathrm{M}$ de $\mathrm{NaOH}$ e $0,6 \mathrm{M}$ de $\mathrm{NaCl})$ durante 20 minutos cada lavagem. Em um recipiente contendo a solução de transferência (desnaturação), são colocadas folhas de papel de filtro saturadas com a solução de transferência sobre uma plataforma, e em seguida, o gel, a membrana de nylon (HybondN+ - GE Healthcare) e sobre esta uma pilha de folhas de papel toalha. No dia seguinte, a membrana de nylon é lavada durante 7 minutos com uma solução de neutralização (2x SSC; $0,2 \mathrm{M}$ Tris- $\mathrm{HCl} \mathrm{pH} 7,5)$ e colocada na estufa a $80^{\circ} \mathrm{C}$ por duas horas para fixar o DNA.

Para hibridizar a membrana, esta é colocada em um saco plástico e adiciona-se $10 \mathrm{~mL}$ da solução de pré-hibridização junto com $120 \mu \mathrm{L}$ de DNA de esperma de salmão já desnaturado. Incuba-se a membrana na estufa a $42^{\circ} \mathrm{C}$ por pelo menos $1 \mathrm{~h}$.

A sonda p13E-11 é então marcada com radioativo $\left[\alpha-{ }^{32} \mathrm{P}\right] \mathrm{dCTP}$, de acordo com o protocolo do kit "Random Primers DNA Labeling System" (Invitrogen, Carlsbad, CA, USA):

Aproximadamente 70 - $100 \mathrm{ng}$ da sonda p13E-11 é dissolvida em água para volume final de $10 \mu \mathrm{L}$; desnatura-se a mistura durante 5 minutos a $100^{\circ} \mathrm{C}$; e imediatamente coloca-se no gelo.

Adiciona-se $2 \mu \mathrm{L}$ de cada solução de dATP, dGTP, dTTP; $15 \mu \mathrm{L}$ de "Random Primers Buffer Mixture"; $1 \mu \mathrm{L}$ de fragmento Klenow (3 U/ $\mu \mathrm{L})$ e $40 \mu \mathrm{Ci}$ de $\left[\alpha_{-}{ }^{32} \mathrm{P}\right] \mathrm{dCTP}$. 
Incuba-se a mistura por $1 \mathrm{~h}$ a $25^{\circ} \mathrm{C}$. Adiciona-se $5 \mu \mathrm{L}$ do Stop Mix e $2 \mu \mathrm{L}$ do DNA controle já marcado com radioativo. A mistura é fervida por 5 minutos e adiciona-se $5 \mathrm{~mL}$ de solução de hibridização.

Retira-se a solução de pré-hibridização da membrana e coloca-se a solução de hibridização com a sonda marcada, deixando na estufa a $42^{\circ} \mathrm{C}$ durante 1 "overnight".

No dia seguinte, a membrana é passada para um recipiente contendo $250 \mathrm{~mL}$ de solução de lavagem (2x SSC; 0,1x SDS) e deixada por aproximadamente 10 minutos no banho a $65^{\circ} \mathrm{C}$. A solução é jogada fora e é realizada mais uma lavagem.

Deixa-se a membrana em um cassete junto com o "storage phosphor screen" (GE Healthcare) por aproximadamente 2 dias. O "screen" é então escaneado no Storm (GE Healthcare)e o gel é analisado utilizando o software ImageQuant TL (GE Healthcare). 


\title{
CAPÍTULO III
}

\section{Transcriptional regulation differs in affected FSHD patients compared to asymptomatic related carriers}

\author{
Patricia Arashiro*, Iris Eisenberg ${ }^{\dagger}$, Alvin T. Kho ${ }^{\ddagger}$ Antonia M.P. Cerqueira*, Martha \\ Canovas*, Helga C.A. Silva ${ }^{\S}$, Rita C.M. Pavanello*, Louis M. Kunkel ${ }^{\dagger}$, Mayana Zatz* ${ }^{*}$ \\ *Human Genome Research Center, Department of Genetics and Evolutive Biology, \\ Institute of Biosciences, University of São Paulo, São Paulo, 05508-090, Brazil; ${ }^{\dagger}$ Howard \\ Hughes Medical Institute, Program in Genomics, Division of Genetics, ${ }^{+}$Informatics \\ Program, Children's Hospital, Harvard Medical School, Boston, MA 02115; ${ }^{\S}$ CEDHIMA \\ (Brazilian Center of Study, Diagnosis, and Investigation of Malignant Hyperthermia), \\ Dept. Surgery, Discipline of Anaesthesia, Pain and Intensive Care, University Federal of \\ São Paulo, São Paulo, 04024-002, Brazil
}




\begin{abstract}
Facioscapulohumeral Muscular Dystrophy (FSHD) is a progressive muscle disorder that has been associated with a contraction of $3.3 \mathrm{~kb}$ repeats on chromosome 4q35. FSHD is characterized by a wide clinical inter- and intrafamilial variability, ranging from wheelchair-bound patients to asymptomatic carriers. We compared the gene expression profiles from related affected, asymptomatic and control individuals from 5 families. Our results suggest that the expression of genes on chromosome $4 \mathrm{q}$ is altered in affected and asymptomatic individuals. Remarkably, the changes seen in asymptomatic samples are largely in products of genes encoding several chemokines, whereas the changes seen in affected samples are largely in genes governing the synthesis of GPIlinked proteins and histone acetylation. Besides this, the affected patient and related asymptomatic carrier share the 4qA161 haplotype. Thus these polymorphisms by themselves do not explain the pathogenicity of the contracted allele. Together, our results support the previous evidence that FSHD may be caused by transcriptional dysregulation of multiple genes, in cis and in trans, and suggest some factors potentially important for FSHD pathogenesis.
\end{abstract}




\section{Resumo}

A distrofia muscular fácio-escápulo-umeral (FSH) é uma doença muscular progressiva que tem sido associada com a contração de repetições de $3.3 \mathrm{~kb}$ do cromossomo 4q35. FSH é caracterizada por uma grande variabilidade clínica inter- e intrafamilial, que pode variar de pacientes em cadeira de rodas até os portadores assintomáticos. Comparando o perfil de expressão gênica de indivíduos afetados, assintomáticos e controles normais de 5 famílias diferentes, nossos resultados sugerem que a expressão dos genes no cromossomo $4 \mathrm{q}$ está alterada nos pacientes afetados e portadores assintomáticos. As diferenças encontradas nos portadores assintomáticos estão relacionadas com as quemocinas, enquanto que as diferenças observadas nos afetados estão relacionadas a genes dos processos ligados à acetilação de histonas e à modificação pós-traducional âncora-GPI (glicosilfosfatidilinositol). Além disso, observamos que os pacientes afetados e os portadores assintomáticos compartilham o haplótipo 4qA161 e, desta forma, estes polimorfismos sozinhos não explicam a patogenicidade do alelo com a contração. Nossos resultados corroboram com as evidências de que FSH deve ser causada pela alteração da regulação de múltiplos genes, tanto in cis como in trans, e sugerem alguns fatores que potencialmente devem ser importantes na patogênese de FSH. 


\section{Introduction}

Facioscapulohumeral Muscular Dystrophy (FSHD) is an autosomal dominant disorder, the locus of which has been mapped to the subtelomeric portion of chromosome 4 , at $4 \mathrm{q} 35$ (1). This region is characterized by a series of $3.3 \mathrm{~kb}$ repeats termed D4Z4. The D4Z4 array may vary from 11 to more than 100 units in the general population, whereas most FSHD patients have a partial deletion of an integral number of these repeats, and exhibit 10 or less units (2). Similarly sized D4Z4 regions are observed in affected relative members within families.

FSHD is typically characterized initially by facial muscle weakness. During progression, weakness and atrophy of shoulder girdle muscles is observed in almost all cases. A gradual spread to abdominal and foot-extensor muscles, followed by clinical involvement of upper arm and pelvic girdle muscles, is seen in most patients. Asymmetry of muscle involvement is common. Among the extramuscular features that may be associated with FSHD are retinal abnormalities and high-tone hearing loss (3). Depression, muscle pain and fatigue are also often observed among FSHD patients (4-6).

Although it is not possible to predict the course of the disease, there tends to be an inverse relationship between the residual repeat size, the age at onset, and the severity of the disease. Patients with 1-3 repeat units are usually very severely affected, whereas patients with 4-10 repeats tend to have a milder course (7).

FSHD is also characterized by interfamilial and intrafamilial variability, with severity ranging from asymptomatic carriers to loss of ambulation (8). Some families also show clinical anticipation, although all affected members carry the same deleted fragment $(9,10)$. Males are on average more often and more severely affected than females, with approximately $20 \%$ of individuals related to FSHD patients remaining asymptomatic (11, 12). Furthermore, these non-penetrant cases seem to be more common in particular families (13).

Several observations have suggested that FSHD is caused by a complex and uncommon mechanism. Despite the $98 \%$ of homology between the D4Z4 repeats at 4q35 and 10q26, and the equal frequency of translocations observed between these two regions, FSHD is uniquely associated with contractions on chromosome 4. Contraction of 
a translocated 4-type allele on chromosome 10 does not cause FSHD (14-16). As monosomy of 4qter is not associated with FSHD, it is believed that the presence of a small number of D4Z4 repeats is crucial to the process leading to the disease (17). It is not sufficient, however: studies of four different polymorphic markers showed that FSHD is restricted to one specific haplotype at 4q35ter, 4qA161 (18). In addition, the proximal unit of D4Z4 is significantly hypomethylated in affected and asymptomatic carriers, while in type 2 FSHD, a form of the disease that is not linked to contractions of D4Z4 repeats at 4q35, both alleles are significantly hypomethylated (19).

Some studies have proposed that FSHD is caused by the transcription of a putative gene encoded by the D4Z4 repeats, termed double homeobox 4 (DUX4) $(20,21)$. The overexpression of DUX4 is generally toxic to cells, leading to apoptosis and activation of PITX1 (paired-like homeodomain transcription factor 1). Changes in DUX4 or PITX1, both homeodomain proteins, could explain several of the key features in FSHD, including the left-right asymmetry, atypical inflammatory responses and defects in myoblasts reported in FSHD patients $(20,21)$. Another model suggests that overexpression of critical genes upstream of the D4Z4 repeats at 4q35 in FSHD patients causes a loss of position effect variegation (PEV) $(22,23)$. The findings that a repressor complex composed of YY1, HMGB2 and nucleolin bind to D4Z4 and that a nuclear matrix attachment site (S/MAR), located immediately upstream of D4Z4, dissociates from the nuclear matrix in FSHD patients, are consistent with a model for dysregulation of genes in $c i s$ as a primary event in FSHD $(24,25)$. Data consistent with such dysregulation have not been supported by several studies using gene array or quantitative reverse transcriptase polymerase chain reaction, however.

Despite the substantial effort to elucidate the molecular mechanism underlying FSHD, the exact mechanism is still unclear. It is also significant that neither of the proposed mechanisms can explain the clinical variability characteristic of FSHD, clinical anticipation, or why some individuals with 10 or fewer D4Z4 repeats remain asymptomatic. We postulated that these asymptomatic individuals might provide important clues about the pathogenesis of FSHD and the molecular mechanisms to suppress it. To test this, we compared the gene expression profiles from affected individuals, asymptomatic carriers and normal controls through microarray analysis, 
looking for genes that might be implicated in suppression or enhancement of the disease expressivity. We focused our studies on samples from related individuals, to minimize variations due to genetic background. The contribution of microRNAs to FSHD was also evaluated.

\section{Results}

\section{Expression profiles in affected patients and asymptomatic carriers}

The gene expression profiles from 3 related members (affected, asymptomatic carrier and control) from 5 different families were compared through microarrays. Using the criteria described in Materials and Methods for microarray data analysis to identify the differentially expressed genes among affected individuals, asymptomatic carriers and normal controls, we found 180 loci-annotated probes were found to be significantly dysregulated. When we compared the expression levels between the affected and asymptomatic, 147 probes were significantly dysregulated, of which 13 were upregulated in affected patients compared to asymptomatic relatives (SI Table 4 and SI Table 5). In comparisons of affected individuals and healthy controls, only 56 probes were differentially expressed, of which 20 were upregulated in affected relative to controls (SI Table 6 and SI Table 7). Comparisons of asymptomatic carriers and healthy controls identified 12 probes with a significant fold change, all of which were upregulated. Surprisingly, 5 of these probes represent genes from chromosome 4q (Table 1). The only gene similarly and significantly dysregulated in affected and asymptomatic carriers relative to control is IGHAl (Table 1), encoding an immunoglobulin heavy chain, suggesting that its upregulation might be related to the presence of the FSHD repeat contraction in these individuals.

The categories of biological processes that our results identified as altered in FSHD were categorized in the DAVID program. The biological processes most affected in FSHD patients, compared to controls, are involved in histone acetyltransferase and synthesis of glycosylphosphatidylinositol (GPI)-anchors (Table 2). In asymptomatic carriers, however, there is a clear prevalence of processes related to chemokines (Table 
2), and in affected versus asymptomatic samples, most of the categories are related to regulation of transcription (Table 2).

\section{Expression of $4 q 35$ genes}

To check if the genes previously reported to be dysregulated from the region in cis to $4 \mathrm{q} 35$ are specifically dysregulated in our affected patients population, we compared their expression among our 3 groups of samples. There was no hybridization signal for 2 genes - DUX4 and FRG2 (SI Table 8). There was no significant alterations in transcriptional level among affected, asymptomatic and controls for FRG1, PDLIM3 and ANT1 (SI Table 8). However, as reported elsewhere (21), the probes on U133 Plus 2.0 chip for DUX4 and FRG1 genes do not target the chromosome 4q35 genes specifically. The only significant differences in this set of genes were for ANKRD37 and F11 (SI Table 8), which were significantly dysregulated only in affected patients, compared to asymptomatic carriers. Their products could be involved in the pathogenesis of FSHD.

\section{Validation of microarray results}

The most interesting dysregulated genes were in asymptomatic muscle biopsies relative to control (Table 1) and were from chromosome 4q. It was necessary to validate their expression using all possible samples in order to determine if these genes would be candidates to suppress the FSHD phenotype in asymptomatic carriers. (Please note that RNA samples were not available from all the original samples used in generating the microarrays for this purpose). The four dysregulated genes from chromosome $4 \mathrm{q}$ (CXCL9, CXCL11, LOC91431 and STATH) were selected along with two other genes the expression of which appeared more homogeneous among the samples (PRIC285 and $L P P$ ), and also CXCL10, which is clustered between CXCL9 and CXCL11 on 4q21, for validation by quantitative RT-PCR. Comparisons of the expression levels of these genes in paired samples from the same family that showed CXCL9, CXCL10, CXCL11, STATH and LOC91431 are significantly upregulated in asymptomatic carriers compared to affected individuals (Table 3). However, when other samples from unrelated affected and asymptomatic individuals with different numbers of residual D4Z4 are included, there is no difference in the relative expression of those genes by RT-PCR in affected and 
asymptomatic groups (SI Table 9). Interestingly, a graph of these results, considering the fold changes for affected and asymptomatic as a function of the residual number of D4Z4 repeats (Figure 1), revealed a correlation between the expression levels of the chemokines and the residual number of D4Z4 in affected patients, but not in asymptomatic carriers. In contrast, negative correlations were found for LOC91431 in asymptomatic carriers (Figure 2). Given the small sample size available for the validation through RT-PCR, some of the calculated correlations are not significant ( $p>0.05)$.

\section{Characterization of polymorphisms from $4 q 35$}

As it was previously reported that only contraction of D4Z4 repeats in 4qA161 haplotype was found to cause FSHD, while contractions in other common 4q haplotypes are nonpathogenic (18), we tested if the affected and related asymptomatic individuals, sharing the same FSHD contraction, have different haplotypes that could be associated with the expression of the disease. We examined several polymorphisms on 4qter: the subtelomeric variations distal to D4Z4 - A and B - which can be distinguished by the presence of a beta satellite DNA on A-type alleles, the G/C SNP within the most proximal D4Z4 unit, and a simple sequence-length polymorphism (SSLP) located $3.5 \mathrm{~kb}$ proximal to D4Z4. The polymorphisms, when compared in affected and related asymptomatic carrier, can determine their correlation with the pathogenicity of the contracted allele. All tested individuals (from families 1-5, SI Table 10) shared the 4qA allele and the same SNP in D4Z4 (G). In addition, the 4qA161 haplotype was carried in all families tested, with the exception of family 4 , in which the affected individual has the 4qA161/4qA166 haplotypes, while the asymptomatic carrier has the 4qA159/ 4qA166 haplotypes (data not shown).

\section{microRNAs in FSHD}

MicroRNAs (miRNAs) are a class of small non-coding RNAs that are increasingly recognized for their ability to regulate gene expression posttranscriptionally. Among other targets, miRNAs in skeletal muscle regulate the expression of transcription factors and signaling mediators important for muscle biology, which in turn can influence proliferation and differentiation during myogenesis $(27,28)$. 
The expression profiles of miRNAs in 10 different groups of muscle disorders, including FSHD, were recently compared (29) and 62 miRNAs that were differentially expressed in FSHD muscle - all upregulated - were identified. The predicted targets for these differentially expressed miRNAs were compared to the gene products identified here as downregulated in FSHD patients, compared to healthy controls. MAMI (MetA Mir:target Inference) was used to predict the targets for the dysregulated miRNAs. Several different miRNAs target the same gene (SI Table 11), such as ATG16L1, EPAS1 and $P C D H 9$, which are downregulated in biopsy samples from affected patients. These same genes, ATG16L1, EPAS1 and PCDH9, are also downregulated in affected individuals relative to asymptomatic carriers (SI Table 5), which suggests that their downregulation by miRNAs may be linked to the pathophysiology of FSHD. Perhaps significantly, most of these predicted targets take part in histone acetylation and the synthesis of GPI-anchors, both of which are dysregulated in affected patients vs healthy controls (Table 2).

\section{Discussion}

Although FSHD was among the first of the muscular dystrophies to have its locus mapped, the molecular mechanism leading to the disease is still unclear. The unspecific histological alterations in muscle and the high clinical variability observed among patients do not give any clues about a possible mechanism underlying FSHD. One possible way to understand the pathology would be to examine the differences in the expression of genes in patients with FSHD and in their close relations who are asymptomatic carriers. The present study is the first to make such a comparison, which minimizes the effects deriving from differences in genetic background, and likely gives more consistent and reliable results with microarray analysis $(30,31)$. In addition, all muscle biopsies were collected by the same physician and were processed in the same way, keeping variations from technical sources to a minimum. The results support the evidence that the expression of some genes in FSHD, and particular those at chromosome $4 \mathrm{q}$, is abnormal in FSHD patients. 
The finding that the genes from the chemokine cluster on $4 \mathrm{q} 21$, that are located more than $100 \mathrm{Mbp}$ from $\mathrm{D} 4 \mathrm{Z} 4$ repeats, have a similar expression pattern (CXCL9 $>C X C L 1 O>C X C L 11)$ in all tested affected patients through RT-PCR suggests that these three chemokines may be under control of the same regulator(s) in FSHD patients, in contrast to asymptomatic carriers. The IFN- $\gamma$ induced chemokines CXCL9, CXCL10 and CXCL11 are ligands for CXCR3 receptor, and are thought to play a key role in directing activated $\mathrm{T}$ cells and other cell types (such as NK cells and macrophages) to sites of inflammation. The upregulation of these chemokines have not been described in either FSHD or other forms of muscular dystrophy (26, 32-35), suggesting that their expression is unlikely to be linked to inflammatory cell infiltrates. The fact that there was no difference in the expression levels of these chemokines as well as the other genes validated - STATH, LOC91431, LPP and PRIC285 - between affected patients and asymptomatic carriers when additional samples were included, lessens the likelihood that these genes could be suppressing the FSHD phenotype in asymptomatic carriers. On the other hand, our microarray and RT-PCR data suggest that the contraction of repeats in affected patients and asymptomatic carriers might disturb the gene expression in cis. This observation is supported by the finding that the contracted allele is significantly hypomethylated in both affected individuals and asymptomatic carriers (19). These studies did not look at the differential expression of FRG1 or DUX4 in FSHD patients biopsies. There was evidence that the microarray data that indicated from chromosome 4q35, ANKRD37 and F11 genes are differentially expressed when compared between affected patients and asymptomatic individuals, suggesting that these 2 groups may have some specific differences on $4 q 35$. In the 4 families tested, it appeared that the affected patients and related asymptomatic carriers share the same 4qA161 haplotype. Thus, these polymorphisms by themselves cannot explain the pathogenicity linked to the contraction of D4Z4 repeats, and other factor(s), perhaps acting in cis, are likely to be important in the disease mechanism. Further studies concerning the differences between affected patients and asymptomatic carriers are of utmost importance, and will certainly help in our knowledge about factors necessary to trigger FSHD.

The data presented here indicated that the biological process that may be specifically impaired in FSHD patients involves the synthesis of GPI-anchors. The 
structure of the GPI anchor is composed of short chains of sugars, specifically mannose and glucosamine, which are assembled in the endoplasmic reticulum and linked to the inositide residues of phosphatidylinositol. After synthesis, the entire glycolipid is transferred to C-terminal regions of proteins posttranslationally, thereby anchoring these proteins to the outer leaflet of the cell membrane, where they tend to associate with lipid rafts (36). GPI anchors also have roles in membrane diffusion, intracellular protein sorting and signaling (37). A major subclass of rafts is caveolae, which are invaginations of the cell membrane characterized by the abundance of caveolin. Caveolae contain clusters of GPI-anchored proteins, the most well studied of which is the folate receptor. However, evidence also exists for the presence of other GPI-anchored proteins, such as alkaline phosphatase, Thy-1, and prion $\operatorname{PrP}(\mathrm{C})$ in caveolae (38). No caveolae abnormalities in muscle plasma membranes from FSHD patients were found in one study (39). However, alterations in the sarcolemmal reorganization in muscle tissue from FSHD patients have been reported (40). The steps in GPI assembly, and the enzymes that carry them out, are highly conserved. The genes found to be downregulated in biopsies from FSHD patients presented here and that take part in this biological process are involved in the catalytic steps of the GPI biosynthetic pathway. The importance of GPI anchoring in mammals is underscored by the fact that abrogation of GPI biosynthesis results in embryonic lethality (41). Defects in $O$-glycan biosynthesis are associated with congenital muscular dystrophies, further studies concerning alterations in the GPI-anchor and other glycan structures from caveolae and other proteins associated with the sarcolemma in FSHD should be pursued.

The changes in gene expression observed here may also be linked to changes in histone acetylation, which occur only in affected patients and not in asymptomatic carriers. Histone modifications may directly affect chromatin structure by preventing the binding of transcription factors, altering the interactions between nucleosomes or changing the interactions of the histone tails with DNA in the nucleosome (42). Although previous studies $(43,44)$ on histone $\mathrm{H} 4$ acetylation levels in the proximal region of D4Z4 did not find any difference between affected individuals and healthy controls, the specific state of the chromatin at the D4Z4 repeats of chromosome $4 \mathrm{q} 35$ has not yet been studied 
in affected patients, due to the lack of specific primers but such studies could yield interesting findings.

Our study suggests that changes in the expression of miRNAs may also be pathogenic in FSHD. Our results are consistent with another study that profiled the expression of miRNAs in FSHD, and suggest that the downregulation of mRNA levels encoding ATG16L1, EPAS1 and PCDH9 in affected individuals, but not in asymptomatic carriers or healthy controls, may be mediated at least in part by increases in the levels of miRNA that target these gene products.

In summary, there appears to be a profound difference in the transcriptional regulation between affected patients and asymptomatic carriers. The contraction of D4Z4 repeats seems to affect the transcription of genes at $4 \mathrm{q}$, in both groups, but they suggest that factors in other regions of the genome are also associated with the pathogenesis of FSHD. Nevertheless, perturbations in histone acetylation may affect the chromatin structure specifically in the affected patients, leading to the pathogenic changes associated with the disease. Similarly, differences in the synthesis of GPI-anchored proteins may also be linked to muscle pathology in affected individuals. In addition, our results indicate that the miRNAs play a role in the regulatory network in FSHD, increasing the complexity of the mechanism underlying the disease. The study of expression profiles from asymptomatic carriers is a novel approach that has revealed these new and interesting findings, and in the future should contribute to a better understanding of FSHD.

\section{Materials and Methods}

\section{Muscle Biopsies}

Muscle biopsies were taken from related members (affected, asymptomatic carrier and normal control) belonging to six unrelated families (see families 1-6 on SI Table 10). In family 6, muscle biopsies from 2 affected patients were taken. Asymptomatic carriers

were considered those older than 30 years old, without any FSHD clinical signal, but who share the deleted fragment in common with their clinically affected relative. Additional 
biopsies were also collected from single members of additional families (families 7-11 on SI Table 10). The asymptomatic carriers corresponding to \#20, 21, 23 and 24 samples also have at least one related affected who shares the same FSHD allele. The presence of mosaicism had been previously excluded through pulsed field gel electrophoresis. Muscle biopsies were taken from the biceps in four families and from the deltoid in the remaining two, because the clinically affected patients had a severe atrophy. The same muscle was taken from all individuals within each family in order to minimize variability. One portion of each biopsy was frozen for molecular studies and another for histological analysis (SI Figure 4). All the biopsies were taken at the Human Genome Research Center (University of São Paulo, Brazil) after informed consent.

\section{RNA isolation}

The frozen muscle tissue was ground in dry ice in a mortar, and the total RNA was isolated from muscle tissue using the TRIReagent method (Molecular Research Center, Inc.) following the manufacturer's protocol. For details, see SI Text.

\section{Microarray assay}

$1 \mu \mathrm{g}$ of total RNA was copied by reverse transcriptase using a T7-Oligo(dT) Promoter Primer and SuperScript II in the first-strand cDNA synthesis reaction. Following RNase H-mediated second-strand cDNA synthesis, the double-stranded cDNA was purified using "Sample Cleanup Module" kit (Affymetrix). The cDNA served as a template in the subsequent in vitro transcription (IVT) reaction. The IVT was carried out at $37{ }^{\circ} \mathrm{C}$ for 16 hours in the presence of T7 RNA Polymerase and a biotinylated nucleotide analog/ ribonucleotide mix for complementary RNA (cRNA) amplification and biotin labeling. The biotinylated cRNA was purified with "Sample Cleanup Module" kit (Affymetrix) and quantified (NanoDrop company). 20 $\square \mathrm{g}$ of cRNA was fragmented randomly to 35 to 200 bases at $94{ }^{\circ} \mathrm{C}$ for 35 minutes. $15 \square \mathrm{g}$ of fragmented cRNA was hybridized to U133 Plus 2.0 chips for 16 hours at $45^{\circ} \mathrm{C}, 60 \mathrm{rpm}$. The chips were washed and stained by the Affymetrix Fluidics Station 450, using instructions and reagents provided by Affymetrix. This step involves removal of non-hybridized probes and incubation with Streptavidin Phycoerythrin (SAPE) to detect bound probes. 


\section{Microarray Data Analysis}

A probe-by-probe differential fold analysis was performed between any 2 sample populations - control vs asymptomatic, control vs. affected, asymptomatic vs. affected using a geometric logarithmic fold method. For details see SI Text.

\section{Gene Ontology Enrichment Analysis}

We performed a gene ontology (GO) enrichment analysis of the list of probes of interest using DAVID 2008 (http://david.abcc.ncifcrf.gov) data freeze June 2008. These lists were restricted to probes that had an Entrez gene assignment and duplicated/redundant Entrez genes were removed. The background gene set was 19,501 unique Entrez genes assayed on the Affymetrix Human Genome GeneChip® Human Genome U133 Plus 2.0 microarray. We identified ontologic categories that had a Fisher exact p-value (EASE score) <0.05 (45). This analysis was performed on the significantly dysregulated genes.

\section{$R T-P C R$ validation of microarray data}

Starting with 500ng of total RNA, cDNA syntheses were accomplished as above with Random Primers (Invitrogen, Carlsbad, CA, USA), and SuperScript II (Invitrogen) in $20 \mu \mathrm{L}$ reactions. TaqMan Gene Expression Assays (Applied Biosystems, Foster City, CA) for each sample were performed in duplicate in 96-well optical plates on cDNA equivalent to $100 \mathrm{ng}$ of total RNA. The $20 \mu \mathrm{L}$ reactions contained $5.0 \mu \mathrm{L}$ nuclease-free water, 10.0 $\mathrm{LL} 2 \mathrm{x}$ TaqMan Universal PCR Master Mix (Applied Biosystems), 1.0 $\square \mathrm{L} \mathrm{20x}$ TaqMan Gene Expression Assay Mix (consisting of unlabeled PCR primers and FAM dye-labeled MGB probe; Applied Biosystems), and 4.0 $\mu \mathrm{L}$ cDNA. For each gene, one notarget control, with no cDNA, was also performed. Thermal cycling conditions were 2 minutes at $50^{\circ} \mathrm{C}$ and 10 minutes at $95^{\circ} \mathrm{C}$, followed by 40 cycles at $95^{\circ} \mathrm{C}$ for 15 seconds and $60^{\circ} \mathrm{C}$ for 1 minute. Data were collected using the ABI PRISM 7900HT Sequence Detection System (Applied Biosystems) and were analyzed through comparative $\mathrm{C}_{\mathrm{T}}$ method $(\Delta \Delta \mathrm{Ct})$. $\beta$-actin was used as an endogenous control as it was not observed as 
differentially expressed among the three groups (affected, asymptomatic and control) according to microarray data.

\section{Characterization of 4935 alleles}

After isolation of DNA from peripheral blood, the DNA was digested with HindIII and separated by electrophoresis on agarose gels, followed by transfer to Hybond membrane (GE Healthcare) by Southern blotting. The membrane was hybridized with probes that specifically distinguish these alleles, as described in (10). The D4Z4 SNP and the SSLP of all individuals studied in the present work were defined as in (18).

\section{Acknowledgements}

We thank all families, whose collaboration was essential for this study, and also Constância Urbani. The collaboration of the following persons is also gratefully acknowledged: Dr. Mariz Vainzof, Lydia Yamamoto and Dr. Ivo Pavanello for helping with the muscle biopsies; Richard J.L.F. Lemmers for helping with SSLP genotyping; all members from M.Z.'s lab, Genri Kawahara, Juan C. Casar, Hart Lidov and Anu Balasubramanian for helpful suggestions. This study was supported by FAPESP-CEPID, CNPq and FSH Society. L.M.K. is an Investigator with the Howard Hughes Medical Institute.

\section{References}

1. Wijmenga C et al. (1990) Location of facioscapulohumeral muscular dystrophy gene on chromosome 4. Lancet 336:651-653.

2. van Deutekom JCT et al. (1993) FSHD associated DNA rearrangements are due to deletions of integral copies of a $3.2 \mathrm{~kb}$ tandemly repeated unit. Hum Molec Genet 2: 2037-2042. 
3. Padberg GW et al. (1995) On the significance of retinal vascular disease and hearing loss in facioscapulohumeral muscular dystrophy. Muscle Nerve 2:S73-S80.

4. Bungener C, Jouvent R, Delaporte C. (1998) Psychopathological and emotional deficits in myotonic dystrophy. J Neurol Neurosurg Psychiatry 65: 353-356.

5. Kalkman JS, Schillings ML, Zwarts MJ, van Engelen BGM, Bleijenberg G (2007) Psychiatric disorders appear equally in patients with myotonic dystrophy, facioscapulohumeral dystrophy, and hereditary motor and sensory neuropathy type I. Acta Neurol Scand 115: 265-270.

6. Pandya S, King WM, Tawil R (2008) Facioscapulohumeral Dystrophy. Phys Ther 88: 105-113.

7. Lunt PW et al. (1995) Phenotypic-Genotypic correlation will assist genetic counseling in 4q35- facioscapulohumeral muscular dystrophy. Muscle Nerve 2: S103S109.

8. Padberg GW et al. (1995) Facioscapulohumeral muscular dystrophy in the dutch population. Muscle Nerve 2: S81-S84.

9. Zatz M et al. (1995) High Proportion of New Mutations and Possible Anticipation in Brazilian Facioscapulohumeral Muscular Dystrophy Families. Am J Hum Genet 56:99-105.

10. Tonini MMO et al. (2004) Homozygosity for autosomal dominant facioscapulohumeral muscular dystrophy (FSHD) does not result in a more severe phenotype. J Med Genet 41: e17-22.

11. Padberg GW, Lunt PW, Koch M, Fardeau M (1991) Diagnostic criteria for facioscapulohumeral muscular dystrophy. Neuromuscul Disord 1: 231-234.

12. Zatz M et al. (1998) The Facioscapulohumeral Muscular Dystrophy (FSHD1) Gene Affects Males More Severly and More Frequently Than Females. Am J Med Genet 77: $155-161$

13. Tonini MMO et al. (2004) Asymptomatic carriers and gender differences in facioscapulohumeral muscular dystrophy (FSHD). Neuromuscul Disord 14: 33-38.

14. Deidda G et al. (1995) Physical mapping evidence for a duplicated region on chromosome 10qter showing high homology with the facioscapulohumeral muscular dystrophy locus on chromosome 4qter. Eur J Hum Genet 3: 155-167. 
15. van Deutekom JCT et al. (1996) Evidence for subtelomeric exchange of $3.3 \mathrm{~kb}$ tandemly repeated units between chromosomes 4q35 and 10q26: implications for genetic counseling and etiology of FSHD1. Hum Mol Genet 5: 1997-2003.

16. Lemmers RJLF et al. (1998) Inter- and intrachromosomal sub-telomeric rearrangements on 4q35: implications for facioscapulohumeral muscular dystrophy (FSHD) aetiology and diagnosis. Hum Mol Genet 7: 1207-1214.

17. Tupler R et al. (1996) Monosomy of distal 4q does not cause facioscapulohumeral muscular dystrophy. J Med Genet 33: 366-370.

18. Lemmers RJLF et al. (2007) Specific Sequence Variations within the 4q35 Region are Associated with Facioscapulohumeral Muscular Dystrophy. Am J Hum Genet 81: 884-94.

19. van Overveld PGM et al. (2003) Hypomethylation of D4Z4 in 4q-linked and non-4qlinked facioscapulohumeral muscular dystrophy. Nat Genet 35: 315-7.

20. Kowaljow V et al. (2007) The DUX4 gene at the FSHD1A locus encodes a proapoptotic protein. Neuromuscul Disord 17: 611-623.

21. Dixit $\mathrm{M}$ et al. (2007) DUX4, a candidate gene of facioscapulohumeral muscular dystrophy, encodes a transcriptional activator of PITX1. Proc Natl Acad Sci USA 104: 18157-62.

22. Hewitt JE et al. (1994) Analysis of the tandem repeat locus D4Z4 associated with facioscapulohumeral muscular dystrophy. Hum Molec Genet 3: 1287-95.

23. Winokur ST et al. (1994) The DNA rearrangement associated with facioscapulohumeral muscular dystrophy involves a heterochromatin-associated repetitive element: implications for a role of chromatin structure in the pathogenesis of the disease. Chromosome Res 2: 225-34.

24. Gabellini D, Green MR, Tupler R (2002) Inappropriate Gene Activation in FSHD: A Repressor Complex Binds a Chromosomal Repeat Deleted in Dystrophic Muscle. Cell 110: 339-48.

25. Petrov A et al. (2006) Chromatin loop domain organization within the 4q35 locus in facioscapulohumeral dystrophy patients versus normal human myoblasts. Proc Natl Acad Sci USA 103: 6982-87. 
26. Osborne RJ, Welle S, Venance SL, Thornton CA, Tawil R (2007) Expression profile of FSHD supports a link between retinal vasculopathy and muscular dystrophy. Neurology 68: 569-77.

27. Chen JF et al. (2006) The role of microRNA-1 and microRNA-133 in skeletal muscle proliferation and differentiation. Nat Genet 38: 228-33.

28. Callis TE, Deng Z, Chen JF, Wang DZ (2008) Muscling Through the microRNA World. Exp Biol Med 233: 131-8.

29. Eisenberg I et al. (2007) Distinctive patterns of microRNA expression in primary muscular disorders. Proc Natl Acad Sci USA 104: 17016-21.

30. Cheung VG et al. (2003) Natural variation in human gene expression assessed in lymphoblastoid cells. Nat Genet 33: 422-25.

31. Sharma A et al. (2005) Assessing natural variations in gene expression in humans by comparing with monozygotic twins using microarrays. Physiol Genomics 21: 117-23.

32. Celegato B et al. (2006) Parallel protein and transcript profiles of FSHD patient muscles correlate to the D4Z4 arrangement and reveal a common impairment of slow to fast fibre differentiation and a general deregulation of MyoD-dependent genes. Proteomics 6: 5303-21.

33. Winokur ST et al. (2003) Expression profiling of FSHD muscle supports a defect in specific stages of myogenic differentiation. Hum Mol Genet 12: 2895-907.

34. Campanaro $\mathrm{S}$ et al. (2002) Gene expression profiling in dysferlinopathies using a dedicated muscle microarray. Hum Mol Genet 11: 3283-98.

35. Bakay M, Zhao P, Chen J, Hoffman EP (2002) A web-accessible complete transcriptome of normal human and DMD muscle. Neuromuscul Disord 12: S125-41.

36. Paulick MG, Bertozzi CR (2008) The glycosylphosphatidylinositol anchor: a complex membrane-anchoring structure for proteins. Biochemistry 47: 6991-7000.

37. Freeze HH (2006) Genetic defects in the human glycome. Nat Rev Genet 7: 537-51.

38. Anderson RG, Jacobson K (2002) A role for lipid shells in targeting proteins to caveolae, rafts, and other lipid domains. Science 296: 1821-5.

39. Bonilla E, Fischbeck K, Schotland DL (1981) Freeze-fracture studies of muscle caveolae in human muscular dystrophy. Am J Pathol 104: 167-73. 
40. Reed P et al. (2006) Sarcolemmal reorganization in facioscapulohumeral muscular dystrophy. Ann Neurol 59: 289-97.

41. Nozaki M et al. (1999) Developmental abnormalities of glycosylphosphatidylinositolanchor-deficient embryos revealed by Cre/loxP system. Lab Invest. 79: 193-9.

42. Peterson CL, Laniel MA (2004) Histones and histone modifications. Curr Biol 14: R546-R551.

43. Jiang $G$ et al. (2003) Testing the position-effect variegation hypothesis for facioscapulohumeral muscular dystrophy by analysis of histone modification and gene expression in subtelomeric 4q. Hum Molec Genet 12: 2909-2921.

44. Yang F, Shao C, Vedanarayanan V, Ehrlich M (2004) Cytogenetic and immuno-FISH analysis of the $4 \mathrm{q}$ subtelomeric region, which is associated with facioscapulohumeral muscular dystrophy. Chromosoma 112: 350-9.

45. Dennis G Jr et al. (2003) DAVID: Database for Annotation, Visualization, and Integrated Discovery. Genome Biol 4: R60. 


\section{Legend to Figures}

Figure 1. Validation of the expression of the chemokines through RT-PCR. The expression levels of CXCL9, CXCL10 and CXCL11 were calculated relative to the mean value from normal controls in function of residual number of D4Z4. (A) In affected patients, the rank correlations are: 1.000* (CXCL9), 1.000* (CXCL10) and 0.800*** (CXCL11); while the line correlations are: 0.933** (CXCL9), 0.730*** (CXCL10) and $0.805^{* * *}$ (CXCL11). (B) In asymptomatic carriers, the rank correlations are: $-0,464 * * *$ (CXCL9), $-0.564 * * *$ (CXCL10) and $-0.527 * * *$ (CXCL11); while the line correlations are: $-0.595 * * *$ (CXCL9), $-0,004 * * *$ (CXCL10) and $-0.191 * * *$ (CXCL11).*p $<0.0001$; $* * \mathrm{p}=0.07 ; * * * \mathrm{p}>0.1$.

Figure 2. Relative expression of the other genes validated through RT-PCR in function of the number of $\mathrm{D4Z4}$ repeats. The calculated correlation coefficients for the expression level and the number of repeats for STATH (A) in affected patient are $0.8000^{* * *}$ (rank) and $0.2645 * * *$ (line) and in asymptomatic carrier are $-0.7537 * *$ (rank) and $-0.4417^{* * *}$ (line); for LOC91431 (B) in affected patient are $0.2000^{* * *}$ (rank) and $0.6908 * * *$ (line) and in asymptomatic carrier are $-0.8208 * *$ (rank) and $-0.8280 * *$ (line); for LPP (C) in affected patient are 1.000* (rank) and $0.7503^{* * *}$ (line) and in asymptomatic carrier are $-0.6669 * * *$ (rank) and $-0.7650 * * *$ (line); for PRIC285 in affected patient are $0.2000 * * *$ (rank) and $-0.1361 * * *$ (line) and in asymptomatic carrier are $0.5643 * * *$ (rank) and $0.4008 * * *$ (line). $* \mathrm{p}<0.0001 ; * * \mathrm{p}=0.08 ; * * * \mathrm{p}>0.1$. 


\section{Fig1}

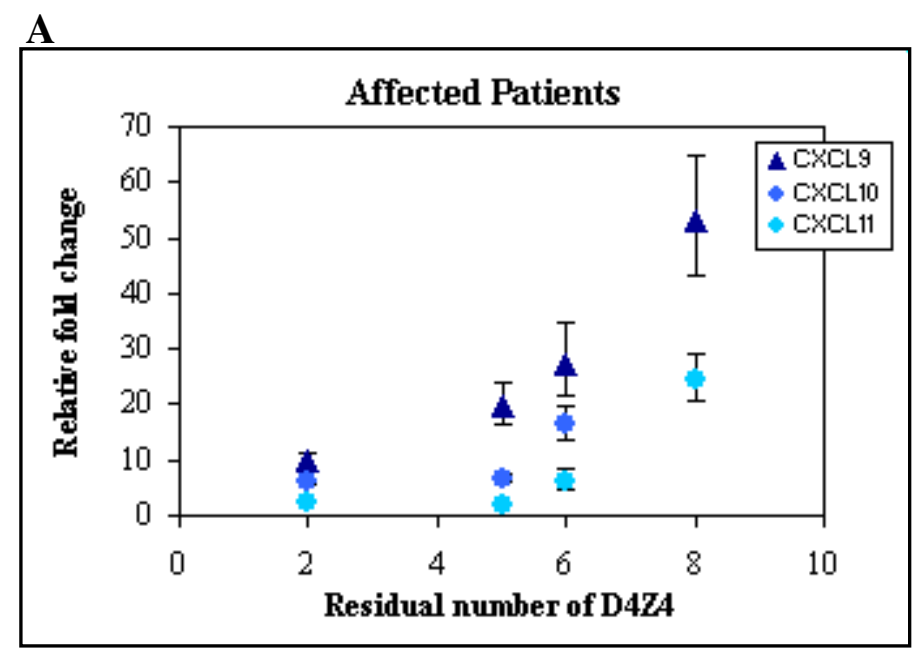

B

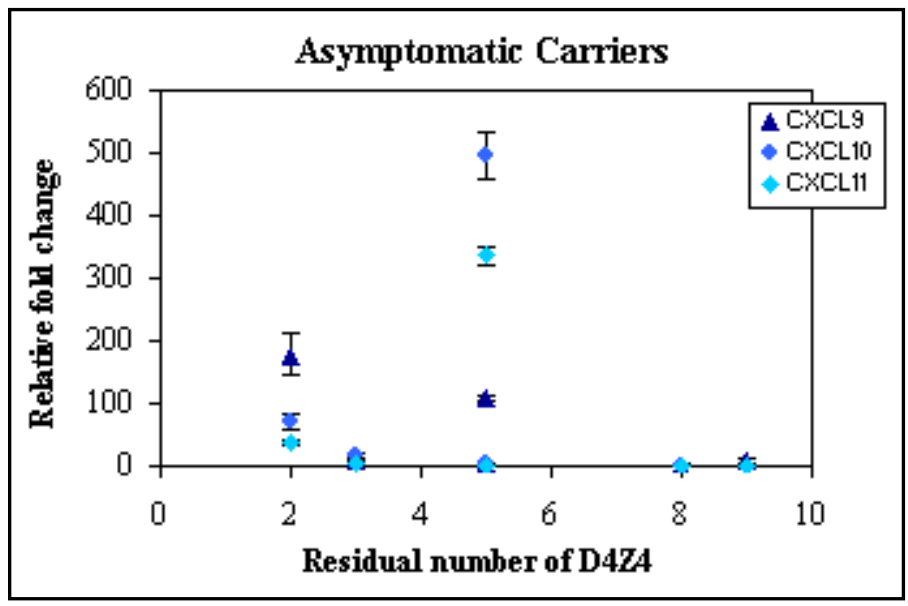


Fig2.

A

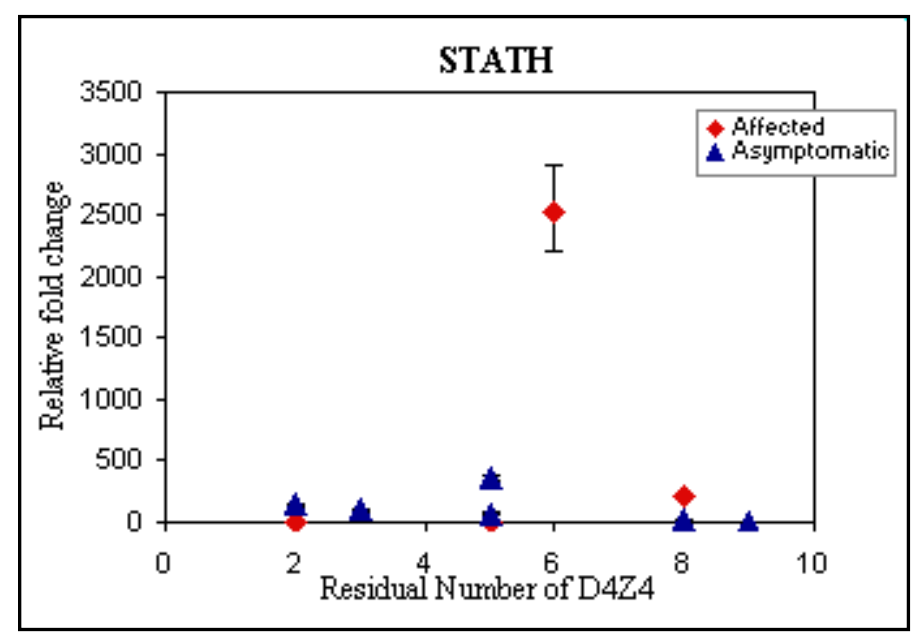

B

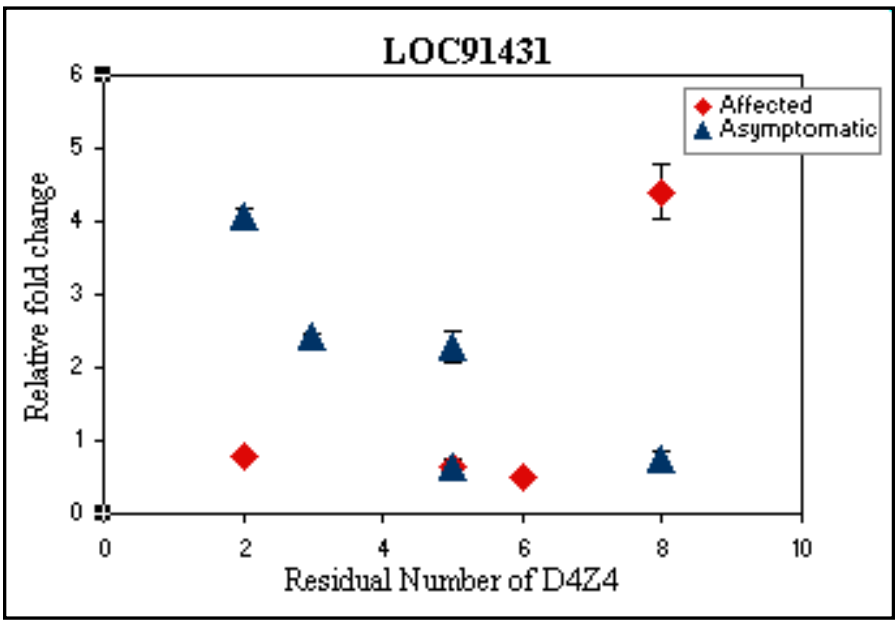




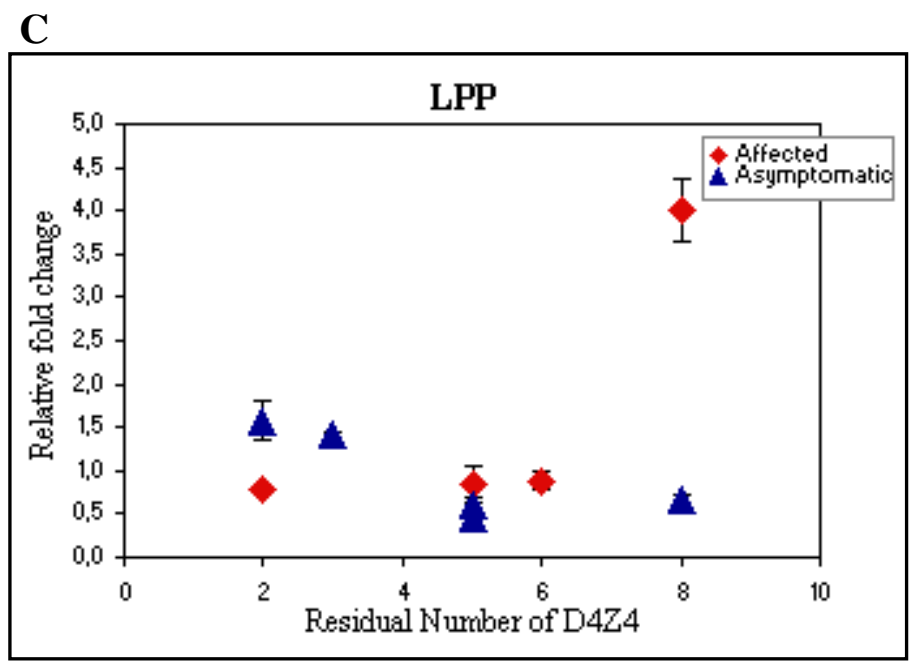

D

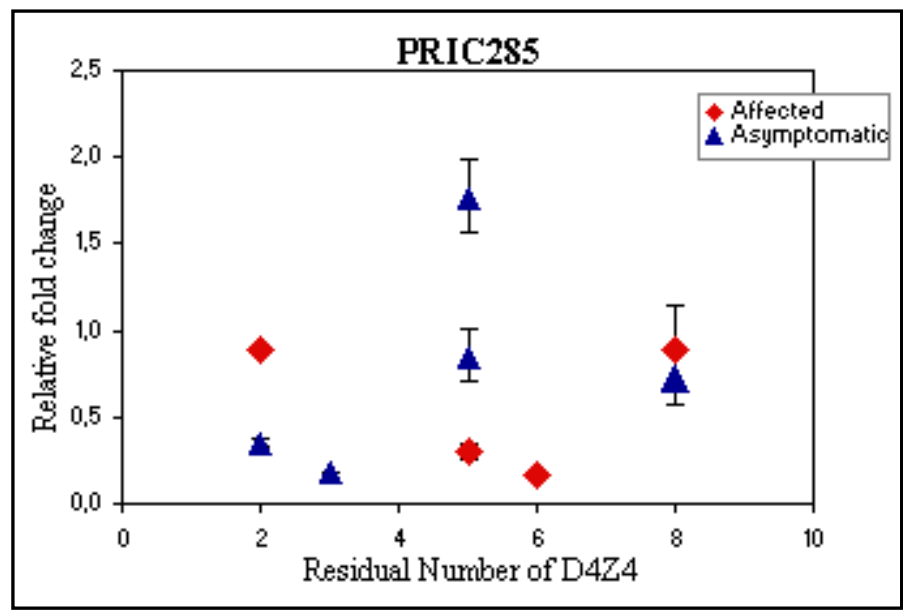


Table 1. Expression fold-changes of significantly dysregulated genes in asymptomatic vs control. Underlined fold-changes represent those deemed significant.

\begin{tabular}{|c|c|c|c|c|c|}
\hline Probe Set & Gene & Loci & $\begin{array}{l}\text { Fold Change } \\
\text { (asy/cont) }\end{array}$ & $\begin{array}{l}\text { Fold Change } \\
\text { (asy/aff) }\end{array}$ & $\begin{array}{l}\text { Fold Change } \\
\text { (aff/cont) }\end{array}$ \\
\hline 217022_s_at & IGHAI & $14 q 32.33$ & $\underline{13.85}$ & 0.69 & $\underline{19.98}$ \\
\hline 203915_at & CXCL9 & $4 q 21$ & $\underline{11.44}$ & 1.85 & 6.19 \\
\hline 211122_s_at & CXCL11 & $4 \mathrm{q} 21.2$ & $\underline{10.66}$ & $\underline{8.52}$ & 1.25 \\
\hline 210163_at & CXCL11 & $4 \mathrm{q} 21.2$ & $\underline{8.91}$ & $\underline{12.13}$ & 0.73 \\
\hline 205890_s_at & $U B D$ & $6 \mathrm{p} 21.3$ & $\underline{8.60}$ & $\underline{8.13}$ & 1.06 \\
\hline 1557690_x_at & NPAS2 & $2 \mathrm{q} 11.2$ & $\underline{4.62}$ & $\underline{4.99}$ & 0.92 \\
\hline 1558340_at & $D I X D C 1$ & $11 \mathrm{q} 23.1$ & $\underline{4.00}$ & $\underline{5.16}$ & 0.78 \\
\hline 1565935_at & LOC91431 & $4 q 25$ & $\underline{3.98}$ & $\underline{4.65}$ & 0.86 \\
\hline 216968_at & MASP2 & 1p36.3-p36.2 & $\underline{3.98}$ & $\underline{4.60}$ & 0.87 \\
\hline 228230_at & PRIC285 & $20 \mathrm{q} 13.33$ & $\underline{3.95}$ & $\underline{4.32}$ & 0.91 \\
\hline 206835_at & STATH & $4 q 11-q 13$ & $\underline{3.92}$ & 3.11 & 1.26 \\
\hline 243874_at & $L P P$ & $3 q 28$ & $\underline{3.49}$ & $\underline{4.87}$ & 0.72 \\
\hline
\end{tabular}


Table 2. Gene ontology categories enriched in the set of differentially expressed genes ( $p$ $<0.05)$ ranked by the fold-enrichment.

\begin{tabular}{|c|c|}
\hline \multicolumn{2}{|l|}{ Affected vs Control } \\
\hline GO Category & $\begin{array}{c}\text { Fold } \\
\text { Enrichmen }\end{array}$ \\
\hline $\begin{array}{c}\text { histone acetyltransferase } \\
\text { binding }\end{array}$ & 80.6 \\
\hline $\begin{array}{l}\text { GPI anchor metabolic } \\
\text { process }\end{array}$ & 32.9 \\
\hline $\begin{array}{l}\text { Glycosylphosphatidylinositol } \\
\text { (GPI)-anchor biosynthesis }\end{array}$ & 32.3 \\
\hline $\begin{array}{l}\text { phosphoinositide metabolic } \\
\text { process }\end{array}$ & 16.7 \\
\hline lipoprotein metabolic process & 13.4 \\
\hline $\begin{array}{l}\text { glycerophospholipid } \\
\text { metabolic process }\end{array}$ & 12.2 \\
\hline $\begin{array}{l}\text { Glycan structures - } \\
\text { biosynthesis } 2\end{array}$ & 11.1 \\
\hline $\begin{array}{l}\text { membrane lipid biosynthetic } \\
\text { process }\end{array}$ & 9.5 \\
\hline nucleolus & 7.0 \\
\hline $\begin{array}{l}\text { membrane lipid metabolic } \\
\text { process }\end{array}$ & 6.0 \\
\hline cell adhesion & 5.3 \\
\hline $\begin{array}{l}\text { intracellular non-membrane- } \\
\text { bound organelle }\end{array}$ & 2.1 \\
\hline $\begin{array}{l}\text { non-membrane-bound } \\
\text { organelle }\end{array}$ & 2.1 \\
\hline \multicolumn{2}{|l|}{ Asymptomatic vs Control } \\
\hline GO Category & $\begin{array}{c}\text { Fold } \\
\text { Enrichmen }\end{array}$ \\
\hline CXC chemokine & 190.8 \\
\hline Small chemokine, $\mathrm{C}-\mathrm{X}-\mathrm{C}$ & 153.4 \\
\hline $\begin{array}{l}\text { Small chemokine, } \\
\text { interleukin-8-like }\end{array}$ & 65.2 \\
\hline chemokine activity & 58.8 \\
\hline chemokine receptor binding & 57.6 \\
\hline inflammatory response & 51.1 \\
\hline SCY & 46.8 \\
\hline $\begin{array}{l}\text { G-protein-coupled receptor } \\
\text { binding }\end{array}$ & 38.4 \\
\hline locomotory behavior & 20.2 \\
\hline
\end{tabular}




\begin{tabular}{|c|c|}
\hline inflammatory response & 12.8 \\
\hline behavior & 12.0 \\
\hline response to wounding & 9.0 \\
\hline immune response & 8.4 \\
\hline immune system process & 6.3 \\
\hline Secreted & 4.9 \\
\hline Direct protein sequencing & 3.7 \\
\hline \multicolumn{2}{|l|}{ Affected vs Asymptomatic } \\
\hline GO Category & $\begin{array}{c}\text { Fold } \\
\text { Enrichment }\end{array}$ \\
\hline $\begin{array}{l}\text { ligase activity, forming } \\
\text { phosphoric ester bonds }\end{array}$ & 48.1 \\
\hline $\begin{array}{l}\text { double-stranded RNA } \\
\text { binding }\end{array}$ & 18.2 \\
\hline $\begin{array}{l}\text { domain:Helix-loop-helix } \\
\text { motif }\end{array}$ & 7.9 \\
\hline $\begin{array}{c}\text { Basic helix-loop-helix } \\
\text { dimerisation region bHLH }\end{array}$ & 7.4 \\
\hline $\begin{array}{l}\text { Helix-loop-helix DNA- } \\
\text { binding }\end{array}$ & 6.9 \\
\hline $\mathrm{HLH}$ & 6.8 \\
\hline $\begin{array}{l}\text { DNA-binding region:Basic } \\
\text { motif }\end{array}$ & 6.3 \\
\hline immune response & 6.0 \\
\hline $\begin{array}{c}\text { membrane lipid biosynthetic } \\
\text { process }\end{array}$ & 5.2 \\
\hline $\begin{array}{l}\text { compositionally biased } \\
\text { region:Pro-rich }\end{array}$ & 2.8 \\
\hline immune response & 2.8 \\
\hline rna-binding & 2.5 \\
\hline immune system process & 2.4 \\
\hline RNA binding & 2.3 \\
\hline defense response & 2.2 \\
\hline
\end{tabular}


Table 3. Expression fold-change in affected and asymptomatic carriers relative to healthy controls*

\begin{tabular}{|ccc|}
\hline Gene & $\begin{array}{c}\text { Fold change } \\
\text { Affected }\end{array}$ & $\begin{array}{c}\text { Fold change } \\
\text { Asymptomatics }\end{array}$ \\
\hline CXCL9 & 14.1 & 137.8 \\
CXCL10 & 6.4 & $(113.5-167.4)$ \\
& $(5.5-7.4)$ & 186.9 \\
CXCL11 & 2.1 & $1154.7-225.8)$ \\
& $(1.7-2.5)$ & $(102.7-126.2)$ \\
STATH & 2.4 & 225.4 \\
& $(2.0-2.8)$ & $(206.2-246.2)$ \\
LOC91431 & 0.7 & 3.0 \\
& $(0.6-0.8)$ & $(2.8-3.3)$ \\
PRIC285 & 0.5 & 0.8 \\
& $(0.4-0.6)$ & $(0.7-0.9)$ \\
LPP & 0.8 & 1.0 \\
& $(0.7-1.0)$ & $(0.8-1.1)$ \\
\hline
\end{tabular}

*Only the samples analyzed on microarrays were considered 


\section{Supporting Information}

Files in this Data Supplement:

SI Table 4

SI Table 5

SI Table 6

SI Table 7

SI Table 8

SI Table 9

SI Table 10

SI Table 11

SI Figure 3

SI Figure 3

Fig.3. Muscle tissues from biopsies stained with hematoxylin \& eosin, in which we can observe non-specific histological features of muscular dystrophy, such as variability of fiber sizes with atrophy, centralized nuclei, spliting, fibrosis in affected patient (A); and relatively normal histology in asymptomatic carrier (B) and normal control (C). 


\section{SI Text}

\section{RNA isolation}

The muscle tissue was ground into fine powder in dry ice. Then, $6 \mathrm{~mL}$ of TRIReagent was added, homogenized for 1 minute and the homogenate was split into 4 different tubes. After the incubation for 5 minutes, $300 \mu \mathrm{L}$ of chloroform was added and the solution was shaken vigorously for 1 minute. They were incubated for 15 minutes at room temperature and then centrifuged at $12,000 \mathrm{~g}$ for 15 minutes at $4^{\circ} \mathrm{C}$. The supernatant was transferred to a fresh tube, $750 \mu \mathrm{L}$ of isopropanol was added and mixed. After the incubation for 10 minutes at room temperature, the solution was centrifuged at $12,000 \mathrm{~g}$ for 15 minutes at $4^{\circ} \mathrm{C}$ for RNA precipitation. The RNA pellets from the 4 tubes were mixed and washed with $1 \mathrm{~mL} 75 \%$ ethanol. The pellets were resuspended in nuclease-free water, mixed by pipettation, and incubated at $55^{\circ} \mathrm{C}$ for 15 minutes. The RNA quality was observed through gel electrophoresis and Experion (Bio-Rad, Hercules, CA).

\section{Microarray Data Analysis}

Each sample transcriptome profile is regarded as a 54,675-dimensional vector of measured probe expression signals. There were a total of 15 individual sample profiles: 5 control, 5 asymptomatic, 5 affected. Asymptomatic sample \#14 was excluded from subsequent analysis since less than $5 \%$ of its total probes had a "Present" Affymetrix detection call.

The entire dataset was normalized sample-wise by linear regression to the reference sample with the highest average linear correlation against all other samples. This reference sample was Control sample \#3.

A probe-by-probe differential fold analysis was performed between any 2 sample populations - control vs asymptomatic, control vs. affected, asymptomatic vs. affected using a geometric logarithmic fold method on the normalized dataset with the minimal probe signal threshold set to $50(1,2)$. The difference in average logarithmic signals (abbreviated AvgLF) of a microarray probe/gene between the 2 sample populations was 
calculated. If a given probe has normalized signals $50 \leq \mathrm{a} 1 \leq \mathrm{a} 2 \leq \ldots \leq \mathrm{aJ}$ and $50 \leq \mathrm{b} 1 \leq$ $\mathrm{b} 2 \leq \ldots \leq \mathrm{bK}$ in populations $\mathrm{A}$ and $\mathrm{B}$ respectively, then AvgLF of $\mathrm{B}$ relative to $\mathrm{A}$ is defined as mean $\left(\log \left(b^{\prime} s\right)\right)$ - mean $(\log (a ' s))$. Furthermore, we define NoisLF as the maximal difference in logarithmic signals from a common population. In this example, NoisLF for the probe in A is mean $(\log (\mathrm{aJ} 2))$ - mean $(\log (\mathrm{aJ} 1))$ where $\mathrm{J} 1$ ranges from 1 to $[\mathrm{J} / 2], \mathrm{J} 2$ range from $[\mathrm{J} / 2]+1$ to $\mathrm{J}$ (if $\mathrm{J}$ is even) or $[\mathrm{J} / 2]+2$ to $\mathrm{J}$ (if $\mathrm{J}$ is odd), where [J/2] is the largest integer less than or equal to $J / 2$. An AvgLF value for a probe is considered significant if its magnitude exceeds $\log (2)$ and the NoisLF from all 3 sample populations. 12 probes (11 unique genes) were significantly differentially expressed across control asymptomatic, 56 probes (56 unique genes) control - affected, and 147 probes (140 unique genes) asymptomatic - affected by this criterion.

1. Haslett JN et al. (2002) Gene expression comparison of biopsies from Duchenne muscular dystrophy (DMD) and normal skeletal muscle. Proc Natl Acad Sci USA 99(23): 15000-05.

2. Zhao Q et al. (2002) Identification of genes expressed with temporal-spatial restriction to developing cerebellar neuron precursors by a functional genomic approach. Proc Natl Acad Sci USA 99(8): 5704-09. 
Table 4. Expression fold-changes of significantly upregulated genes in affected vs asymptomatic

\begin{tabular}{|cccc|}
\hline Probe Set & Symbol & Loci & $\begin{array}{c}\text { Fold Change } \\
\text { (Affected/Asymptomatic) }\end{array}$ \\
\hline 204639_at & ADA & 20q12-q13.11 & 4,17 \\
208937_s_at & ID1 & $20 \mathrm{q} 11$ & 3,80 \\
227337_at & ANKRD37 & $4 \mathrm{q} 35.1$ & 3,35 \\
209118_s_at & TUBA3 & $12 \mathrm{q} 12-12 \mathrm{q} 14.3$ & 2,97 \\
223391_at & SGPP1 & $14 \mathrm{q} 23.2$ & 2,61 \\
202458_at & PRSS23 & $11 \mathrm{q} 14.1$ & 2,60 \\
44783_s_at & HEY1 & $8 \mathrm{q} 21$ & 2,58 \\
219197_s_at & SCUBE2 & $11 \mathrm{p} 15.3$ & 2,40 \\
226077_at & FLJ31951 & 5q33.3 & 2,40 \\
200947_s_at & GLUD1 & $10 \mathrm{q} 23.3$ & 2,35 \\
205794_s_at & NOVA1 & $14 \mathrm{q}$ & 2,24 \\
224827_at & UBTD2 & 5q35.1 & 2,20 \\
227029_at & C14orf24 & $14 \mathrm{q} 13.2$ & 2,08 \\
\hline
\end{tabular}

Table 5. Expression fold-changes of significantly downregulated genes in affected vs asymptomatic

\begin{tabular}{|cccc|}
\hline Probe Set & Symbol & Loci & $\begin{array}{c}\text { Fold Change } \\
\text { (Affected/Asymptomatic) }\end{array}$ \\
\hline 210163_at & CXCL11 & $4 \mathrm{q} 21.2$ & 0,08 \\
240453_at & C20orf26 & $20 \mathrm{p} 11.23$ & 0,09 \\
210797_s_at & OASL & $12 \mathrm{q} 24.2$ & 0,09 \\
1560750_at & LOC151121 & $2 \mathrm{q} 21.1$ & 0,09 \\
230331_at & LOC196541 & $13 \mathrm{q} 33.1$ & 0,09 \\
1569112_at & SLC44A5 & $1 \mathrm{p} 31.1$ & 0,09 \\
1552779_a_at & SLC44A5 & $1 \mathrm{p} 31.1$ & 0,11 \\
227262_at & HAPLN3 & $15 \mathrm{q} 26.1$ & 0,12 \\
220340_at & KIAA1772 & $18 \mathrm{q} 11.1-\mathrm{q} 11.2$ & 0,12 \\
211122_s_at & CXCL11 & $4 \mathrm{q} 21.2$ & 0,12 \\
205890_s_at & UBD & $6 \mathrm{p} 21.3$ & 0,12 \\
1558705_at & ATOH8 & 2p11.2 & 0,12 \\
244106_at & KCNQ5 & $6 \mathrm{q} 14$ & 0,13 \\
235504_at & GREM2 & $1 \mathrm{q} 43$ & 0,13 \\
239465_at & UQCRC2 & $16 \mathrm{p} 12$ & 0,14 \\
205660_at & OASL & $12 \mathrm{q} 24.2$ & 0,14 \\
\hline
\end{tabular}




\begin{tabular}{|c|c|c|c|}
\hline 233613_x_at & REXO2 & $11 \mathrm{q} 23.1-\mathrm{q} 23.2$ & 0,14 \\
\hline 236108_at & KIAA1632 & $18 \mathrm{q} 12.3-\mathrm{q} 21.1$ & 0,15 \\
\hline 211807_x_at & PCDHGB5 & $5 q 31$ & 0,15 \\
\hline 232469_x_at & SSBP3 & $1 \mathrm{p} 32.3$ & 0,15 \\
\hline 217141_at & BTBD7 & $14 \mathrm{q} 32.12-\mathrm{q} 32.13$ & 0,15 \\
\hline 1553015_a_at & RECQL4 & $8 \mathrm{q} 24.3$ & 0,15 \\
\hline 233059_at & $\mathrm{KCNJ} 3$ & $2 \mathrm{q} 24.1$ & 0,15 \\
\hline 232961_at & DNAPTP6 & $2 q 33.1$ & 0,15 \\
\hline 241824_at & FOSL2 & $2 \mathrm{p} 23.3$ & 0,15 \\
\hline 244670_at & CDKL1 & $14 \mathrm{q} 22.1$ & 0,16 \\
\hline 208159_x_at & DDX11 & $12 \mathrm{p} 11$ & 0,16 \\
\hline 1555385_at & B4GALNT1 & $12 \mathrm{q} 13.3$ & 0,16 \\
\hline 235157_at & PARP14 & $3 q 21.1$ & 0,16 \\
\hline 222833_at & AYTL1 & $16 \mathrm{q} 12.2$ & 0,16 \\
\hline 210536_s_at & SPAM1 & $7 \mathrm{q} 31.3$ & 0,16 \\
\hline 1570227_at & COQ9 & $16 q 13$ & 0,17 \\
\hline 211194_s_at & TP73L & $3 q 28$ & 0,17 \\
\hline 214671_s_at & $\mathrm{ABR}$ & $17 \mathrm{p} 13.3$ & 0,17 \\
\hline 215159_s_at & NADK & $1 \mathrm{p} 36.33-\mathrm{p} 36.21$ & 0,17 \\
\hline 221010_s_at & SIRT5 & $6 \mathrm{p} 23$ & 0,17 \\
\hline 210443_x_at & OGFR & $20 \mathrm{q} 13.3$ & 0,17 \\
\hline 1553992_s_at & NBR2 & $17 \mathrm{q} 21$ & 0,17 \\
\hline 205067_at & IL1B & $2 q 14$ & 0,17 \\
\hline 236897_at & IL17RB & $3 \mathrm{p} 21.1$ & 0,17 \\
\hline 238627_at & TRAPPC2L & $16 \mathrm{q} 24.3$ & 0,17 \\
\hline 229377_at & GRTP1 & $13 q 34$ & 0,17 \\
\hline 207348_s_at & LIG3 & $17 q 11.2-q 12$ & 0,17 \\
\hline 233251_at & STRBP & $9 q 33.3$ & 0,17 \\
\hline 233959_at & LOC221442 & $6 \mathrm{p} 21.1$ & 0,18 \\
\hline 239373_at & ARFGEF2 & $20 q 13.13$ & 0,18 \\
\hline 1557595_at & GINS2 & $16 \mathrm{q} 24.1$ & 0,18 \\
\hline 207306_at & TCF15 & 20 p13 & 0,18 \\
\hline 233981_at & RCL1 & $9 \mathrm{p} 24.1-\mathrm{p} 23$ & 0,18 \\
\hline 238628_s_at & TRAPPC2L & $16 \mathrm{q} 24.3$ & 0,18 \\
\hline 39248_at & AQP3 & $9 \mathrm{p} 13$ & 0,18 \\
\hline 1569930_at & DCUN1D4 & $4 q 12$ & 0,18 \\
\hline 232311_at & $\mathrm{B} 2 \mathrm{M}$ & $15 q 21-\mathrm{q} 22.2$ & 0,19 \\
\hline 207735_at & RNF125 & $18 \mathrm{q} 12.1$ & 0,19 \\
\hline 233992_x_at & ZNF445 & $3 \mathrm{p} 21.32$ & 0,19 \\
\hline 229617_x_at & AP2A1 & $19 q 13.33$ & 0,19 \\
\hline 1552326_a_at & CCDC11 & $18 \mathrm{q} 21.1$ & 0,19 \\
\hline 243682_at & NCOR1 & $17 \mathrm{p} 11.2$ & 0,19 \\
\hline 217282_at & MAN1A2 & $1 \mathrm{p} 13$ & 0,19 \\
\hline 236913_at & C17orf45 & $17 \mathrm{p} 11.2$ & 0,19 \\
\hline 220476_s_at & C1orf183 & $1 \mathrm{p} 13.2$ & 0,19 \\
\hline 232767_at & IGSF4 & $11 \mathrm{q} 23.2$ & 0,19 \\
\hline 231985_at & MICAL3 & $22 q 11.21$ & 0,19 \\
\hline
\end{tabular}




\begin{tabular}{|c|c|c|c|}
\hline 232612_s_at & ATG16L1 & $2 q 37.1$ & 0,19 \\
\hline 213889_at & PIGL & 17p12-p11.2 & 0,19 \\
\hline 216629_at & SRRM2 & $16 \mathrm{p} 13.3$ & 0,19 \\
\hline 203276_at & LMNB1 & $5 \mathrm{q} 23.3-\mathrm{q} 31.1$ & 0,19 \\
\hline 1558340_at & DIXDC1 & $11 \mathrm{q} 23.1$ & 0,19 \\
\hline 1555464_at & IFIH1 & 2p24.3-q24.3 & 0,20 \\
\hline 229286_at & MAGEE1 & Xq13.3 & 0,20 \\
\hline 200879_s_at & EPAS1 & 2p21-p16 & 0,20 \\
\hline 207978_s_at & NR4A3 & $9 q 22$ & 0,20 \\
\hline 223859_at & EPB41L4B & $9 q 31-q 32$ & 0,20 \\
\hline 238594_x_at & DUSP8 & $11 \mathrm{p} 15.5$ & 0,20 \\
\hline 211818_s_at & PDE4C & 19 p13.11 & 0,20 \\
\hline 205714_s_at & ZMYND10 & $3 p 21.3$ & 0,20 \\
\hline 1557690_x_at & NPAS2 & $2 q 11.2$ & 0,20 \\
\hline 213748_at & TRIM66 & $11 \mathrm{p} 15.4$ & 0,20 \\
\hline 1565759_at & RPL13 & $16 \mathrm{q} 24.3117 \mathrm{p} 11.2$ & 0,20 \\
\hline 225777_at & C9orf140 & $9 \mathrm{q} 34.3$ & 0,20 \\
\hline 227513_s_at & LRRFIP1 & $2 q 37.3$ & 0,21 \\
\hline 243874_at & LPP & $3 q 28$ & 0,21 \\
\hline 1568702_a_at & WDR71 & $11 \mathrm{q} 13.4$ & 0,21 \\
\hline 214095_at & SHMT2 & $12 q 12-q 14$ & 0,21 \\
\hline 211135_x_at & LILRB2 & $19 \mathrm{q} 13.4$ & 0,21 \\
\hline 232629_at & PROK2 & $3 \mathrm{p} 21.1$ & 0,21 \\
\hline 236274_at & EIF3S9 & $7 \mathrm{p} 22.2$ & 0,21 \\
\hline 222963_s_at & IL1RAPL1 & Xp22.1-p21.3 & 0,21 \\
\hline 207319_s_at & CDC2L5 & $7 \mathrm{p} 13$ & 0,21 \\
\hline 203439_s_at & STC2 & $5 q 35.2$ & 0,21 \\
\hline 1565935_at & LOC91431 & $4 q 25$ & 0,22 \\
\hline 1570414_x_at & FLJ13197 & $4 \mathrm{p} 14$ & 0,22 \\
\hline 224556_s_at & LHX6 & $9 \mathrm{q} 33.2$ & 0,22 \\
\hline 216968_at & MASP2 & 1p36.3-p36.2 & 0,22 \\
\hline 213403_at & MGC11332 & $2 q 12.1$ & 0,22 \\
\hline 215607_x_at & SMEK1 & $14 q 32.12$ & 0,22 \\
\hline 235776_x_at & LOC389772 & - & 0,22 \\
\hline 238127_at & GAS6 & $13 q 34$ & 0,22 \\
\hline 1564242_at & TRPM2 & $21 \mathrm{q} 22.3$ & 0,22 \\
\hline 237583_at & LOC399978 & $11 \mathrm{q} 24.3$ & 0,22 \\
\hline 232319_at & GGPS1 & $1 \mathrm{q} 43$ & 0,22 \\
\hline 238581_at & GBP5 & $1 \mathrm{p} 22.2$ & 0,23 \\
\hline 206356_s_at & GNAL & $18 \mathrm{p} 11.22-\mathrm{p} 11.21$ & 0,23 \\
\hline 232588_at & STAG1 & $3 q 22.3$ & 0,23 \\
\hline 220873_at & REPS2 & $\mathrm{Xp} 22.2$ & 0,23 \\
\hline 234525_at & DKFZP761C1711 & - & 0,23 \\
\hline 216026_s_at & POLE & $12 \mathrm{q} 24.3$ & 0,23 \\
\hline 228230_at & PRIC285 & $20 q 13.33$ & 0,23 \\
\hline 1565436_s_at & MLL & $11 \mathrm{q} 23$ & 0,23 \\
\hline 213006_at & CEBPD & 8p11.2-p11.1 & 0,23 \\
\hline
\end{tabular}




\begin{tabular}{|cccc|}
\hline 1570541_s_at & LOC400759 & $1 \mathrm{p} 22.2$ & 0,23 \\
214511_x_at & FCGR1A & $1 \mathrm{q} 21.2-\mathrm{q} 21.3$ & 0,23 \\
219324_at & NOL12 & $22 \mathrm{q} 13.1$ & 0,24 \\
240509_s_at & GREM2 & $1 \mathrm{q} 43$ & 0,24 \\
212523_s_at & KIAA0146 & $8 \mathrm{q} 11.21$ & 0,24 \\
232711_at & PKNOX2 & $11 \mathrm{q} 24.2$ & 0,24 \\
228439_at & BATF2 & $11 \mathrm{q} 13.1$ & 0,24 \\
213983_s_at & SCC-112 & $4 \mathrm{p} 14$ & 0,24 \\
222595_s_at & DIDO1 & $20 \mathrm{q} 13.33$ & 0,24 \\
39549_at & NPAS2 & $2 \mathrm{q} 11.2$ & 0,24 \\
207999_s_at & ADARB1 & $21 \mathrm{q} 22.3$ & 0,25 \\
223820_at & RBP5 & $12 \mathrm{p} 13.31$ & 0,25 \\
204769_s_at & TAP2 & $6 \mathrm{p} 21.3$ & 0,25 \\
227675_at & LRSAM1 & $9 \mathrm{q} 33.3-\mathrm{q} 34.11$ & 0,26 \\
219776_s_at & FLJ11125 & $8 \mathrm{p} 21.2$ & 0,26 \\
206610_s_at & F11 & $4 \mathrm{q} 35$ & 0,27 \\
220097_s_at & TMEM104 & $17 \mathrm{q} 25.1$ & 0,28 \\
232753_at & ZNF346 & $5 \mathrm{q} 35.2$ & 0,28 \\
222937_s_at & MMP28 & $17 \mathrm{q} 11-\mathrm{q} 21.1$ & 0,28 \\
226130_at & LOC441876 & $1 \mathrm{p} 36.21$ & 0,29 \\
204918_s_at & MLLT3 & $9 \mathrm{p} 22$ & 0,30 \\
238919_at & PCDH9 & $13 \mathrm{q} 14.3-\mathrm{q} 21.1$ & 0,34 \\
51146_at & PIGV & $1 \mathrm{p} 36.11$ & 0,35 \\
206561_s_at & AKR1B10 & $7 \mathrm{q} 33$ & 0,49 \\
\hline
\end{tabular}


Table 6. Expression fold-changes of significantly upregulateed genes in affected $\mathrm{x}$ control

\begin{tabular}{|c|c|c|c|}
\hline Probe Set & Symbol & Loci & $\begin{array}{c}\text { Fold Change } \\
\text { (Affected/Control) }\end{array}$ \\
\hline 217022_s_at & IGHA1 & $14 q 32.33$ & 19,98 \\
\hline 206717_at & MYH8 & $17 \mathrm{p} 13.1$ & 6,41 \\
\hline 213247_at & SVEP1 & $9 q 32$ & 5,73 \\
\hline 213502_x_at & LOC91316 & $22 \mathrm{q} 11.23$ & 5,20 \\
\hline 226818_at & MPEG1 & $11 \mathrm{q} 12.1$ & 4,06 \\
\hline 229800_at & DCAMKL1 & $13 q 13$ & 3,96 \\
\hline 202149_at & NEDD9 & $6 p 25-p 24$ & 3,11 \\
\hline 232304_at & PELI1 & $2 \mathrm{p} 13.3$ & 3,02 \\
\hline 1557905_s_at & $\mathrm{CD} 44$ & $11 \mathrm{p} 13$ & 2,98 \\
\hline 205794_s_at & NOVA1 & $14 q$ & 2,94 \\
\hline 226621_at & OSMR & $5 \mathrm{p} 13.1$ & 2,91 \\
\hline 217478_s_at & HLA-DMA & $6 \mathrm{p} 21.3$ & 2,85 \\
\hline 203088_at & FBLN5 & $14 \mathrm{q} 32.1$ & 2,67 \\
\hline 221031_s_at & APOLD1 & $12 \mathrm{p} 13.1$ & 2,44 \\
\hline 212412_at & PDLIM5 & $4 q 22$ & 2,36 \\
\hline 201005_at & CD9 & $12 \mathrm{p} 13.3$ & 2,23 \\
\hline 222816_s_at & $\mathrm{ZCCHC} 2$ & $18 \mathrm{q} 21.33$ & 2,21 \\
\hline 225464_at & FRMD6 & $14 q 22.1$ & 2,12 \\
\hline 208319_s_at & RBM3 & $\mathrm{Xp} 11.2$ & 2,02 \\
\hline 214946_x_at & FAM21C & $10 \mathrm{q} 11.1$ & 2,00 \\
\hline
\end{tabular}


Table 7. Expression fold-changes of significantly downregulated genes in affected $x$ control

\begin{tabular}{|c|c|c|c|}
\hline Probe Set & Symbol & Loci & $\begin{array}{c}\text { Fold Change } \\
\text { (Affected/Control) }\end{array}$ \\
\hline 230331_at & LOC196541 & $13 \mathrm{q} 33.1$ & 0,04 \\
\hline 232185_at & C20orf132 & $20 q 11.22$ & 0,15 \\
\hline 1558331_at & SIRT2 & $19 q 13$ & 0,16 \\
\hline 243816_at & ZNF70 & $22 \mathrm{q} 11.2 \mathrm{|} 22 \mathrm{q} 11.23$ & 0,17 \\
\hline 208159_x_at & DDX11 & $12 \mathrm{p} 11$ & 0,17 \\
\hline 205232_s_at & PAFAH2 & $1 \mathrm{p} 34.3$ & 0,17 \\
\hline 229377_at & GRTP1 & $13 q 34$ & 0,17 \\
\hline 240016_at & SENP6 & 6q13-q14.3 & 0,17 \\
\hline 214095_at & SHMT2 & $12 q 12-q 14$ & 0,17 \\
\hline 219241_x_at & SSH3 & $11 \mathrm{q} 13.1$ & 0,17 \\
\hline 216026_s_at & POLE & $12 \mathrm{q} 24.3$ & 0,18 \\
\hline 213889_at & PIGL & 17p12-p11.2 & 0,18 \\
\hline 215781_s_at & TOP3B & $22 q 11.22$ & 0,19 \\
\hline 1555385_at & B4GALNT1 & $12 \mathrm{q} 13.3$ & 0,19 \\
\hline 206395_at & DGKG & $3 q 27-q 28$ & 0,20 \\
\hline 232612_s_at & ATG16L1 & $2 q 37.1$ & 0,20 \\
\hline 215554_at & GPLD1 & $6 \mathrm{p} 22.3-\mathrm{p} 22.2$ & 0,20 \\
\hline 200879_s_at & EPAS1 & 2p21-p16 & 0,21 \\
\hline 219324_at & NOL12 & $22 \mathrm{q} 13.1$ & 0,23 \\
\hline 215099_s_at & RXRB & $6 \mathrm{p} 21.3$ & 0,23 \\
\hline 1570414_x_at & FLJ13197 & $4 \mathrm{p} 14$ & 0,24 \\
\hline 222595_s_at & DIDO1 & $20 q 13.33$ & 0,24 \\
\hline 211807_x_at & PCDHGB5 & $5 q 31$ & 0,24 \\
\hline 212996_s_at & URB1 & $21 \mathrm{q} 22.11$ & 0,24 \\
\hline 1558705_at & ATOH8 & $2 \mathrm{p} 11.2$ & 0,24 \\
\hline 215607_x_at & SMEK1 & $14 q 32.12$ & 0,24 \\
\hline 235983_at & TRAK2 & $2 q 33$ & 0,24 \\
\hline 213403_at & MGC11332 & $2 q 12.1$ & 0,25 \\
\hline 232469_x_at & SSBP3 & $1 \mathrm{p} 32.3$ & 0,26 \\
\hline 1568702_a_at & WDR71 & $11 \mathrm{q} 13.4$ & 0,26 \\
\hline 1570227_at & COQ9 & $16 q 13$ & 0,29 \\
\hline 233613_x_at & REXO2 & $11 \mathrm{q} 23.1-\mathrm{q} 23.2$ & 0,29 \\
\hline 232753_at & ZNF346 & $5 q 35.2$ & 0,30 \\
\hline
\end{tabular}




\begin{tabular}{|cccc|}
\hline 1565759_at & RPL13 & 16q24.3117p11.2 & 0,33 \\
51146_at & PIGV & $1 \mathrm{p} 36.11$ & 0,36 \\
238919_at & PCDH9 & 13q14.3-q21.1 & 0,40 \\
\hline
\end{tabular}

Table 8. Expression of genes from 4q35. Underlined fold-changes represent those deemed significant.

\begin{tabular}{|c|c|c|c|c|c|}
\hline Probe Set & Gene & Name & $\begin{array}{c}\text { Fold Change } \\
\text { (asy/cont) }\end{array}$ & $\begin{array}{l}\text { Fold Change } \\
\text { (asy/aff) }\end{array}$ & $\begin{array}{c}\text { Fold Change } \\
\text { (aff/cont) }\end{array}$ \\
\hline $\begin{array}{l}\text { 216473_x_at } \\
\text { 208201_at }\end{array}$ & $D U X 4$ & Double homeobox, 4 & no call & no call & no call \\
\hline 234830_at & FRG2 & $\begin{array}{c}\text { FSHD region gene } 2 \\
\text { protein }\end{array}$ & no call & no call & no call \\
\hline 204145_at & FRG1 & FSHD region gene 1 & $-1,07$ & $-1,08$ & 1,01 \\
\hline 235535_x_at & FRG1 & FSHD region gene 1 & 1,65 & 1,67 & $-1,01$ \\
\hline 206610_s_at & $F 11$ & Coagulation factor XI & 1,82 & $\underline{3,71}$ & $-2,04$ \\
\hline 210170_at & PDLIM3 & PDZ and LIM domain 3 & $-1,23$ & $-1,47$ & 1,19 \\
\hline 238592_at & PDLIM3 & PDZ and LIM domain 3 & $-1,08$ & $-1,23$ & 1,14 \\
\hline 209621_s_at & PDLIM3 & PDZ and LIM domain 3 & $-1,24$ & $-1,19$ & $-1,05$ \\
\hline 227337_at & ANKRD37 & Ankyrin repeat domain 37 & $-1,22$ & $\underline{-3,35}$ & 2,76 \\
\hline 202825_at & $A N T 1$ & Solute carrier family 25 & $-1,09$ & $-1,34$ & 1,23 \\
\hline
\end{tabular}


Table 9. Expression fold-change in affected and asymptomatic carriers relative to healthy controls*

\begin{tabular}{|ccc|}
\hline Gene & $\begin{array}{c}\text { Fold change }- \text { Affected } \\
(\mathbf{n}=\mathbf{4})\end{array}$ & $\begin{array}{c}\text { Fold change - Asymptomatic } \\
(\mathbf{n}=\mathbf{6})\end{array}$ \\
\hline \multirow{2}{*}{ CXCL9 } & 8.2 & 3.7 \\
& $(2.7-24.8)$ & $(0.8-18.1)$ \\
CXCL10 & 2.3 & 4.3 \\
& $(1.3-4.2)$ & $(0.6-31.7)$ \\
CXCL11 & 2.9 & 2.2 \\
& $(1.0-7.9)$ & $(0.3-14.2)$ \\
STATH & 386.0 & 501.8 \\
LOC91431 & $(22.6-6579.3)$ & $(142.0-1773.0)$ \\
& 1.5 & 2.0 \\
PRIC285 & $(0.5-4.6)$ & $(0.9-4.5)$ \\
& 0.5 & 0.7 \\
LPP & $(0.1-2.4)$ & $(0.2-2.6)$ \\
& 2.1 & $(0.6-4.3)$ \\
\hline
\end{tabular}

* Additional samples from affected and unrelated asymptomatic carriers were included in the analysis 
Table 10. Muscle specimens available for the study

\begin{tabular}{|c|c|c|c|c|c|c|c|c|c|}
\hline Family & Sample & Diagnosis & $\begin{array}{c}\text { Age/ Gender } \\
\text { (year) }\end{array}$ & $\begin{array}{l}\text { Onset } \\
\text { (year) }\end{array}$ & $\begin{array}{c}\mathrm{N}^{\circ} \mathrm{D4Z4} \\
\text { repeats }\end{array}$ & $\begin{array}{c}\text { Muscle } \\
\text { weakness }\end{array}$ & $\begin{array}{c}\text { Other } \\
\text { Features }\end{array}$ & $\begin{array}{c}\text { CK } \\
(\mathbf{I U} / \mathbf{I})\end{array}$ & Muscle \\
\hline 1 & $\begin{array}{l}1 \\
2 \\
3\end{array}$ & $\begin{array}{l}\text { Affected } \\
\text { Asymptomatic carrier } \\
\text { Normal control }\end{array}$ & $\begin{array}{l}49 / \mathrm{M} \\
69 / \mathrm{F} \\
41 / \mathrm{F}\end{array}$ & $\begin{array}{l}16 \\
- \\
-\end{array}$ & $\begin{array}{l}5 \\
5 \\
-\end{array}$ & $\begin{array}{l}\text { FSPA } \\
- \\
-\end{array}$ & $\begin{array}{l}- \\
-\end{array}$ & $\begin{array}{l}617.5 \\
\text { ND } \\
72.5\end{array}$ & $\begin{array}{l}\text { biceps } \\
\text { biceps } \\
\text { biceps }\end{array}$ \\
\hline 2 & $\begin{array}{l}4 \\
5 \\
6\end{array}$ & $\begin{array}{l}\text { Affected } \\
\text { Asymptomatic carrier } \\
\text { Normal control }\end{array}$ & $\begin{array}{l}30 / \mathrm{M} \\
66 / \mathrm{M} \\
38 / \mathrm{F}\end{array}$ & $\begin{array}{l}15 \\
- \\
-\end{array}$ & $\begin{array}{l}2 \\
2 \\
-\end{array}$ & $\begin{array}{l}\text { FSPA } \\
- \\
-\end{array}$ & $\begin{array}{l}\mathrm{H} \\
- \\
-\end{array}$ & $\begin{array}{l}11 \\
4 \\
2.9\end{array}$ & $\begin{array}{l}\text { deltoid } \\
\text { deltoid } \\
\text { deltoid }\end{array}$ \\
\hline 3 & $\begin{array}{l}7 \\
8 \\
9\end{array}$ & $\begin{array}{l}\text { Affected } \\
\text { Asymptomatic carrier } \\
\text { Normal control }\end{array}$ & $\begin{array}{l}14 / \mathrm{F} \\
32 / \mathrm{F} \\
35 / \mathrm{F}\end{array}$ & $\begin{array}{l}7 \\
- \\
-\end{array}$ & $\begin{array}{l}3 \\
3 \\
-\end{array}$ & $\begin{array}{l}\text { FS } \\
- \\
-\end{array}$ & $\begin{array}{l}\mathrm{D} \\
- \\
-\end{array}$ & $\begin{array}{l}94.5 \\
6.2 \\
81\end{array}$ & $\begin{array}{l}\text { deltoid } \\
\text { deltoid } \\
\text { deltoid }\end{array}$ \\
\hline 4 & $\begin{array}{l}10 \\
11 \\
12\end{array}$ & $\begin{array}{l}\text { Affected } \\
\text { Asymptomatic carrier } \\
\text { Normal control }\end{array}$ & $\begin{array}{l}11 / \mathrm{M} \\
54 / \mathrm{M} \\
16 / \mathrm{M}\end{array}$ & $\begin{array}{l}6 \\
- \\
-\end{array}$ & $\begin{array}{l}5 \\
5 \\
-\end{array}$ & $\begin{array}{l}\text { FSP } \\
- \\
-\end{array}$ & $\begin{array}{l}\mathrm{L} \\
- \\
-\end{array}$ & $\begin{array}{l}230.9 \\
8.6 \\
9.1\end{array}$ & $\begin{array}{l}\text { biceps } \\
\text { biceps } \\
\text { biceps }\end{array}$ \\
\hline 5 & $\begin{array}{l}13 \\
14 \\
15\end{array}$ & $\begin{array}{l}\text { Affected } \\
\text { Asymptomatic carrier } \\
\text { Normal control }\end{array}$ & $\begin{array}{l}38 / \mathrm{M} \\
57 / \mathrm{F} \\
39 / \mathrm{M}\end{array}$ & $\begin{array}{l}21 \\
- \\
-\end{array}$ & $\begin{array}{l}8 \\
8 \\
-\end{array}$ & $\begin{array}{l}\text { SP } \\
- \\
-\end{array}$ & $\begin{array}{l}- \\
-\end{array}$ & $\begin{array}{l}16 \\
8.8 \\
10\end{array}$ & $\begin{array}{l}\text { biceps } \\
\text { biceps } \\
\text { biceps }\end{array}$ \\
\hline 6 & $\begin{array}{l}16 \\
17 \\
18 \\
19\end{array}$ & $\begin{array}{l}\text { Affected } \\
\text { Asymptomatic carrier } \\
\text { Asymptomatic carrier } \\
\text { Normal control }\end{array}$ & $\begin{array}{l}27 / \mathrm{M} \\
31 / \mathrm{F} \\
35 / \mathrm{F} \\
42 / \mathrm{F}\end{array}$ & $\begin{array}{l}22 \\
\mathrm{ND} \\
- \\
-\end{array}$ & $\begin{array}{l}6 \\
6 \\
6 \\
-\end{array}$ & $\begin{array}{l}\text { FSP } \\
S \\
- \\
-\end{array}$ & $\begin{array}{l}\mathrm{NT} \\
\mathrm{T} \\
- \\
-\end{array}$ & $\begin{array}{l}262 \\
9.5 \\
9.7 \\
6.8\end{array}$ & $\begin{array}{l}\text { biceps } \\
\text { biceps } \\
\text { biceps } \\
\text { biceps }\end{array}$ \\
\hline 7 & 20 & Asymptomatic carrier & $40 / \mathrm{F}$ & - & 8 & - & - & ND & biceps \\
\hline
\end{tabular}




\begin{tabular}{|l|l|l|l|l|l|l|l|l|l|}
\hline 8 & 21 & Asymptomatic carrier & $45 / \mathrm{F}$ & - & 9 & - & - & 9.3 & biceps \\
\hline 9 & 22 & Affected & $57 / \mathrm{F}$ & ND & 6 & $\mathrm{~S}$ & $\mathrm{D}$ & 12.3 & biceps \\
\hline 10 & 23 & Asymptomatic carrier & $51 / \mathrm{F}$ & - & 8 & - & - & 5.2 & biceps \\
\hline 11 & 24 & Asymptomatic carrier & $46 / \mathrm{F}$ & - & 5 & - & - & 13.0 & biceps \\
\hline
\end{tabular}

F: face; S: shoulder girdle; P: pelvic girdle; A: ankle.

$\mathrm{N}$ : pain; T: fatigue; $\mathrm{H}$ : hearing loss; L: swallowing problem; D: depression

ND: not described 
Table 11. miRNA:mRNA predicted targeting in FSHD.

\begin{tabular}{|c|c|c|c|}
\hline miRNA:mRNA & $\begin{array}{c}\text { miRNA } \\
\text { Fold Change }\end{array}$ & $\begin{array}{c}\text { Target } \\
\text { Fold Change }\end{array}$ & MAMI score \\
\hline miR-19b : TRAK2 & 2,99 & $-4,09$ & 0,67303 \\
\hline miR-19b : B4GALNT1 & 2,99 & $-5,17$ & 0,50875 \\
\hline miR-17-3p : SMEK1 & 1,81 & $-4,14$ & 0,41443 \\
\hline miR-18a : REXO2 & 2,24 & $-3,49$ & 0,20708 \\
\hline let-7b : ATG16L1 & 1,65 & $-5,02$ & 0,11277 \\
\hline let-7c : ATG16L1 & 1,69 & $-5,02$ & 0,11277 \\
\hline let-7e : ATG16L1 & 1,77 & $-5,02$ & 0,11277 \\
\hline let-7i : ATG16L1 & 1,86 & $-5,02$ & 0,11277 \\
\hline miR-106a : ATG16L1 & 2,11 & $-5,02$ & 0,11277 \\
\hline miR-106a : EPAS1 & 2,11 & $-4,75$ & 0,11277 \\
\hline miR-106b : ATG16L1 & 3,04 & $-5,02$ & 0,11277 \\
\hline miR-106b : EPAS1 & 3,04 & $-4,75$ & 0,11277 \\
\hline miR-125a : ATOH8 & 1,83 & $-4,15$ & 0,11277 \\
\hline miR-130a : ATG16L1 & 3,02 & $-5,02$ & 0,11277 \\
\hline miR-130b : ATG16L1 & 2,03 & $-5,02$ & 0,11277 \\
\hline miR-152 : EPAS1 & 1,54 & $-4,75$ & 0,11277 \\
\hline miR-155 : PCDH9 & 4,4 & $-2,5$ & 0,11277 \\
\hline miR-15a : PCDH9 & 2,53 & $-2,5$ & 0,11277 \\
\hline miR-16 : PCDH9 & 1,77 & $-2,5$ & 0,11277 \\
\hline miR-17-5p : ATG16L1 & 2,12 & $-5,02$ & 0,11277 \\
\hline miR-17-5p : EPAS1 & 2,12 & $-4,75$ & 0,11277 \\
\hline miR-195 : PCDH9 & 2,62 & $-2,5$ & 0,11277 \\
\hline miR-199a* : RXRB & 2,83 & $-4,31$ & 0,11277 \\
\hline miR-19b : ATG16L1 & 2,99 & $-5,02$ & 0,11277 \\
\hline miR-20a : ATG16L1 & 2,13 & $-5,02$ & 0,11277 \\
\hline miR-20a : EPAS1 & 2,13 & $-4,75$ & 0,11277 \\
\hline miR-20b : ATG16L1 & 2,47 & $-5,02$ & 0,11277 \\
\hline miR-20b : EPAS1 & 2,47 & $-4,75$ & 0,11277 \\
\hline miR-93 : EPAS1 & 2,03 & $-4,75$ & 0,11277 \\
\hline let-7b : PIGV & 1,65 & $-2,76$ & 0,09432 \\
\hline let-7i : COQ9 & 1,86 & $-3,5$ & 0,09432 \\
\hline miR-140 : COQ9 & 2,31 & $-3,5$ & 0,09432 \\
\hline
\end{tabular}




\begin{tabular}{|cccc|}
\hline miR-140 : RPL13 & 2,31 & $-3,07$ & 0,09432 \\
miR-154 : COQ9 & 2,2 & $-3,5$ & 0,09432 \\
miR-199b : PIGL & 3,41 & $-5,48$ & 0,09432 \\
miR-29a : RPL13 & 2,57 & $-3,07$ & 0,09432 \\
miR-29a : ZNF346 & 2,57 & $-3,33$ & 0,09432 \\
miR-29b : RPL13 & 2,47 & $-3,07$ & 0,09432 \\
miR-29b : ZNF346 & 2,47 & $-3,33$ & 0,09432 \\
miR-34a : DIDO1 & 5,56 & $-4,19$ & 0,09432 \\
\hline
\end{tabular}

\section{Fig3}
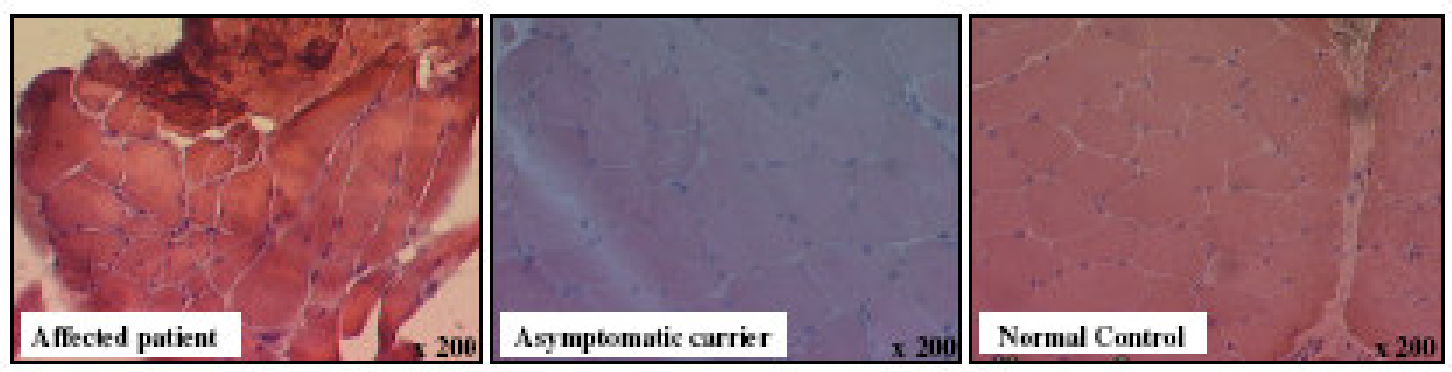


\section{CAPÍTULO IV}

\section{Análise de processamentos por "splicings" alternativos na Distrofia Muscular Fácio-escápulo-umeral (FSH)}

\section{Resultados Preliminares}

Patricia Arashiro ${ }^{1}$, Oliver King ${ }^{2}$, Iris Eisenberg ${ }^{3}$, Antonia M.P. Cerqueira ${ }^{1}$, Martha Canovas $^{1}$, Helga C.A. Silva ${ }^{4}$, Rita C.M. Pavanello ${ }^{1}$, Louis M. Kunkel ${ }^{3}$, Mayana Zatz ${ }^{1}$

${ }^{1}$ Human Genome Research Center, Department of Genetics and Evolutive Biology, Institute of Biosciences, University of São Paulo, São Paulo, 05508-090, Brazil; ${ }^{2}$ Boston Biomedical Research Institute, Watertown, MA 02472; ${ }^{3}$ Howard Hughes Medical Institute, Program in Genomics, Division of Genetics, Children's Hospital, Harvard Medical School, Boston, MA 02115; ${ }^{4}$ CEDHIMA (Brazilian Center of Study, Diagnosis, and Investigation of Malignant Hyperthermia), Dept. Surgery, Discipline of Anaesthesia, Pain and Intensive Care, University Federal of São Paulo, São Paulo, 04024-002, Brazil 


\begin{abstract}
Facioscapulohumeral muscular dystrophy (FSHD) is an autosomal dominant neuromuscular disorder that has been associated to contractions of the D4Z4 repeat array in the subtelomeric region of chromosome 4q. FSHD is characterized by progressive weakness of facial, shoulder girdle and upper arm muscles. Multiple lines of evidence, such as the lack of candidate genes and the causative association of the deletion of repetitive elements with the disease, indicate that FSHD is not the result of a classical mutation within a protein-coding gene. Instead, the genomic organization of the $4 \mathrm{q} 35$ subtelomeric region strongly argues for its role in control of gene expression. From this, one of the first proposed models to explain the molecular basis of FSHD is that D4Z4 deletion might induce abnormal transcriptional activity of the $4 \mathrm{q} 35$ genes. FRG1 gene is located on $4 \mathrm{q} 35$ at $120 \mathrm{~kb}$ distance from D4Z4. Previous studies showed that mice with intermediate or high FRG1 levels have increasing muscle pathology (Gabellini e col, 2006). Interestingly, missplicing of specific mRNAs was also observed in skeletal muscle of these mice further corroborating on the observation that FRG1 is a spliceosomal protein. Missplicing of muscle-specific mRNAs has been reported earlier in myotonic dystrophy (DM) raising the intriguing possibility of a commonality between FSHD and DM. We report here our very preliminary results from comparisons of exon-level expression profiling at the whole-genome scale from related FSHD affected patients, asymptomatic carriers and normal controls.
\end{abstract}




\section{Resumo}

A distrofia muscular fácio-escápulo-umeral (FSH) é uma doença autossômica dominante que tem sido associada a contrações das repetições D4Z4 da região subtelomérica do cromossomo 4q. FSH é caracterizada por uma fraqueza progressiva dos músculos da face, da cintura escapular e do antebraço. Várias linhas de evidências, como a ausência de genes candidatos e da associação da deleção de repetições com a doença, indicam que FSH não é resultado do mecanismo clássico da mutação em um gene que codifica uma proteína. A organização genômica da região subtelomérica do cromossomo 4q sugere que as repetições devem ter um papel no controle da expressão gênica. A partir disto, um dos modelos propostos para explicar o mecanismo molecular de FSH é de que a deleção de D4Z4 poderia induzir uma atividade transcricional anormal dos genes em 4q35. O gene FRG1 está localizado em 4q35 a 120kb de distância das repetições de D4Z4. Um estudo anterior mostrou que camundongos que expressam níveis intermediário ou alto de FRG1 apresentam doença muscular (Gabellini e col, 2006). Interessantemente, "splicings" alternativos de determinados mRNAs também foram observados no músculo esquelético destes camundongos, o que corrobora com a observação de que FRG1 é uma proteína do spliceossomo. "Splicings" alternativos de mRNAs específicos de músculo já foram descritos na distrofia miotônia (DM), o que pode indicar possíveis semelhanças entre estas duas distrofias. Nós descrevemos aqui os resultados preliminares da comparação do perfil de expressão de todos os exons entre os pacientes afetados, portadores assintomáticos e controles normais.

\section{Objetivos}

- Comparar o perfil de expressão de todos os genes e exons nas amostras de músculo de pacientes afetados, portadores assintomáticos e controles normais através da técnica de "microarray" (Human Exon 1.0 ST Array, Affymetrix);

- Comparar os resultados obtidos para a expressão gênica entre os chips U133Plus2.0 e HuEx1.0ST. 


\section{Metodologia}

\section{Extração de RNA}

A extração de RNA foi realizada de acordo com o protocolo já descrito no capítulo anterior.

\section{Microarray}

Para o Human Exon 1.0 ST Array (Affymetrix, Santa Clara, CA), seguimos o protocolo de marcação de $1 \mu \mathrm{g}$ de RNA total do "Whole Transcript (WT) Sense Target Labeling Assay Manual” (Affymetrix). Primeiramente, o RNA ribossomal (rRNA) foi reduzido da amostra de RNA total. Neste procedimento, quatro sondas de "LNA RiboMinus" biotiniladas se ligam especificamente aos rRNAs $18 \mathrm{~S}$ e 28S. Em seguida, a amostra foi incubada a $70^{\circ} \mathrm{C}$ por 5 minutos e as moléculas de rRNA foram removidas da amostra pela adição de "RiboMinus Magnetic Beads" cobertas com streptavidina. Depois, a amostra foi concentrada utilizando o kit "IVT cRNA Cleanup" (Affymetrix). Foi sintetizada a primeira e a segunda fita do cDNA a partir do RNA total com rRNA reduzido. Para IVT, foi utilizado o kit "GeneChip WT cDNA Amplification" (Affymetrix) e a purificação do cRNA com o "GeneChip Cleanup Module". A quantidade de cRNA foi determinada com o NanoDrop. 10 $\mu \mathrm{g}$ de cRNA foram utilizados para a síntese da primeira fita de cDNA. O DNA simples-fita foi purificado com o

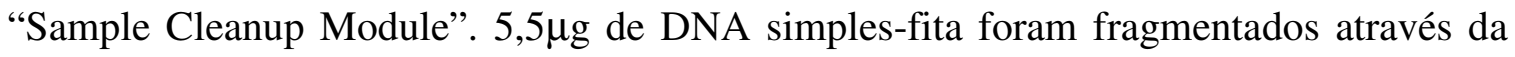
combinação de UDG ("uracil DNA glycosylase") e APE1 ("apurinic/ apyrimidinic endonuclease $1^{\prime \prime}$ ) a $37^{\circ} \mathrm{C}$ por 60 minutos e, então a $93^{\circ} \mathrm{C}$ por 2 minutos. O DNA simplesfita fragmentado foi marcado com TdT (transferase de deoxinucleotidil terminal) utilizando o kit "Affymetrix DNA Labeling Reagent". Em seguida, o DNA simples-fita foi hibridizado no chip durante $17 \mathrm{~h}$, a $45^{\circ} \mathrm{C}$ e $60 \mathrm{rpm}$. Depois disto, os chips foram lavados e corados com SAPE e as soluções de anticorpo no Fluidics Station 450 e escaneados. 


\section{Análise dos dados}

Resumidamente, a análise do perfil de expressão dos exons está sendo realizada utilizando o método de "Robust Multi-array Average" (RMA) do "Affymetrix Power Tools" (APT). O pacote "Limma" do R (www.r-project.org) está sendo utilizado para identificar os exons diferentemente expressos $(\mathrm{p}<0,001)$.

\section{Resultados preliminares e Discussão}

Um dos modelos existentes para tentar explicar o mecanismo molecular de FSH é a variegação do efeito de posição (PEV) (Winokur e col, 1994). Gabellini e cols (2002) mostraram que as deleções de D4Z4 podem causar o relaxamento da cromatina, aumentando a transcrição de genes proximais às unidades de repetição. Nesse mesmo estudo, foi mostrado que $F R G 1$, cuja proteína é um componente do spliceossomo, tem a expressão aumentada nas biópsias de músculo dos pacientes com FSH (Gabellini e cols, 2002). Recentemente, foi mostrado também que a região distal a D4Z4 pode interagir com a região promotora de $F R G 1$, especificamente em mioblastos de $\mathrm{FSH}$, dependendo do número residual de repetições de D4Z4 (Pirozhkova e col, 2008). Além disso, foi mostrado também que níveis normais de expressão de FRG1 são críticos para o desenvolvimento apropriado do músculo (Hanel e col, 2008).

Estudos têm mostrado que o "splicing" alternativo é bastante comum aproximadamente $74 \%$ de todos os genes com múltiplos exons sofrem "splicing" alternativo, o que corresponde a cerca de $50 \%$ de todos os genes humanos (Modrek \& Lee, 2002; Johnson e col, 2003). O "splicing" alternativo participa de muitas vias e processos, e o estudo destas variantes pode ajudar na compreensão de diversas doenças.

Neste estudo, que ainda está em andamento, está sendo comparado o perfil de expressão, tanto ao nível dos genes quanto dos exons, dos pacientes afetados, portadores assintomáticos e controles normais, utilizando a maioria das amostras de biópsia de músculo do estudo anterior (ver Capítulo III).

Dada a complexidade da análise desses dados e como se trata de um chip relativamente novo, a análise dos dados ainda não foi concluída. Nossos resultados

preliminares indicam que dentre os genes com maiores diferenças no "splicing", tanto 
entre os afetados e controles normais, como entre os afetados e assintomáticos, estão os relacionados com a mitocôndria. Interessantemente, já foi observada a deficiência de algumas enzimas da cadeia respiratória da mitocôndria em FSH (Slipetz e cols, 1991).

A glutationa-S-transferase, que já foi descrita anteriormente por ter a expressão, tanto do transcrito como da proteína, alterada em FSH (Winokur e col, 2003; LaoudjChenivesse e col, 2005), está entre os genes com diferenças no "splicing” nas nossas amostras de afetados relativos aos portadores assintomáticos e aos controles normais.

Reed e col (2007) estudaram o perfil de expressão de proteínas a partir das biópsias de músculo de pacientes com FSH por eletroforese bidimensional e "Western blotting" e confirmaram que a expressão da proteína CRYM (mu-cristalin) está aumentada nos pacientes afetados. Segundo os nossos resultados preliminares, os primeiros exons (região 5') de CRYM têm a expressão significativamente aumentada nos afetados relativos aos controles e assintomáticos. O fato das sondas do chip U133Plus2 serem baseados na região 3' poderia explicar porque não detectamos a diferença na expressão deste gene anteriormente (ver Capítulo III). CRYM está envolvido em diversos processos, como estresse oxidativo (Vie e col, 1997), retinopatia (Umeda e col, 2005) e deficiência auditiva (Oshima e col, 2006), características observadas em pacientes de FSH.

Nossos resultados preliminares parecem estar de acordo com alguns estudos anteriores, que dizem que os primeiros sinais de FSH podem envolver a disfunção da mitocôndria associada ao aumento do estresse oxidativo (Winokur e col, 2003; LaoudjChenivesse e col, 2005;.Celegato e col, 2006; Barro e col, 2008).

\section{Referências Bibliográficas}

Barro M, Carnac G, Flavier S, Mercier J, Vassetzky Y, Laoudj-Chenivesse D (2008) Myoblasts from affected and non affected FSHD muscles exhibit morphological differentiation defects. J Cell Mol Med. 24. 
Celegato B, Capitanio D, Pescatori M, Romualdi C, Pacchioni B, Cagnin S, Vigano A, Colantoni L, Begum S, Ricci E, Wait R, Lanfranchi G, Gelfi C (2006) Parallel protein and transcript profiles of FSHD patient muscles correlate to the D4Z4 arrangement and reveal a common impairment of slow to fast fibre differentiation and a general deregulation of MyoD-dependent genes. Proteomics 6: 5303-5321.

Gabellini D, Green MR, Tupler R (2002) Inappropriate gene activation in FSHD: a repressor complex binds a chromosomal repeat deleted in dystrophic muscle. Cell 110: 339-348.

Gabellini D, D'Antona G, Moggio M, Prelle A, Zecca C, Adami R, Angeletti B, Ciscato P, Pellegrino MA, Bottinelli R, Green MR, Tupler R (2006) Facioscapulohumeral muscular dystrophy in mice overexpressing FRG1. Nature 439: 973-977.

Hanel ML, Wuebbles RD, Jones PL (2008) Muscular dystrophy candidate gene FRG1 is critical for muscle development. Dev Dyn.

Johnson JM, Castle J, Garrett-Engele P, Kan Z, Loerch PM, Armour CD, Santos R, Schadt EE, Stoughton R, Shoemaker DD (2003) Genome-wide survey of human alternative pre-mRNA splicing with exon junction microarrays. Science 302: 2141-2144.

Laoudj-Chenivesse D, Carnac G, Bisbal C, Hugon G, Bouillot S, Desnuelle C, Vassetzky Y, Fernandez A (2005) Increased levels of adenine nucleotide translocator 1 protein and response to oxidative stress are early events in facioscapulohumeral muscular dystrophy muscle. J Mol Med 83: 216-24.

Modrek B \& Lee C (2002) A genomic view of alternative splicing. Nat Genet 30: 13-19.

Oshima A, Suzuki S, Takumi Y, Hashizume K, Abe S, Usami S (2006) CRYM mutations cause deafness through thyroid hormone binding properties in the fibrocytes of the cochlea. J Med Genet 43: e25. 
Pirozhkova I, Petrov A, Dmitriev P, Laoudj D, Lipinski M, Vassetzky Y (2008) A functional role for $4 \mathrm{qA} / \mathrm{B}$ in the structural rearrangement of the $4 \mathrm{q} 35$ region and in the regulation of FRG1 and ANT1 in facioscapulohumeral dystrophy. Plos One 3:e3389.

Reed PW, Corse AM, Porter NC, Flanigan KM, Bloch RJ (2007) Abnormal expression of mu-crystallin in facioscapulohumeral muscular dystrophy. Exp Neurol 205: 583-6.

Slipetz DM, Aprille JR, Goodyer PR, Rozen R (1991) Deficiency of complex III of the mitochondrial respiratory chain in a patient with facioscapulohumeral disease. Am J Hum Genet 48: 502-510.

Umeda S, Suzuki MT, Okamoto H, Ono F, Mizota A, Terao K, Yoshikawa Y, Tanaka Y, Iwata T (2005) Molecular composition of drusen and possible involvement of anti-retinal autoimmunity in two different forms of macular degeneration in cynomolgus monkey (Macaca fascicularis). FASEB J 19: 1683-1685.

Vie MP, Evrard C, Osty J, Breton-gilet A, Blanchet P, Pomerance M, Rouget P, Francon J, Blondeau JP (1997) Purification, molecular cloning and functional expression of the human nicodinamide-adenine dinucleotide phosphate-regulated thyroid hormone-binding protein. Mol Endocrinol 11:1728-1736.

Winokur ST, Bengtsson U, Feddersen J, Mathews KD, Weiffenbach B, Bailey H, Markovich RP, Murray JC, Wasmuth JJ, Altherr MR, Schutte BC (1994) The DNA rearrangement associated with facioscapulohumeral muscular dystrophy involves a heterochromatin associated repetitive element: implications for a role of chromatin strucuture in the pathogenesis of the disease. Chromosome Res. 2 (3): 225-34.

Winokur ST, Chen YW, Masny PS, Martin JH, Ehmsen JT, Tapscott SJ, van der Maarel SM, Hayashi Y, Flanigan KM (2003) Expression profiling of FSHD muscle supports a defect in specific stages of myogenic differentiation. Hum Mol Genet 12: 2895-907. 


\section{CAPÍtULO V}

\section{Discussão Geral e Conclusões}

A distrofia muscular fácio-escápulo-umeral (FSH) está associada à contração das repetições de D4Z4 no cromossomo 4q35. Apesar de ter sido uma das primeiras doenças musculares a ter o seu loco mapeado, não se sabe ainda a ligação entre a contração destas repetições e a doença muscular.

Vários estudos têm sugerido diversos modelos para tentar explicar o mecanismo molecular de FSH. Embora se acredita que FSH seja uma doença da regulação da transcrição, os estudos comparando a expressão gênica têm gerado diversos resultados controversos. Isso possivelmente é devido às diferentes técnicas empregadas (microarray, PCR semi-quantitativo, PCR em tempo real, etc.), fontes de RNA utilizados (tecido muscular, estágio da doença, linhagem celular, etc), bem como o processamento da amostra. Além disso, existe a questão da variabilidade individual.

Para tentar minimizar todos estes fatores, foram coletadas, para este estudo, biópsias de músculo de pessoas da mesma família para compararmos o perfil de expressão gênica por microarray. Todos os indivíduos foram atendidos no Centro de Estudos do Genoma Humano (CEGH), onde se submeteram à biópsia de músculo pela mesma equipe de médicos. Estudos têm mostrado que membros da mesma família apresentam o perfil de expressão gênica significativamente mais semelhante do que pessoas de famílias diferentes. Desta forma, ao compararmos o perfil de expressão gênica entre o afetado, assintomático e controle da mesma família, estamos minimizando as diferenças devido ao "background" genético, e provavelmente, ressaltando as diferenças relacionadas a FSH. Além disso, todas as amostras foram processadas da mesma forma, minimizando ao máximo as diferenças técnicas. Isto é, a metodologia empregada visou tentar diminuir a influência de fatores que pudessem estar comprometendo a interpretação dos resultados. Por outro lado, dada a dificuldade de se obter tecido muscular de trios (afetado, assintomático e controle) pertencentes à mesma família, outros fatores como sexo e idade, que também podem introduzir variabilidade, não puderam ser contornados. 
Os nossos resultados indicam que a deleção das repetições de D4Z4 parece ter um efeito na regulação de alguns genes in cis, tanto nos afetados quanto nos assintomáticos. No entanto, nos afetados observa-se também diferenças mais globais, em outras regiões do genoma. Nossos dados mostram, pela primeira vez, que os processos biológicos que podem estar mais afetados nos pacientes de FSH estão relacionados com a acetilação de histonas e com a modificação pós-traducional da âncora-GPI (glicosilfosfatidilinositol). A acetilação das histonas está diretamente relacionada com a conformação da cromatina, que há muito tempo se acredita estar alterada em FSH. A âncora-GPI se encontra nas proteínas da membrana das células, principalmente nas caveolae. $\mathrm{O}$ fato de terem sido observadas alterações na organização do sarcolema nos pacientes com FSH torna estas estruturas bons candidatos a serem investigados mais profundamente, a fim de se tentar entender o defeito primário responsável pelo comprometimento muscular destes pacientes.

Interessantemente, os resultados obtidos com o perfil de expressão de microRNAs (miRNAs) em FSH de um estudo anterior (Eisenberg e col, 2007) corroboram com os nossos dados. Os genes-alvos dos miRNAs que estão diferentemente expressos em FSH participam dos processos biológicos descritos acima. Isto indica que os miRNAs podem desempenhar um papel muito importante na rede regulatória em FSH. Estudos comparando a expressão dos genes de miRNAs do cromossomo $4 \mathrm{q}$ entre os afetados e os assintomáticos seriam bem interessantes a fim de se tentar entender a causa das diferenças entre estes dois grupos, uma vez que o papel dos RNAs não-codificantes em FSH têm sido pouco estudado. Nossos resultados também mostram pela primeira vez que o haplótipo "4qA161" não está associado com a patogenicidade do alelo com a deleção, sugerindo que outros fatores além da contração das repetições de D4Z4 são necessários para resultar na doença. Seria muito importante tambérm estudar a expressão dos outros genes que estão diferentemente expressos nos assintomáticos com relação aos controles, que não foram validados neste estudo, para verificar se eles podem ter algum efeito na expressividade da doença.

Os resultados preliminares da análise dos "splicings" alternativos em FSH também estão revelando dados bastante interessantes, que por ser uma forma mais robusta de se estudar a expressão gênica, oferecerá informações complementares às obtidas com os 
"arrays" tradicionais, contribuindo para melhorar o nosso entendimento a respeito desta doença.

Em resumo, apesar de haver vários estudos anteriores acerca da expressão gênica em FSH, o nosso trabalho traz uma abordagem nova. Estudamos pela primeira vez o perfil de expressão dos portadores assintomáticos e, além disso, conseguimos comparar amostras de membros da mesma família. O estudo do perfil de expressão de todos os exons do genoma, que está sendo realizado no momento também poderá revelar dados interessantes e aumentar a nossa compreensão a respeito desta doença tão intrigante. 


\section{RESUMO}

FSH é caracterizada por uma grande variabilidade clínica inter- e intrafamilial. Aproximadamente 10-20\% dos pacientes ficam em cadeira de rodas, enquanto que 20$30 \%$ dos portadores do alelo com a contração permanecem assintomáticos ou minimamente afetados. Interessantemente, estes casos parecem estar concentrados em determinadas famílias, sugerindo que algum mecanismo deve estar agindo nestes indivíduos, protegendo-os dos efeitos da doença. Para tentar explicar esta variabilidade clínica em FSH, nós comparamos o perfil de expressão gênica a partir do músculo de três membros (afetado, portador assintomático e controle normal) de cinco famílias diferentes através do microarray de expressão e de exons. Nossos resultados sugerem que a expressão dos genes no cromossomo 4q está alterada nos afetados e nos assintomáticos. Interessantemente, as alterações observadas nas amostras dos assintomáticos estão relacionadas aos genes de quemocinas, enquanto que as alterações vistas nas amostras dos afetados estão relacionadas com os genes envolvidos nos processos de acetilação de histonas e da modificação pós-traducional âncora-GPI. Além disto, os pacientes afetados e os assintomáticos compartilham o haplótipo 4qA161 e, desta forma, estes polimorfismos sozinhos não explicam a patogenicidade do alelo com a contração. Nossos

resultados corroboram com as observações anteriores de FSH deve ser causada pela desregulação transcricional de vários genes, tanto in cis como in trans, e sugerem alguns fatores potencialmente importantes na patogênese de FSH.

O estudo do perfil da expressão gênica dos portadores assintomáticos é uma abordagem nova que está revelando resultados novos e bem interessantes. Entender tal mecanismo é um grande desafio, mas que certamente levará ao desenvolvimento de novas ferramentas para o prognóstico e um possível tratamento. 


\begin{abstract}
FSHD is characterized by a great clinical inter and intrafamilial variability. Approximately $10-20 \%$ of patients eventually becoming wheelchair-bound while $20-30 \%$ with a shortened D4Z4 array, remains asymptomatic or minimally affected. Interestingly, these cases seem to be concentrated in some particular families, suggesting that some mechanism might be acting in these individuals, protecting them form the effects of the disease. In order to try to explain this clinical variability observed in FSHD, we compared the expression profiles of muscle tissue from three members (affected, asymptomatic carrier and normal control) from five unrelated FSHD families through expression and exon microarrays. Our results suggest that the expression of genes on chromosome $4 \mathrm{q}$ is altered in affected and asymptomatic individuals. Remarkably, the changes seen in asymptomatic samples are largely in products of genes encoding several chemokines, whereas the changes seen in affected samples are largely in genes governing the synthesis of GPI-linked proteins and histone acetylation. Besides this, the affected patient and related asymptomatic carrier share the 4qA161 haplotype, thus these polymorphisms by themselves do not explain the pathogenicity of the contracted allele. Together, our results support the previous evidences that FSHD may be caused by transcriptional dysregulation of multiple genes, in cis and in trans, and suggest some factors potentially important for FSHD pathogenesis.

The study of gene expression profiles from asymptomatic carriers is a novel approach that is revealing new and interesting results. Understanding such mechanisms is a great challenge, but will certainly lead to the development of new tools for prognosis and also for future treatment.
\end{abstract}




\section{REFERÊNCIAS BIBLIOGRÁFICAS}

\section{Capítulo 1}

Alexiadis V, Ballestas ME, Sanchez C, Winokur S, Vedanarayanan V, Warren M, Ehrlich M (2007) RNAPol-ChIP analysis of transcription from FSHD-linked tandem repeats and satellite DNA. Biochim.Biophys.Acta. 1769: 29-40.

Arahata K, Ishihara T, Fukunaga H, Orimo S, Lee JH, Goto K, Nonaka I (1995) Inflammatory response in facioscapulohumeral muscular dystrophy (FSHD): immunocytochemical and genetic analyses. Muscle Nerve 2: S56-S66.

Arahata K, Goto K, Yonemoto K, Fukanoshi M (1998) DNA rearrangements in Japanese patients with facioscapulohumeral muscular dystrophy (FSHD). Muscle Nerve S7: S25.

Attarian S, Malzac P, Azulay J, Pelisser J, Philip N, Pouget J (1998) Phenotype-genotype correlations studies in facioscapulohumeral muscular dystrophy. Muscle Nerve S7: S111.

Attwood JT, Yung RL, Richardson BC (2002) DNA methylation and the regulation of gene transcription. Cell Mol Life Sci 59(2): 241-257.

Awerbuch GI, Nigro MA, Wishnow R (1990) Beevor's sign and facioscapulohumeral dystrophy. Arch Neurol 47:1208-9.

Bakker E, Wijmenga C, Vossen RH, Padberg GW, Hewitt J, van der Wielen M, Rasmussen K, Frants RR (1995) The FSHD-linked locus D4F10S1 (p13E-11) on 4q35 has a homologue on 10qter. Muscle Nerve 2:S39-44.

Bakker E, van der Wielen MJ, Voorhoeve E, Ippel PF, Padberg GW, Frants RR, Wijmenga C (1996) Diagnostic, predictive, and prenatal testing for facioscapulohumeral muscular dystrophy: diagnostic approach for sporadic and familial cases. J Med Genet 33: 29-35.

Bakay M, Wang Z, Melcon G, Schiltz L, Xuan J, Zhao P, Sartorelli V, Seo J, Pegoraro E, Angelini C, Shneiderman B, Escolar D, Chen YW, Winokur ST, Pachman LM, Fan C, Mandler R, Nevo Y, Gordon E, Zhu Y, Dong Y, Wang Y, Hoffman EP (2006) Nuclear envelope dystrophies show a transcriptional fingerprint suggesting disruption of $\mathrm{Rb}$ MyoD pathways in muscle regeneration. Brain 129: 996-1013.

Bird AP (1992) The essentials of DNA methylation. Cell 70 (1): 5-8.

Bouju S, Pietu G, Le Cunff M, Cros N, Malzac P, Pellissier JF, Pons F, Leger JJ, Auffray C, Dechesne CA (1999) Exclusion of muscle specific actinin-associated LIM protein 
(ALP) gene from 4q35 facioscapulohumeral muscular dystrophy (FSHD) candidate genes. Neuromuscul Disord 9: 3-10.

Brooke MH (1977) A Clinician's View of Neuromuscular Diseases. Williams \& Wilkins.

Brouwer OF, Padberg GW, Ruys CJ, Brand R, de Laat JA, Grote JJ (1991) Hearing loss in facioscapulohumeral muscular dystrophy. Neurology 41: 1878-81.

Brouwer OF, Padberg GW, van der Ploeg RJ, Ruys CJ, Brand R. (1992) The influence of handedness on the distribution of muscular weakness of the arm in facioscapulohumeral muscular dystrophy. Brain 115: 1587-98.

Brouwer OF, Padberg GW, Wijmenga C, Frants RR (1994) Facioscapulohumeral muscular dystrophy in early childhood. Arch Neurol 51: 387-94.

Brouwer OF, Padberg GW, Bakker E, Wijmenga C, Frants RR (1995) Early onset facioscapulohumeral muscular dystrophy. Muscle Nerve S67-S72.

Bushby KM, Pollitt C, Johnson MA, Rogers MT, Chinnery PF (1998) Muscle pain as a prominent feature of facioscapulohumeral muscular dystrophy (FSHD): four illustrative case reports. Neuromuscul Disord 8: 574-9.

Butz M, Koch MC, Muller-Felber W, Lemmers RJ, Maarel van der SM, Schreiber H (2003) Facioscapulohumeral muscular dystrophy. Phenotype-genotype correlations in patients with borderline D4Z4 repeat numbers. J Neurol 250(8): 932-937.

Buzhov BT, Lemmers RJ, Tournev I, Dikova C, Kremensky I, Petrova J, Frants RR, van der Maarel SM (2005) Genetic confirmation of facioscapulohumeral muscular dystrophy in a case with complex D4Z4 rearrangements. Hum Genet 116: 262-6.

Campanero MR, Armstrong MI, Flemington EK (2000) CpG methylation as a mechanism for the regulation of E2F activity. Proc.Natl.Acad.Sci.U.S.A. 97: 6481-6486.

Carroll JE, Brooke MH (1979) Infantile facioscapulohumeral dystrophy. In: Peroneal Atrophics and Related Disorders. Serratrice G, Roux H. New York. NY. Masson Publishing USA: 305-319.

Celegato B, Capitanio D, Pescatori M, Romualdi C, Pacchioni B, Cagnin S, Vigano A, Colantoni L, Begum S, Ricci E, Wait R, Lanfranchi G, Gelfi C (2006) Parallel protein and transcript profiles of FSHD patient muscles correlate to the D4Z4 arrangement and reveal a common impairment of slow to fast fibre differentiation and a general deregulation of MyoD-dependent genes. Proteomics 6: 5303-5321.

Chen IH, Huber M, Guan T, Bubeck A, Gerace L (2006) Nuclear envelope transmembrane proteins (NETs) that are upregulated during myogenesis. BMC Cell Biol 7: 38 . 
Clapp J, Mitchell LM, Bolland DJ, Fantes J, Corcoran AE, Scotting PJ, Armour JA, Hewitt

JE (2007) Evolutionary conservation of a coding function for D4Z4, the tandem DNA repeat mutated in facioscapulohumeral muscular dystrophy. Am.J.Hum.Genet 81: 264279.

Costello JF and Plass C (2001) Methylation matters. J Med Genet 38(5): 285-303.

de Greef JC, Frants RR, van der Maarel SM (2008) Epigenetic Mechanism of Facioscapulohumeral Muscular Dystrophy. Mutat Res 647: 94-102.

Deidda G, Cacurri S, Grisanti P, Vigneti E, Piazzo N, Felicetti L (1995) Physical mapping evidence for a duplicated region on chromosome 10qter showing high homology with the facioscapulohumeral muscular dystrophy locus on chromosome 4qter. Eur J Hum Genet 3: 155-67.

Deidda G, Cacurri S, Piazzo N, Felicetti L (1996) Direct detection of 4q35 rearrangements implicated in facioscapulohumeral muscular dystrophy (FSHD). J Med Genet 33: 361-365.

Di Lazzaro V, Oliviero A, Tonali PA, Felicetti L, De Marco MB, Saturno E, Pilato F, Pescatori M, Dileone M, Pasqualetti P, Ricci E (2004) Changes in motor cortex excitability in facioscapulohumeral muscular dystrophy. Neuromuscul Disord 14: 39-45.

Dixit M, Ansseau E, Tassin A, Winokur S, Shi R, Qian H, Sauvage S, Matteotti C, van Acker AM, Leo O, Figlewicz D, Barro M, Laoudj Chenivesse D, Belayew A, Coppee F, Chen YW (2007) DUX4, a candidate gene of facioscapulohumeral muscular dystrophy, encodes a transcriptional activator of PITX1. Proc.Natl.Acad.Sci.U.S.A. 104: 1815718162.

Doerner A, Pauschinger M, Badorff A, Noutsias M, Giessen S, Schulze K, Bilger J, Rauch U, Schultheiss HP (1997) Tissue-specific transcription pattern of the adenine nucleotide translocase isoforms in humans. FEBS Lett. 414: 258-262.

Eberharter A, Becker PB (2002) Histone acetylation: a switch between repressive and permissive chromatin. Second in review series on chromatin dynamics. EMBO Rep. 3: 224-229.

Eggers S, Passos-Bueno MR, Zatz M (1993) Facioscapulohumeral muscular dystrophy: aspects of genetic counselling, acceptance of preclinical diagnosis, and fitness. J Med Genet 30: 589-592.

Ehrlich M, Jackson K, Tsumagari K, Camaño P, Lemmers RJLF (2007) Hybridization analysis of D4Z4 repeat arrays linked to FSHD. Chromossoma 116: 107-16. 
Elsheikh B, Bollman E, Peruggia M, King W, Galloway G, Kissel J (2006) Pilot trial of Diltiazem in facioscapulohumeral muscular dystrophy, American Academy of Neurology, 58th annual meeting, San Diego, P06.138.

Emery AEH. (1991) Population frequencies of inherited neuromuscular diseases: a world survey. Neuromuscul Disord 1: 19-29.

Felice KJ, North WA, Moore SA, Mathews KD (2000) FSH dystrophy 4q35 deletion in patients presenting with facial-sparing scapular myopathy. Neurology 54: 1927-31.

Felice KJ \& Moore SA (2001) Unusual clinical presentations in patients harboring the facioscapulohumeral dystrophy 4q35 deletion. Muscle Nerve 24: 352-6.

Fischle W, Wang Y, Allis CD (2003) Histone and chromatin crosstalk. Curr Opin Cell Biol 15: 172-183.

Fitzsimons RB (1999) Facioscapulohumeral muscular dystrophy. Curr Opin Neurol 12(5): 501-511.

Funakoshi M, Goto K, Arahata K (1998) Epilepsy and mental retardation in a subset of early onset 4q35-facioscapulohumeral muscular dystrophy. Neurology 50: 1791-4.

Gabellini D, Green MR, Tupler R (2002) Inappropriate gene activation in FSHD: a repressor complex binds a chromosomal repeat deleted in dystrophic muscle. Cell 110: 339-348.

Gabellini D, D'Antona G, Moggio M, Prelle A, Zecca C, Adami R, Angeletti B, Ciscato P, Pellegrino MA, Bottinelli R, Green MR, Tupler R (2006) Facioscapulohumeral muscular dystrophy in mice overexpressing FRG1. Nature 439: 973-977.

Gabriëls J, Beckers MC, Ding H, De Vriese A, Plaisance S, van der Maarel SM, Padberg GW, Frants RR, Hewitt JE, Collen D, Belayew A (1999) Nucleotide sequence of the partially deleted D4Z4 locus in a patient with FSHD identifies a putative gene within each 3.3kb element. Gene 236: 25-32.

Gelehrter TD, Collins FS, Ginsburg D (1998) Glossary. In: Principles of medical genetics. Kelly PJ (Ed) Williams \& Wilkins, Baltimore, Maryland.

Gilbert JR, Stajich JM, Speer MC, Vance JM, Stewart CS, Yamaoka LH, Samson F, Fardeau M, Potter TG, Roses AD, Pericak-Vance MA (1992) Linkage Studies in Facioscapulohumeral Muscular Dystrophy (FSHD). Am J Hum Genet 51: 424-427.

Gilbert JR, Stajich JM, Wall S, Carter SC, Qiu H, Vance JM, Stewart CS, Speer MC, Pufky J, Yamaoka LH, Rozear M, Samson F, Fardeau M, Roses AD, Pericak-Vance MA (1993) Evidence for heterogeneity in facioscapulohumeral muscular dystrophy (FSHD). Am J Hum Genet 53: 401-408. 
Goto K, Lee JH, Matsuda C, Hirabayashi K, Kojo T, Nakamura A, Mitsunaga Y, Furukawa T, Sahashi K, Arahata K (1995) DNA rearrangements in Japanese facioscapulohumeral muscular dystrophy patients: clinical correlations. Neuromuscul Disord 5: 201-8.

Goto K, Nishino I, Hayashi YK (2004) Very low penetrance in 85 Japanese families with facioscapulohumeral muscular dystrophy 1A. J Med Genet. 41: e12.

Goto K, Nishino I, Hayashi YK (2006) Rapid and accurate diagnosis of facioscapulohumeral muscular dystrophy. Neuromuscul Disord 16: 256-61.

Gottlieb B, Beitel LK, Trifiro MA (2001) Somatic mosaicism and variable expressivity. Trends Genet 17: 79-82.

Grewal PK, Carim Todd L, van der Maarel SM, Frants RR, Hewitt JE (1998) FRG1, a gene in the FSH muscular dystrophy region on human chromosome $4 \mathrm{q} 35$, is highly conserved in vertebrates and invertebrates. Gene 216: 13-19.

Griggs RC, Tawil R, Storvick D, Mendell JR, Alterr MR (1993) Genetics of facioscapulohumeral muscular dystrophy: new mutations in sporadic cases. Neurology 43: 2369-2372.

Hewitt JE, Lyle R, Clark LN, Valleley EM, Wright TJ, Wijmenga C, van Deutekom JC, Francis F, Sharpe PT, Hofker M, Frants RR, Williamson R (1994) Analysis of the tandem repeat locus D4Z4 associated with facioscapulohumeral muscular dystrophy, Hum Mol Genet. 3: 1287-1295.

Howard RS, Wiles CM, Hirsch NP, Spencer GT (1993) Respiratory involvement in primary muscle disorders: assessment and management. Q J Med 86: 175-189.

Hsu YD, Kao MC, Shyu WC, Lin JC, Huang NE, Sun HF, Yang KD, Tsao WL (1997) Application of chromosome 4q35-qter marker (pFR-1) for DNA rearrangement of facioscapulohumeral muscular dystrophy patients in Taiwan. J Neurol Sci 149: 73-79.

Jardine PE, Koch MC, Lunt PW, Maynard J, Bathke KD, Harper PS, Upadhyaya M (1994) De novo facioscapulohumeral muscular dystrophy defined by DNA probe p13E11 (D4F104S1). Arch Dis Child 71(3): 221-227.

Jensen MP, Hoffman AJ, Stoelb BL, Abresch RT, Carter GT, McDonald CM (2008) Chronic pain in persons with myotonic dystrophy and facioscapulohumeral dystrophy. Arch Phys Med Rehabil 89: 320-8.

Jiang G, Yang F, van Overveld PG, Vedanarayanan V, van der Maarel S, Ehrlich M (2003) Testing the position-effect variegation hypothesis for facioscapulohumeral 
muscular dystrophy by analysis of histone modification and gene expression in subtelomeric 4q. Hum Mol Genet 12: 2909-2921.

Johnson EW \& Braddon R (1971) Over-work weakness in facioscapulohumeral muscular dystrophy. Arch Phys Med Rehabil 52: 333-335.

Kalkman JS, Schillings ML, van der Werf SP, Padberg GW, Zwarts MJ, van Engelen BG, Bleijenberg G (2005) Experienced fatigue in facioscapulohumeral dystrophy, myotonic dystrophy, and HMSN-I. J Neurol Neurosurg Psychiatry 76: 1406-9.

Kalkman JS, Schillings ML, Zwarts MJ, van Engelen BG, Bleijenberg G (2007) Psychiatric disorders appear equally in patients with myotonic dystrophy, facioscapulohumeral dystrophy, and hereditary motor and sensory neuropathy type I. Acta Neurol Scand 115: 265-70.

Kissel JT (1999) Facioscapulohumeral dystrophy. Semin Neurol 19(1): 35-43.

Kissel JT, McDermott MP, Mendell JR, King WM, Pandya S, Griggs RC, Tawil R (2001) Randomized, double-blind, placebo-controlled trial of albuterol in facioscapulohumeral dystrophy, Neurology 57: 1434-1440.

Klinge L, Eagle M, Haggerty ID, Roberts CE, Straub V, Bushby KM (2006) Severe phenotype in infantile facioscapulohumeral muscular dystrophy. Neuromuscul Disord 16: 553-8.

Koetsier CP (1997) Pain related to FSH dystrophy: an underestimated problem? Results of an inquiry in the Netherlands. FSH Watch (Publicação da FSH Society); summer 2324.

Köhler J, Rohrig D, Bathke KD, and Koch MC (1999) Evaluation of the facioscapulohumeral muscular dystrophy (FSHD1) phenotype in correlation to the concurrence of 4q35 and 10q26 fragments. Clin Genet 55(2): 88-94.

Kowaljow V, Marcowycz A, Ansseau E, Conde CB, Sauvage S, Matteotti C, Arias C, Corona ED, Nunez NG, Leo O, Wattiez R, Figlewicz D, LaoudjChenivesse D, Belayew A, Coppee F, Rosa AL (2007) The DUX4 gene at the FSHD1A locus encodes a proapoptotic protein. Neuromuscul.Disord. 17: 611-623.

Kriwalsky MS, Deschauer M, Eckert AW, Schubert J, Zierz S (2008) Orthognathic surgery in a case of infantile facioscapulohumeral muscular dystrophy with macroglossia. Oral Maxillofac Surg 12: 195-8.

Lachner M, O'Sullivan RJ, Jenuwein T (2003) An epigenetic road map for histone lysine methylation. J Cell Sci 116: 2117-2124. 
Lanctot C, Cheutin T, Cremer M, Cavalli G, Cremer T (2007) Dynamic genome architecture in the nuclear space: regulation of gene expression in three dimensions, Nat Rev Genet 8: 104-115.

Landouzy,L. \& Dejerine,J (1885) De la myopathy atrophique progressive. Rev. Med. 5: $81-117$.

Laoudj-Chenivesse D, Carnac G, Bisbal C, Hugon G, Bouillot S, Desnuelle C, Vassetzky Y, Fernandez A (2005) Increased levels of adenine nucleotide translocator 1 protein and response to oxidative stress are early events in facioscapulohumeral muscular dystrophy muscle. J Mol Med 83: 216-224.

Lemmers RJLF, van der Maarel SM, van Deutekom JCT, van der Wielen MJR, Deidda G, Dauwerse HG, Hewitt J, Hofker M, Bakker E, Padberg GW, Frants RR (1998) Interand intrachromosomal sub-telomeric rearrangements on 4q35: implications for facioscapulohumeral muscular dystrophy (FSHD) aetiology and diagnosis. Hum Mol Genet 7: 1207-1214.

Lemmers RJLF, Kievit P, van Geel M, van der Wielen MJ, Bakker E, Padberg GW, Frants RR, van der Maarel SM (2001) Complete allele information in the diagnosis of facioscapulohumeral muscular dystrophy by triple DNA analysis. Ann Neurol 50: 816819.

Lemmers RJLF, de Kievit P, Sandkuijl L, Padberg GW, van Ommen GJ, Frants RR, van der Maarel SM (2002) Facioscapulohumeral muscular dystrophy is uniquely associated with one of the two variants of the 4q subtelomere. Nat Genet 32: 235-6.

Lemmers RJLF, Osborn M, Haaf T, Rogers M, Frants RR, Padberg GW, Cooper DN, van der Maarel SM, Upadhyaya M (2003) D4F104S1 deletion in facioscapulohumeral muscular dystrophy - Phenotype, size and detection. Neurology 61: 178-183.

Lemmers RJ, Wohlgemuth M, Frants RR, Padberg GW, Morava E, van der Maarel SM (2004) Contractions of D4Z4 on 4qB subtelomeres do not cause facioscapulohumeral muscular dystrophy. Am.J.Hum.Genet 75: 1124-1130.

Lemmers RJ, van der Wielen MJ, Bakker E, Frants RR, van der Maarel SM (2006) Rapid and accurate diagnosis of facioscapulohumeral muscular dystrophy. Neuromuscul Disord 16: 615-7.

Lemmers RJ, Wohlgemuth M, van der Gaag KJ, van der Vliet P, van Teijlingen CM, de Knijff P, Padberg GW, Frants RR, van der Maarel SM (2007) Specific sequence variations within the $4 \mathrm{q} 35$ region are associated with facioscapulohumeral muscular dystrophy. Am J Hum Genet 81: 884-894.

Li K, Warner CK, Hodge JA, Minoshima S, Kudoh J, Fukuyama R, Maekawa M, Shimizu Y, Shimizu N, Wallace DC (1989) A human muscle adenine nucleotide 
translocator gene has four exons, is located on chromosome 4, and is differentially expressed. J Biol Chem 264: 13998-14004.

Lunt PW, Compston DA, Harper PS (1989) Estimation of age dependent penetrance in facioscapulohumeral muscular dystrophy by minimizing ascertainment bias. J Med Genet 26: 755-60.

Lunt PW \& Harper PS (1991) Genetic counselling in facioscapulohumeral muscular dystrophy. J Med Genet 28(10): 655-664.

Lunt PW, Jardine PE, Koch MC, Maynard J, Osborn M, Williams M, Harper PS, Upadhyaya M (1995a) Correlation between fragment size at D4F10S1 and age at onset or at wheelchair use, with a possible generational effect, accounts for much phenotypic variation in 4q35 - facioscapulohumeral muscular dystrophy (FSHD). Hum Mol Genet 4: 951-958.

Lunt PW, Jardine PE, Koch M, Maynard J, Osborn M, Williams M, Harper PS, Upadhyaya M (1995b) Phenotypic-genotypic correlation will assist genetic counseling in 4q35-facioscapulohumeral muscular dystrophy. Muscle Nerve 2: S103-S109.

Lunt P (2000) Facioscapulohumeral muscular dystrophy: diagnostic and molecular aspects: 44-60. In: Neuromuscular diseases: from basic mechanisms to clinical management. Vol. 18. Deymeer F (Ed.) Karger, Basel.

Lunt PW, Upadhyaya M, Koch M (2004) Genotype-phenotype relationships in FSHD. Chapter 11: 151-168. In: Facioscapulohumeral muscular dystrophy: clinical medicine and molecular cell biology. Upadhyaya M, Cooper DN (Eds.) Garland Science/BIOS Scientific Publishers Limited, Abingdon.

Masny PS, Bengtsson U, Chung SA, Martin JH, van Engelen B, van der Maarel SM, Winokur ST (2004) Localization of 4q35.2 to the nuclear periphery: is FSHD a nuclear envelope disease? Hum Mol Genet 13: 1857-1871.

Mathews KD, Mills KA, Bosch EP, Ionasescu VV, Wiles KR, Buetow KH, Murray JC (1992) Linkage Localization of Facioscapulohumeral Muscular Dystrophy (FSHD) in 4q35. Am J Hum Genet 51: 428-431.

Matsumura T, Goto K, Yamanaka G, Lee JH, Zhang C, Hayashi YK, Arahata K (2002) Chromosome 4q;10q translocations: Comparison with different ethnic populations and FSHD patients. BMC Neurol 2:7.

Matsuzaka T, Sakuragawa N, Terasawa K, Kuwabara H (1986) Facioscapulohumeral dystrophy associated with mental retardation, hearing loss, and tortuosity of retinal arterioles. J Child Neurol. 1: 218-23. 
Milner EC, Lotshaw CL, Willems van Dijk K, Charmley P, Concannon P, Schroeder HW $\mathrm{Jr}$ (1989) Isolation and mapping of a polymorphic DNA sequence $\mathrm{pH} 30$ on chromosome 4. Nucleic Acids Res. 17: 4002.

Miura K, Kumagai T, Matsumoto A, Iriyama E, Watanabe K, Goto K, Arahata K (1998) Two cases of chromosome 4q35-linked early onset facioscapulohumeral muscular dystrophy with mental retardation and epilepsy. Neuropediatrics 29: 239-41.

Nakagawa M, Matsuzaki T, Higuchi I, Fukunaga H, Inui T, Nagamitsu S, Yamada H, Arimura K, Osame M (1997) Facioscapulohumeral muscular dystrophy: clinical diversity and genetic abnormalities in Japanese patients. Intern Med. 36: 333-9.

Olsen DB, Gideon P, Jeppesen TD, Vissing J (2006) Leg muscle involvement in facioscapulohumeral muscular dystrophy assessed by MRI. J Neurol 253: 1437-41.

Osborne RJ, Welle S, Venance SL, Thornton CA, Tawil R (2007) Expression profile of FSHD supports a link between retinal vasculopathy and muscular dystrophy. Neurology 68: 569-577.

Padberg GW (1982): Facioscapulohumeral disease; Ph.D. thesis, The Netherlands, Intercontinental Graphics, 243 pages.

Padberg GW, Brouwer OF, de Keizer RJ, Dijkman G, Wijmenga C, Grote JJ, Frants RR (1995) On the significance of retinal vascular disease and hearing loss in facioscapulohumeral muscular dystrophy. Muscle Nerve S73-80.

Padberg GW, Lunt PW, Koch M, Fardeau M (1997) Facioscapulohumeral muscular dystrophy. Chapter 3: 9-15. In: Diagnostic criteria for neuromuscular disorders. Emery AEH (Ed.) ENMC, Baarn.

Padberg GW (1998) Fascioscapulohumeral muscular dystrophy. Chapter 5: 105-121. In: Neuromuscular disorders: clinical and molecular genetics. Emery AEH (Ed.) John Wiley \& Sons Ltd, Chichester.

Padberg GW (2004). Facioscapulohumeral muscular dystrophy: a clinician's experience. In: FSHD Facioscapulohumeral muscular dystrophy: Clinical Medicine and Molecular Cell Biology. Upadhyaya M, Cooper DN. BIOS Scientific Publishers London and New York, pp 41-54.

Pandya S, King WM, Tawil R (2008) Facioscapulohumeral dystrophy. Phys Ther 88: 105-13.

Pashmforoush M, Pomies P, Peterson KL, Kubalak S, Ross J, Hefti A, Aebi U, Beckerle MC, Chien KR (2001) Adult mice deficient in actinin-associated LIM domain protein reveal a developmental pathway for right ventricular cardiomyopathy. Nat Med 7: 591597. 
Passos-Bueno MR, Wijmenga C, Takata RE, Marie SK, Vainzof M, Pavanello RC, Hewitt JE, Bakker E, Carvalho A, Akiyama J, Frants RR, Zatz M (1993) No evidence of genetic heterogeneity in Brazilian facioscapulohumeral muscular dystrophy families (FSHD) with 4q markers. Hum Mol Genet 2: 557-62.

Peterson CL, Laniel MA (2004) Histones and histone modifications. Curr Biol 14: R546R551.

Petrov A, Pirozhkova I, Carnac G, Laoudj D, Lipinski M, Vassetzky YS (2006) Chromatin loop domain organization within the $4 \mathrm{q} 35$ locus in facioscapulohumeral dystrophy patients versus normal human myoblasts. Proc.Natl.Acad.Sci.U.S.A. 103: 6982-6987.

Petrov A, Allinne J, Pirozhkova I, Laoudj D, Lipinski M, Vassetzky YS (2008) A nuclear matrix attachement site in the 4q35 locus has an enhancer-blocking activity in vivo: implications for the facio-escapulo-humeral dystrophy. Genome Res 18: 39-45.

Randolph-Anderson BL, Stajich JM, Graham FL, Pericak-Vance MA, Speer MC, Gilbert JR (2002) Evidence consistent with linkage to 15q of a non-chromosome 4 linked FSHD family. Am J Hum Genet 71:S530.

Razin SV, Iarovaia OV, Sjakste N, Sjakste T, Bagdoniene L, Rynditch AV, Eivazova ER, Lipinski M, Vassetzky YS (2007) Chromatin domains and regulation of transcription. J Mol Biol. 369: 597-607.

Ricci E, Galluzzi G, Deidda G, Cacurri S, Colantoni L, Merico B, Piazzo N, Servidei S, Vigneti E, Pasceri V, Silvestri G (1999) Progress in the molecular diagnosis of facioscapulohumeral muscular dystrophy and correlation between the number of KpnI repeats at the 4q35 locus and clinical phenotype. Ann Neurol 45(6): 751-757.

Richardson B (2003) Impact of aging on DNA methylation. Ageing Res Rev 2(3): 245261.

Rijkers T, Deidda G, van Koningsbruggen S, van Geel M, Lemmers RJ, van Deutekom JC, Figlewicz D, Hewitt JE, Padberg GW, Frants RR, van der Maarel SM (2004) FRG2, an FSHD candidate gene, is transcriptionally upregulated in differentiating primary myoblast cultures of FSHD patients. J Med Genet 41: 826-836.

Rogers MT (2004a). Facioscapulohumeral muscular dystrophy: historical background and literature review. In: FSHD Facioscapulohumeral muscular dystrophy: Clinical Medicine and Molecular Cell Biology. Upadhyaya M, Cooper DN. BIOS Scientific Publishers London and New York, pp 17-40.

Rogers MT, Sewry CA, Upadhyaya M (2004b) Histological, immunocytochemical, molecular and ultrastructural characteristics of FSHD muscle. Chapter 18: 277-298. In: 
Facioscapulohumeral muscular dystrophy: clinical medicine and molecular cell biology. Upadhyaya M, Cooper DN (Eds.) Garland Science/BIOS Scientific Publishers Limited, Abingdon.

Rose MR and Tawil R (2004) Drug treatment for facioscapulohumeral muscular dystrophy, Cochrane Database Syst. Rev. 2.

Saito Y, Miyashita S, Yokoyama A, Komaki H, Seki A, Maegaki Y, Ohno K (2007) Facioscapulohumeral muscular dystrophy with severe mental retardation and epilepsy. Brain Dev. 29: 231-3.

Sarfarazi M, Wijmenga C, Upadhyaya M, Weiffenbach B, Hyser C, Mathews K, Murray J, Gilbert J, Pericak-Vance M, Lunt P, Frants RR, Jacobsen S, Harper PS, Padberg GW (1992) Regional Mapping of Facioscapulohumeral Muscular Dystrophy Gene on 4q35: Combined Analysis of an International Consortium. Am J Hum Genet 51: 396-403.

Shahrizaila N \& Wills AJ (2005) Significance of Beevor's sign in facioscapulohumeral dystrophy and other neuromuscular diseases. J Neurol Neurosurg Psychiatry 76: 869-70.

Singal R and Ginder GD (1999) DNA methylation. Blood 93(12): 4059-4070.

Stepien G, Torroni A, Chung AB, Hodge JA, Wallace DC (1992) Differential expression of adenine nucleotide translocator isoforms in mammalian tissues and during muscle cell differentiation. J Biol Chem 267: 14592-14597.

Strahl BD, Allis CD (2000) The language of covalent histone modifications. Nature 403: 41-45.

Tam R, Smith KP, Lawrence JB (2004) The 4q subtelomere harboring the FSHD locus is specifically anchored with peripheral heterochromatin unlike most human telomeres. J Cell Biol 167: 269-279.

Tawil R, Forrester J, Griggs RC, Mendell J, Kissel J, McDermott M, King W, Weiffenbach B, Figlewicz D (1996) Evidence for anticipation and association of deletion size with severity in facioscapulohumeral muscular dystrophy. The FSH-DY Group. Ann Neurol 39(6): 744-748.

Tawil R, McDermott MP, Pandya S, King W, Kissel J, Mendell JR, Griggs RC (1997) A pilot trial of prednisone in facioscapulohumeral muscular dystrophy. FSHDY Group, Neurology 48: 46-49.

Thomas NS, Wiseman K, Spurlock G, MacDonald M, Üstek D, Upadhyaya M (2007) A large patient study confirming that facioscapulohumeral muscular dystrophy (FSHD) disease expression is almost exclusively associated with an FSHD locus located on a 4qA-defined 4qter subtelomere. J Med Genet 44: 215-218. 
Tonini MM, Passos-BuenoMR, Cerqueira A, Matioli SR, Pavanello R, Zatz M (2004) Asymptomatic carriers and gender differences in facioscapulohumeral muscular dystrophy (FSHD). Neuromusc Disord 14(1): 33-38.

Tonini MMO, Lemmers RJLF, Pavanello RCM, Cerqueira AMP, Frants RR, van der Maarel SM, Zatz M (2006) Equal proportions of affected cells in muscle and blood of a mosaic carrier of facioscapulohumeral muscular dystrophy. Hum Genet 119: 23-28.

Tsien F, Sun B, Hopkins NE, Vedanarayanan V, Figlewicz D, Winokur S, Ehrlich M (2001) Methylation of the FSHD syndromelinked subtelomeric repeat in normal and FSHD cell cultures and tissues. Mol Genet Metab 74: 322-331.

Tsumagari K, Qi L, Jackson K, Shao C, Lacey M, Sowden J, Tawil R, Vedanarayanan V, Ehrlich M (2008) Epigenetics of a tandem DNA repeat: chromatin DNaseI sensitivity and opposite methylation changes in cancers. Nucleic Acids Res 1-12.

Tupler R, Berardinelli A, Barbierato L, Frants R, Hewitt JE, Lanzi G, Maraschio P, Tiepolo L (1996) Monosomy of distal 4q does not cause facioscapulohumeral muscular dystrophy. J Med Genet 33(5): 366-370.

Tyler FH \& Stephens FE (1950) Studies in disorders of muscle. II: clinical manifestations and inheritance of facioscapulohumeral dystrophy in a large family. Ann Intern Med 32: 640-660.

Upadhyaya M, Lunt PW, Sarfarazi M, Broadhead W, Daniels J, Owen M, Harper PS (1990) DNA marker applicable to presymptomatic and prenatal diagnosis of facioscapulohumeral disease. Lancet 336: 1320-1.

Upadhyaya M, Lunt PW, Sarfarazi M, Broadhead W, Daniels J, Owen M, Harper PS (1991) A closely linked DNA marker for facioscapulohumeral disease on chromosome 4q. J Med Genet 28: 665-71.

Upadhyaya M, Jardine P, Maynard J, Farnham J, Sarfarazi M, Wijmenga C, Hewitt JE, Frants RR, Harper PS, Lunt PW (1993) Molecular analysis of British facioscapulohumeral dystrophy families for $4 \mathrm{q}$ DNA rearrangements. Hum Mol Genet 2: 981-7.

Upadhyaya M, Maynard J, Rogers MT, Lunt PW, Jardine P, Ravine D, Harper OS (1997) Improved molecular diagnosis of facioscapulohumeral muscular dystrophy (FSHD): validation of the differential double digestion for FSHD. J Med Genet 34: 476-9.

van der Kooi AJ, Visser MC, Rosenberg N, van den Berg-Vos R, Wokke JH, Bakker E, de Visser M (2000) Extension of the clinical range of facioscapulohumeral dystrophy: report of six cases. J Neurol Neurosurg Psychiatry 69(1): 114-6. 
van der Kooi EL, Vogels OJ, van Asseldonk RJ, Lindeman E, Hendriks JC, Wohlgemuth M, van der Maarel SM, Padberg GW (2004) Strength training and albuterol in facioscapulohumeral muscular dystrophy. Neurology 63: 702-708.

van der Kooi EL, de Greef JC, Wohlgemuth M, Frants RR, van Asseldonk RJ, Blom HJ, van Engelen BG, van der Maarel SM, Padberg GW (2006) No effect of folic acid and methionine supplementation on D4Z4 methylation in patients with facioscapulohumeral muscular dystrophy. Neuromuscul Disord 16: 766-9.

van der Maarel SM, Deidda G, Lemmers RJLF, van Overveld PG, van der Wielen M, Hewitt JE, Sandkuijl L, Bakker B, van Ommen GJ, Padberg GW, Frants RR (2000) De novo facioscapulohumeral muscular dystrophy: frequent somatic mosaicism, sexdependent phenotype, and the role of mitotic transchromosomal repeat interaction between chromosomes 4 and 10. Am J Hum Genet 66: 26-35.

van Deutekom JCT (1996a) Towards the molecular mechanism of facioscapulohumeral muscular dystrophy. Tese de doutorado, Leiden University, Leiden (Holanda)

van Deutekom JCT, Bakker E, Lemmers RJLF, van der Wielen M, Bik E, Hofker MH, Padberg GW \& Frants RR (1996b): Evidence for subtelomeric exchange of $3.3 \mathrm{~kb}$ tandemly repeated units between chromosomes 4q35 and 10q26: implications for genetic counselling and etiology of FSHD1.Hum Mol Genet. 5(12):1997-2003.

van Deutekom JCT, Lemmers RJLF, Grewal PK, van Geel, Romberg S, Dauwerse HG, Wright TJ, Padberg GW, Hofker MH, Hewitt JE, Frants RR (1996c) Identification of the first gene (FRG1) from the FSHD region on human chromosome 4q35. Hum Mol Genet 5: 581-590.

van Geel M, Dickson MC, Beck AF, Bolland DJ, Frants RR, van der Maarel SM, de Jong PJ, Hewitt JE (2002) Genomic analysis of human chromosome 10q and 4q telomeres suggests a common origin. Genomics 79: 210-7.

van Koningsbruggen S, Dirks RW, Mommaas AM, Onderwater JJ, Deidda G, Padberg GW, Frants RR, van der Maarel SM (2004) FRG1P is localised in the nucleolus, Cajal bodies, and speckles. J Med Genet 41.

van Overveld PGM, Lemmers RJLF, Deidda G, Sandkuijl L, Padberg GW, Frants RR \& van der Maarel S (2000): Interchromosomal repeat array interactions between chromosomes 4 and 10: a model for subtelomeric plasticity. Human Molecular Genetics 9 (19): 2879-2884.

van Overveld PG, Lemmers RJ, Sandkuijl LA, Enthoven L, Winokur ST, Bakels F, Padberg GW, van Ommen GJ, Frants RR, van der Maarel SM (2003) Hypomethylation of D4Z4 in 4q-linked and non-4q-linked facioscapulohumeral muscular dystrophy. Nat Genet 35: 315-317. 
van Overveld PG, Enthoven L, Ricci E, Rossi M, Felicetti L, Jeanpierre M, Winokur ST, Frants RR, Padberg GW, van der Maarel SM (2005) Variable hypomethylation of D4Z4 in facioscapulohumeral muscular dystrophy. Ann Neurol 58: 569-576.

Walrafen P, Nguyen K, Vovan C, Vannier A, Dufrane N, Bernard R, Bensimon A, Lévy N (2008) Direct and Simultaneous Visualization of D4Z4 Arrays on Distinct 4qA, 4qB and 10q Combed Alleles: Implications for FSHD Diagnosis and Physiopathology. FSHD International Research Consortium, 11 November 2008, Philadelphia, PA.

Walter MC, Lochmuller H, Reilich P, Klopstock T, Huber R, Hartard M, Hennig M, Pongratz D, Muller-Felber M (2000) Creatine monohydrate in muscular dystrophies: A double-blind, placebo-controlled clinical study. Neurology 54: 1848-1850.

Weiffenbach B, Bagley R, Falls K, Hyser C, Storvick D, Jacobsen SJ, Schultz P, Mendell J, van Dijk KW, Milner EC, Griggs R (1992) Linkage Analyses of Five Chromosome 4 Markers Localizes the Facioscapulohumeral Muscular Dystrophy (FSHD) Gene to Distal 4q35. Am J Hum Genet 51: 416-423.

Weiffenbach B, Dubois J, Storvick D, Tawil R, Jacobsen SJ, Gilbert J, Wijmenga C, Mendell JR, Winokur S, Altherr MR, Schultz P, Olandt S, Frants RR, Pericak-Vance M, Griggs RC (1993) Mapping the facioscapulohumeral muscular dystrophy gene is complicated by chromosome 4q35 recombination events. Nature Genet 4: 165-169.

Wijmenga C, Frants RR, Brouwer OF, Moerer P, Weber JL, Padberg GW (1990) Location of facioscapulohumeral muscular dystrophy gene on chromosome 4. Lancet 336: $651-3$.

Wijmenga C, Padberg GW, Moerer P, Wiegant J, Liem L, Brouwer OF, Milner EC, Weber JL, van Ommen GB, Sandkuyl LA, Frants RR (1991) Mapping of facioscapulohumeral muscular dystrophy gene to chromosome 4q35-qter by multipoint linkage analysis and in situ hybridization. Genomics 9: 570-5.

Wijmenga C, Hewitt JE, Sandkuijl LA, Clark LN, Wright TJ, Dauwerse JG, Gruter AM, Hofker MH, Moerer P, Williamson R, van Ommen GJ, Padberg GW, Frants RR (1992a) Chromosome 4q DNA rearrangements associated with facioscapulohumeral muscular dystrophy. Nature Genet 2: 26-30.

Wijmenga C, Brouwer OF, Padberg GW, Frants RR (1992b) Transmission of a de novo mutation associated with facioscapulohumeral muscular dystrophy. Lancet 340: 985-986.

Wijmenga C, Wright TJ, Baan MJ, Padberg GW, Williamson R, van Ommen GJ, Hewitt JE, Hofker MH, Frants RR (1993a) Physical mapping and YAC-cloning connects four genetically distinct 4qter loci (D4S163, D4S139, D4F35S1 and D4F104S1) in the FSHD gene-region. Hum Mol Genet 2: 1667-72. 
Wijmenga C, Frants RR, Hewitt JE, van Deutekom JC, van Geel M, Wright TJ, Padberg GW, Hofker MH, van Ommen GJ (1993b) Molecular genetics of facioscapulohumeral muscular dystrophy. Neuromuscul Disord 3: 487-91.

Wijmenga C, van Deutekom JC, Hewitt JE, Padberg GW, van Ommen GB, Hofker MH, Frants RR (1994) Pulsed-field gel electrophoresis of the D4F10S1 locus reveals the size and the parental origin of the Facioscapulohumeral Muscular Dystrophy (FSHD) associated deletions. Genomics 19: 21-26.

Winokur ST, Chen YW, Masny PS, Martin JH, Ehmsen JT, Tapscott SJ, van der Maarel SM, Hayashi Y, Flanigan KM (2003) Expression profiling of FSHD muscle supports a defect in specific stages of myogenic differentiation. Hum Mol Genet 12: 2895-2907.

Wohlgemuth M, van der Kooi EL, van Kesteren RG, van der Maarel SM, Padberg GW (2004) Ventilatory support in facioscapulohumeral muscular dystrophy. Neurology 63: 176-8.

Wohlgemuth M, de Swart BJ, Kalf JG, Joosten FB, van der Vliet AM, Padberg GW (2006) Dysphagia in facioscapulohumeral muscular dystrophy. Neurology 66: 1926-8.

Worman HJ, Bonne G (2007) Laminopathies: a wide spectrum of human diseases. Exp Cell Res 313: 2121-2133.

Wright TJ, Wijmenga C, Clark LN, Frants RR, Williamson R, Hewitt JE (1993) Fine mapping of the FSHD gene region orientates the rearranged fragment detected by the probe p13E-11. Hum Mol Genet 2: 1673-8.

Wu ZY, Wang ZQ, Murong SX, Wang N (2004) FSHD in Chinese population: characteristics of translocation and genotype-phenotype correlation. Neurology 63(3): 581-583.

Xia H, Winokur ST, Kuo WL, Altherr MR, Bredt DS (1997) Actinin-associated LIM protein: identification of a domain interaction between PDZ and spectrin-like repeat motifs. J Cell Biol 139: 507-515.

Yang F, Shao C, Vedanarayanan V, Ehrlich M (2004) Cytogenetic and immuno-FISH analysis of the $4 \mathrm{q}$ subtelomeric region, which is associated with facioscapulohumeral muscular dystrophy. Chromosoma 112: 350-359.

Yasukohchi S, Yagi Y, Akabane T, Terauchi A, Tamagawa K, Mizuno Y (1988) Facioscapulohumeral dystrophy associated with sensorineural hearing loss, tortuosity of retinal arterioles, and an early onset and rapid progression of respiratory failure. Brain Dev 10: 319-24.

Zatz M, Marie SK, Passos-Bueno MR, Vainzof M, Campiotto S, Cerqueira A, Wijmenga C, Padberg G, Frants RR (1995) High proportion of new mutations and possible 
anticipation in Brazilian facioscapulohumeral muscular dystrophy families. Am J Hum Genet 56: 99-105.

Zatz M, Marie SK, Cerqueira A, Vainzof M, Pavanello RC, Passos-Bueno MR (1998) The facioscapulohumeral muscular dystrophy (FSHD1) gene affects males more severely and more frequently than females. Am J Med Genet 77: 155-61.

Zhang Y, Forner J, Fournet S, Jeanpierre M (2001) Improved characterization of FSHD mutations. Ann Genet 44: 105-110.

Zhou J, Berger SL (2004) Good fences make good neighbors: barrier elements and genomic regulation. Mol Cell 16: 500-502.

\section{Capítulo 2}

Miller S, Dykes D, Polesky HF (1988): A simple salting out procedure for extracting DNA from human nucleated cells. Nucleic Acid Research. 16:1215. 


\section{ANEXO}

Termo de consentimento para biópsia de músculo 


\section{Formulário de Consentimento para Pesquisa Genética}

\section{Projeto: "ESTUDO DE GENES E A VARIABILIDADE DO QUADRO CLÍNICO DE PACIENTES COM DISTROFIA MUSCULAR FÁCIO- ESCÁPULO-UMERAL (FSH)"}

\section{- Formulário de Consentimento para Pesquisa Genética:}

$\mathrm{Eu}$ confirmo que foram explicados os objetivos deste estudo, assim como os procedimentos dos exames e seus riscos. Entendo que minha participação é voluntária e que posso interrompê-la a qualquer momento. Estando de acordo em participar desta pesquisa científica concordo em ter meu sangue coletado para fins de diagnóstico e pesquisa. Concordo ainda em me submeter a uma biópsia muscular para fins exclusivamente de pesquisa. Este procedimento consiste em uma pequena cirurgia, realizada sob anestesia local que resulta em uma pequena cicatriz permanente.

Nome do participante:

RG:

Idade:

Sexo:

Endereço:

Participante ou responsável

Médico responsável: Dr. Ivo Pavanello Filho (CRM: 36834 - Tel: 328

Pesquisadora responsável: Patricia Arashiro (Tel: 3091 7966) 
- Consentimento para Registro Fotográfico:

O material fotográfico fará parte do prontuário do paciente e não será exposto ou publicado sem seu consentimento.

( ) Eu concordo com o registro fotográfico para arquivo no prontuário apenas, sem que ele seja exposto ou publicado de forma alguma.

( ) Eu concordo com o registro fotográfico para arquivo no prontuário e concordo que esse material seja utilizado em publicações científicas, sem que meu nome seja mencionado.

Assinatura do participante ou responsável: 